\title{
Sokağın, Meydanın, Şehirlilerin Resmi: On Altıncı Yüzyıl Sonu İstanbul'unda Mekân Pratikleri ve Görselliğin Dönüşümü
}

\author{
Çiğgdem Kafescioğlu*
}

\begin{abstract}
Özet
Bu makale on altıncı yüzyıl sonlarında Osmanlı resimli yazmalarında yer almaya başlayan sokak ve meydan odaklı İstanbul resimleri, aynı senelerde üretilen bir şehir manzarası ve özellikle İntizami Sûrnâme'sinin resimli kopyası (1588) üzerinde durarak, kentsel mekânlar, mekân pratikleri ve şehirlilik temsilleri arasındaki bağlantıları araştırıyor. İstanbul'u bir erken modern dönem başkenti ve metropolü olarak ele alarak, şehir ve şehirlilik tahayyüllerini üç ana konu üzerinden inceliyor: mekân pratiklerine bağlı olarak oluşan ve dönüşen görme biçimleri, göze/ görmeye dair lügatin özellikleri ve bu lügatin mekân pratikleri ile bağlantıları; yeni bir şehirli zümrenin oluşmasına koşut olarak yeni türden kamusallıkların ve çok sesli temsil biçimlerinin ortaya çıkması; bu dönemin siyasi dinamiklerinin şehrin kamusal alanlarını müzakere ve muhalefet mekânları haline getirmesi ve bu yeni dinamiğin görsel temsildeki yansımaları.
\end{abstract}

Anahtar kelimeler: İstanbul, Atmeydanı, Divanyolu, Sûrnâme, meydan, kamusal mekân, mekân pratikleri, görsellik, görsel temsil, resimli tarih yazmaları, on altıncı yüzyıl, Osmanlı

Picturing the Streets, the Square, and the Burghers of Istanbul: Spatial Practices and Shifts in Visuality in the Late Sixteenth-Century

\begin{abstract}
Exploring intersections of spaces, practices, and representations of urbanity and the city in late sixteenth-century Istanbul, this paper traces the emergence of the main public square and the streets of the Ottoman capital as the main site for a set of new themes in illustrated court histories and chronicles. It focuses particularly on the illustrated copy of Intizami's Sûrnâme (1588) along with other texts and images, including a city view from these years. The paper considers new visual imaginings of city and urbanity in light of three issues that resonate with the history of early modern Istanbul: the modalities and the lexicon of vision as they took shape parallel to the changing spatial practices; the emergence of polyphonic forms of representation and new publicities concomitant to the emergence of a new urban public; and the pictorial and textual reflections of the conflicted political environment that turned the city's public spaces into arenas of contestation and conflict.
\end{abstract}

Keywords: Istanbul, Atmeydanı (Hippodrome), Divanyolu, Sûrnâme, meydan, public square, public space, spatial practice, visuality, visual representation, illustrated court histories, sixteenth century, Ottoman

\footnotetext{
"Boğaziçi Üniversitesi, kafescio@boun.edu.tr

Bu yazıyı tarihin ve tarihyazımının kamusal boyutları üzerine de düşünen ve çalıșan, vakitsiz kaybettiğimiz dostum ve meslektaşım Vangelis Kechriotis'in anısına ithaf ediyorum. Bu metni farklı aşamalarında okuyan veya konuşmalarımı dinleyen, fikirlerini benimle paylaşan Ahmet Ersoy, Derin Terzioğlu, Emine Fetvacı, Selim S. Kuru, Shirine Hamadeh, Sussan Babaie ve yazıyı YILLIK için değerlendiren iki anonim okura içten teşekkürlerimi sunarım. Bu yazının ilk taslağını 2014 senesinde Harvard Üniversitesi Radcliffe ileri Çalışmalar Enstitüsü'nde (Radcliffe Institute for Advanced Study), "erken modern dönemde Osmanlı dünyasında şehir tahayyülleri" konulu kitap projem çerçevesinde tamamladım; bu kurumda, 2014'te Pera Müzesi’nde düzenlenen "SSehri Hayal Etmek: Sanattan Hayata İstanbul Temsilleri" sempozyumunda, Courtauld Institute of Art, UCLA, Beyrut Amerikan Üniversitesi, İstanbul İsveç Araştırma Enstitüsü'nde ve Sofya Illeri Araştırmalar Enstitüsü’nde sundum. Bu konuşmalar sırasında fikirlerini ve gözlemlerini paylaşan meslektaşlarıma, "Şehri Hayal Etmek" sempozyumunu düzenleyen Olcay Akyıldız ve Zeynep Uysal'a müteşekkirim. Bu çalışmada üzerinde durduğum yazmaları Topkapı Sarayı Müzesi Müdürlüğü’nün izni ile inceledim. Sûrnâme yazmasının durumu konusunda gözlemlerini benimle paylaşan Zeynep Atbaş ve Serpil Bağcı'ya içtenlikle teşekkür ederim.
} 
1585 senesi civarında, bir Divan-1 Hümayun kâtibinden, üç sene kadar önce tamamlayarak saraya sunduğu bir eseri tashih edip genişletmesi istendi. Yeniden yazılacak olan kitap, kendisine İntizami mahlasını uygun gören yazarın dönemin padişahı Ill. Murad'ın (15741595) oğlu şehzade Mehmed'in sünnet düğünü hakkında kaleme aldığı Sûrnâme idi. Buyruğa göre İntizami dügün sırasında yazdığı Sûrnâme'yi o şekilde tashih edecek ve genişletecekti ki, her ehl-i hırefin şöhreti ve güzelliği tafsil edilecek, bu anlatının her bir kısmı bir "meclis" teşkil edecek ve her meclis İstanbul'un Atmeydanı'nı merkez alan bir resme konu olacaktı: "Her hüner ehli neyle gelmiş ise / Pîşesinde ne fenni kulmış ise / Hep firâden ola birer meclis / Nakş ola 'aynı ile her meclis / Her birinde hem Atmeydanı / Her biri yazlla vü her yanı." Bu talebin sonucu, bütünlüğüne değilse de bazı imgelerine fazlasıyla aşina olduğumuz bir kitap: bu, bir süre sonra aarem ağaları Mehmed Ağa ve Zeyrek Ağa aracılığı ile III. Murad’a sunulan, "iki yüz elli 'aded her safhatı" meclislerle bezenmiş, başlık sayfasını kaybetmiş olduğundan araştırmacıların diğer nüshalarına atıfla Sûrnâme-i Humâyûn olarak adlandırdıkları düğün kitabıdır. ${ }^{2}$ Bazı varakları eksik, cildi değişmiş, bazı sayfa sıralamaları bozulmuş olsa da, ünlü Sûrnâme yazması İntizami'nin anlatısıyla örtüşür: Dügünün gün gün anlatımında her bir meclis, mekânı Atmeydanı olan bir resmin konusudur. ${ }^{3}$

İstanbul'un en merkezi meydanı, seyir ve temaşanın, siyasetin ve adaletin yeri, şehrin kamusal mekânlarından biri ve aynı zamanda saray için bir tören alanı olan Atmeydanı'nın, bu yeniden yazılması ısmarlanan kitabın merkezine yerleştirilmesini üzerinde durmaya değer buluyorum; çünkü bu, yine İstanbul'un sokakları ve özellikle Atmeydanı'na odaklanmış, saraylıları ve şehirlileri şehrin kamusal alanlarında resmeden (yine, sık sık karşılaştığımız için ne derece yenilikçi oldukları üzerinde pek durmadığımız) bir dizi imgenin birdenbire ortaya çıktığı yıllara

1 İntizami Sûrnâme'sinin bir yazmasının derkenarında bulunan ve kitabın yazım aşamalarının detaylarını içeren manzum otobiyografik anlatı; Mehmet Arslan, Osmanlı Saray Düğünleri ve Senlikleri 2: Intizâmi Surnâmesi (Surnâme-i Humâyûn) (İstanbul: Sarayburnu Kitaplığı, 2009), 44-45. Kitabın ehl-i hirefe göre meclislere ayrılarak tekrar yazılmasının bazı detayları Sûrnâme'nin Topkapı Sarayı Kütüphanesi'nde bulunan resimli yazmasında da bulunur; İntizami, Sûrnâme-i Humâyûn, Topkapı Sarayı Müzesi Kütüphanesi, H 1344, 428b-430a; Arslan, Intizâmi, 487-488. Bu çalışmada İntizami Sûrnâme'sinin resimli kopyasına referanslar Topkap1 Sarayı Müzesi Kütüphanesi Hazine 1344 (bundan sonra TSMK H 1344) numaralı yazmaya, ve Mehmet Arslan'1n Topkap1 ve Süleymaniye Kütüphanesi nüshalarını içeren yayınına yapılmaktadır. Arslan'ın transkripsiyonunda TSMK H 1344'ün varak numaralandırması resimler hariç tutularak yapılmıştır; burada yazmada bulunan varak numaralandırmasını kullanıyorum. Eserin nüshaları için bkz. dipnot 3 .

2 Topkapı Sarayı Müzesi Kütüphanesi’nde bulunan Hazine 1344 numaralı yazma günümüze 432 varak ve 205 ’i çift varak üzerine yerlestirilmis 224 resimle ulaşmıștır. Kitap 1588 senesi sonlarında tamamlanmıstır: 15 Zilhicce 996 (5 Kasım 1588) tarihli bir ruus kaydında tamamlanmış olan "Sûr-ı Humâyûnnâme" için çalışmış olan ve yapımı devam eden Hünernâme üzerinde de çalışmakta olan katip, nakkaş, müzehhip ve mücellitlere, Şehnameci Lokman'ın arzı üzerine verilecek terakkiler kaydedilmiştir; bkz. BOA, KK.d 250, vrk. 37; bu tarihlendirme Filiz Çağman ve Hilal Kazan tarafından ayrı çalışmalarda tarafından yapılmıştır, bkz. Filiz Çağman, Osmanlı Sarayı Tasvir Sanatı (İstanbul: Masa, 2016), 75; Hilal Kazan, "Farklı Açıdan Bir Bakıșla Șehnameci Seyyid Lokman'ın Saray için Hazırladı̆̆ı Eserler," Osmanlı Araştırmaları 35 (2010): 127. Bu belge için ayrıca, Emine Fetvacı, "The Office of the Ottoman Court Historian," Studies on Istanbul and Beyond: The Freely Papers. Volume 1, der. Robert G. Ousterhout (Philadelphia: University of Pennsylvania Press, 2007), 7-21. Eserin Süleymaniye Kütüphanesi'nde bulunan resimsiz ve daha kısa nüshası (Süleymaniye Kütüphanesi, Hekimoğlu 642) Ramazan 992 (Eylül-Ekim 1584) tarihlidir. Mehmet Arslan Süleymaniye yazmasının en erken tarihli nüsha olabileceğini öne sürüyor, bkz. Arslan, Intizâmi Surnâmesi, 34. Süleymaniye yazmasında konuları "cem iyyet"lere göre numaralandıran, yazmanın sonuna doğru düzensizleşip 231. cem‘iyyet’te sonlanan (14ob), kırmızı mürekkeple yazılmış derkenar notları vardır. Metni cem'iyyetlere ayıran bu notların yukarıda söz edilen talepten sonra, resimli yazmanın tasarlanmasına ve 250 meclis içeren bir kitap fikrini metne uygulamaya yönelik bir hazırlık olduğunu düşünüyorum. Resimli sûrnâme yazmasının durumu, eksik varaklar ve kitaba ait fihrist üzerine gözlemler ileride not edilmektedir.

31582 suru ve Sûrnâme için üzerine monografi niteliğinde çalışmalar için bkz. Robert E. Stout, "The Sûr-i Hümâyun of Murad III: A Study of Ottoman Pageantry and Entertainment," (doktora tezi, Ohio State University, 1966); eserin Avusturya Devlet Kütüphanesi'nde bulunan nüshasının transliterasyonlu yayını ve şenliğin bu yazma ışı̆̆ında bir değerlendirmesi için: Gisela Procházka-Eisl, Das Sürnāme-i Humāyūn. Der Wiener Handschrift in Transkription, mit Kommentar und Indices versehen (İstanbul: lsis Verlag, 1995); Mehmet Arslan'ın kapsamlı çalışması TSMK (H 1344) ve Süleymaniye Kütüphanesi (Hekimoğlu 642) yazmalarının transkripsiyonu ile birlikte, şenlik, sûrnâmeleri, ve İntizami üzerine değerlendirmeler içerir: Arslan, Intizâmi Sûrnâmesi. Sûrnâme metninden önce resimleri ile araştırma ve tahlil konusu olmuştur: Sezer Tansuğ un Şenlikname Düzeni (İstanbul: Everest, 2018 [1961]), Topkapı Sarayı Müzesi Kütüphanesi kopyası resimlerinin derinlikli bir yapısal ve görsel tahlilini içerir. Ayrıca bkz. Nurhan Atasoy, 1582 Surname-i Hümayun Düğün Kitabı (İstanbul: Koçbank, 1997); Uşun Tükel, "Atmeydanında Bir Senliğin Gösterimi: Klasik Dönem Osmanlı Minyatürünün Resim Dili," Hippodrom/ Atmeydant: İstanbul'un Tarih Sahnesi (İstanbul: Pera Müzesi, 2010), 96-110. Bu çalışma Sûrnâme resimlerinin görsel dilini bu dönem Osmanlı resminin betimleme kalıpları çerçevesinde ele alır. 1582 şenliğinin kültürel ve siyasi bağlamında bir değerlendirmesi için bkz. Derin Terzioğlu, "The Imperial Circumcision Festival of 1582: An Interpretation," Muqarnas 12 (1995): 84-10o. Şenlik ve kitabının Osmanlı șenlik kültürü ve gösterim sanatları bağlamında değerlendirmesi için bkz. Metin And, Osmanlı Senliklerinde Türk Sanatları (Ankara: Kültür ve Turizm Bakanlığı, 1982); Kırk Gün Kırk Gece: Osmanlı Düğünleri, Senlikleri, Geçit Alayları (İstanbul: Toprakbank, 200o [1959]) ve Özdemir Nutku, "Atmeydanı'nda Düzenlenen Şenlikler," Hippodrom/Atmeydanı, 71-95. İntizami sûrnâmesinin esnaf ve diğer meslek ehlinin alayları açısından bir incelemesi için, Gisela Procházka-Eisl, "Guild Parades in Ottoman Literature: The Sûrnâme of 1582," Crafts and Craftsmen of the Middle East: Fashioning the Individual in the Muslim Mediterranean, der. Suraiya Faroqhi ve Randi Deguilhem, (Londra: I.B. Tauris, 2005), 41-54. Senlikler üzerine bir literatür değerlendirmesi için, Suraiya Faroqhi, "Research on Ottoman Festivities and Performances," Celebration, Entertainment and Theater in the Ottoman World, der. Suraiya Faroqhi ve Arzu Öztürkmen (Londra: Seagull, 2014), 24-68. I. Süleyman (1520-1566) dönemi şenliklerine dair iki ayrı değerlendirme için Zeynep Yelçe, "Evaluating Three Imperial Festivals: 1524, 1530, 1539," Celebration, Entertainment and Theater in the Ottoman World, der. Suraiya Faroqhi ve Arzu Öztürkmen (Londra: Newyork, Seagull, 2014), 71-109; Kaya Sahin, "Staging an Empire: An Ottoman Circumcision Ceremony as Cultural Performance," The American Historical Review 123 (2018): 463-492. 1720 şenliği ve sûrnâmelerinin kapsamlı analizi için, Sinem Erdoğan İşkorkutan, "The 1720 Imperial Festival in Istanbul: Festivity and Representation in the Early Eighteenth Century Ottoman Empire," (doktora tezi, Boğaziçi Üniversitesi, 2017). 
rastlıyor. Bunu şehrî bakış açılarının resmedilebilir olduğu an olarak ayırt edebiliriz. Bu yazıda yapmaya çalışacağım, şehri sokak perspektifinden ve sokak düzleminde resmeden imgeleri ortaya çıkartan siyasi ve kültürel konjonktürün izini sürmek, bu temsillerin yerleştirildikleri kitaplar içinde ne tür okumalara aracilık ettiklerini sorgulamak ve bu sorgulamanın bir parçası olarak, mekânı ve temsillerini farklı aktörlerin öznellikleri aracılığı ile okumak, görsel düzeni ve temsili mekân pratikleri ile bir arada ele almak. ${ }^{4}$

Bu araştırmanın daha geniş çerçevesinde, kamusal mekân üzerinde aktörlerin değişen taleplerini, kamusal mekânların hayali, fiili ve performatif inşasını, mekân temsillerinin bu tür inşa süreçlerindeki rolünü, erken modern dönem (yeniçağ) İstanbul'unda hangi mecralarda, nasıl takip edebileceğimize dair bir dizi soru var. Yine İstanbul bağlamında erken modern döneme özgü yeni kamusallıkların görsel ve mekânsal boyutları, yeni oluşan toplumsal ilişki şekillerinin ve ağlarının, yeni-veya görünürlüğü artan-ifade şekillerinin ve dolaşım ağlarının bu dönemin mekânsal ve temsili pratikleri ile bağlantıları, görsel ve mekânsal alanlardaki izleri de, bu yazının daha geniş çerçevesinde bulunan sorular arasında. ${ }^{5}$ Bu sorular şöyle bir öneriden yola çıkıyor: On altıncı yüzyılın sonlarında Osmanlı tarih yazmalarına yerleşen sokak ve meydan temalı resimler bu sırada İstanbul'da dönüşmekte olan mekânsal pratiklerin ve görsel rejimin ürünleridir; bu dönüşümü şehir mekânlarının kurgusunda, kullanımında ve temsilinde takip etmek mümkündür. Bir yandan mimari müdahaleler bir yandan da Osmanlı elitlerinin ve İstanbulluların kentsel mekânlardaki fiilî, bedensel ve performatif varlıkları, şehrin kamusal mekânlarını ve bunların temsillerini dönüştürmüş; şehre dair metin ve resimler, saray çıkışlı anlatı ve imgelerin imkânlarını ve sınırlarını değiştirmişti.

150o'lerin sonları İstanbul'unun toplumsal ve siyasi dinamizmi ve bu dinamizme odaklanan tarihyazımı, değişen mekân pratiklerinin ve değişen görselliğin görünürlük kazandırdığı şehir ve şehirlilik tahayyüllerinin tarihselci bir yorumu üzerinde çalışmak için bir zemin sunuyor: Bu senelerin-büyük ölçüde göçlere bağlı olduğu düşünülen-hızlı nüfus artışı, kamusal hayata katılımın genişlemesi ve şehir hayatına katılım mecralarının çoğalması, yeni toplumsallıkların ve yeni türden aidiyetlerin oluşması ve ifade edilir olması, özellikle, şehirli zümrelerin ve şehirli aidiyetin görünürlük kazanmas1; ${ }^{6}$ bununla paralel bir süreçte, yine on altıncı yüzyıl sonlarından itibaren Osmanlı siyasasının ve kurumlarının yapısal dönüşümüne eşlik eden toplumsal-siyasi dinamikler, yani yeni ve hızla değişebilen siyasi mutabakatlar, sıklaşan, yoğunlaşan ve şiddetlenen toplumsal muhalefet ifadeleri, ayaklanmalar ve çatışmalar, bu dinamizmin veçheleri arasında sayılmalı.

Yazının başında sözünü ettiğim sûrnâme imgelerine ve benzerlerine ağırlıklı olarak saray perspektifinden bakmaya alışı̆ıı. Şehnâme esinli bir hükümdarlık imgesinin ve ikonografisinin on altıncı yüzyıl sonlarında yerini şehir ve saray odaklı temsillere bırakması üzerine yazan tarihçiler, edebi ve görsel tarih anlatılarındaki yeniliği Osmanlı siyasasının yerleşikleşme eğilimlerinin bir uzantısı olarak yorumladılar; yerleşikleşmenin ve yeni temsili gündemlerin ikonografik tercihleri de değiştirdiğini öne sürdüler. ${ }^{8}$ Yerleşikleşme dinamiklerinin, sarayın ve

4 Michel de Certeau'nun tartıştığı şekli ile mekân pratikleri kavramı ve yine de Certeau'nun otoriter ve hegemonik mekân tahayyülleri ile sokaktakilerin hareketli, kısmi, değişken mekân algısı üzerine gözlemleri, bu çerçeveye esin veren okumalar arasındadır. Bkz. Michel de Certeau, The Practice of Everyday Life, çev. Steven Rendall (Berkeley: University of California Press, 1984), özellikle 91-131.

5 Erken modern dönem Avrupa'sında kamusallık dinamiklerini Habermas ve Arendt çıkışlı kavramsal çerçeveler içerisinde, fakat deneyimlerin çoğulluğunu ve değişkenliğini önceleyerek irdeleyen, burada takip ettiğim sorular için bazı açılardan açıklayıcı bulduğum bir dizi çalışmayı zikretmem gerekir: Bronwen Wilson ve Paul Yachnin, der., Making Publics in Early Modern Europe: People, Things, Forms of Knowledge (New York: Routledge, 2011); Angela Vanhaelen ve Joseph P. Ward, der., Making Space Public in Early Modern Europe: Performance, Geography, Privacy (New York: Londra, Routledge, 2013); Paul Yachnin ve Marlene Eberhart, der., Forms of Association: Making Publics in Early Modern Europe, (Amherst: University of Massachusetts Press, 2015). Ayrica bkz. Bruno Latour, "From Realpolitik to Dingpolitik or How to Make Things Public," Making Things Public: Atmospheres of Democracy, der. Bruno Latour ve Peter Wibel (Cambridge, MA: MIT, 2005), 14-43.

6 Cemal Kafadar, "Janissaries and Other Riffraff of Ottoman Istanbul: Rebels without a Cause?," Identity and Identity Formation in the Ottoman World, der. Karl K. Barbir ve Baki Tezcan (Madison: Center for Turkish Studies, 2008), 113-134; "How Dark is the History of the Night, How Black the Story of Coffee, How Bitter the Tale of Love: The Changing Measure of Leisure and Pleasure in Early Modern Istanbul," Medieval and Early Modern Performance in the Eastern Mediterranean, der. A. Öztürkmen ve E. Birge Vitz (Turnhout: Brepols, 2016), 243-269.

7 Osmanlı siyasasının yapısal dönüșümü üzerine, Kafadar, "The Question of Ottoman Decline," Harvard Middle Eastern and Islamic Review 1-2 (1997-8): 30-75; Baki Tezcan, The Second Ottoman Empire: Political and Social Transformation in the Early Modern World (New York: Cambridge University Press, 2010).

8 Osmanlı siyasasındaki yerleşikleşme dinamiklerinin tarihyazımında ve resimli hanedan tarihlerindeki yansımaları için, Christine Woodhead, "Murad $\mathrm{III}$ and the Historians: Representations of Ottoman Imperial Authority in Late 16th-century Historiography," Legitimizing the Order: The Ottoman Rhetoric of State Power, der. Hakan T. Karateke ve Maurus Reinkowski (Leiden ve Boston: Brill, 2005), 85-98; Hakan Karateke, “'On the Tranquility and Repose of the Sultan': The Construction of a Topos,” The Ottoman World, der. Christine 
seçkinlerin başkent ile değişen ilişkilerinin, hanedan için yazılan ve resimlenen tarihlerdeki izlerini teslim ediyorum. Aynı zamanda, bu imgelere, resmedilen şehirlileri ve kentsel mekânı önceleyen bir dizi başka soru aracılığı ile de yaklaşmanın mümkün olabileceğini düşünüyorum. Birdenbire sokağa ve şehirlilere yer açmaya başlayan görsel temsillerin daha kapsayıcı bir yorumuna ulaşabilir, bunların sarayın temsili gündemlerinin ötesinde çoğul ve diyalojik okumalarına girişebilir miyiz? Bu türden okumaları tarihsel olarak temellendirebilir miyiz? Bu sorular saray kaynaklı resimlerin tebaayı yalnızca saray perspektifinden betimlemenin-yani sarayın şehre açılan penceresi olmanın-ötesinde, şehirlilerin perspektiflerini de içerdikleri önerisine dayanıyor. Nicholas Mirzoeff'in tanımıla "bakma hakkı," bu resimlerde ve onlara bağlı anlatılarda şehirlilerin gözlerini izlemek için bir yol açabilir. ${ }^{9}$ Mirzoeff bakma hakkını iktidarın kurduğu görsel düzene, öznel siyasi varlıkların ve kolektiflerin cevabı olarak tanımlıyor; görülebilir ve telaffuz edilebilir olan arasındaki ilişkileri belirleme bağımsızlığına sahip bir öznelliğe işaret ediyor. Görselliğin barındırdığı otoritenin karşısına, bakma hakkının barındırdığı otonomiyi yerleştiriyor. On altıncı yüzyıl sonlarının şehir odaklı resimlerinde iktidarın belirlediği görsel düzenin izleri ile birlikte "bakma hakkı"nın temsilini de bulabilir miyiz?

$\mathrm{Bu}$ çerçevenin ve sorular kümesinin belki zayıf noktasını, veya paradoksunu, diğer yandan ilginç ve takip etmeye değer bulduğum tarafını da burada ortaya koymam gerekir: Saray hiyerarşisinin en üst katmanlarında bulunan kişilerin aracılı̆̆ ile üretilmiş, öncelikli okurları hükümdar olan, nihayetinde hassa hazinesinde muhafaza edilen eserlerde şehrî bakış açılarını, şehirlilerin seslerini ve perspektiflerini aramak afaki bir meşgale olabilir. Diğer yandan, saray ve şehir, saraylı ve şehirli arasında mutlak ve aşılmaz sınırlar bulunduğunu varsaymıyorsak, bunların çeşitli düzeylerde geçişkenlikleri olan toplumsal ve fiziksel alanlar olduğunu teslim ediyorsak (mesela, parçası olduğu dünyanın pek çok yönünden şikâyetçi Mustafa Âli'nin [ö. 160o] tam da bu yıllarda sarayı, gireni çıkanı belli olmayan bedestene benzettiğini, bir yandan da şehirde haneleri olan saraylıları çatık kaşlarla zikrettiğini hatırlarsak ${ }^{10}$ ), bu türden bir okumanın yollarını araştırabiliriz. ${ }^{11}$ Bu senelerin belgelerinde saray ve şehir arasındaki geçişkenliğin kitap ve resim üretimindeki yansımalarından izler bulmak mümkündür: Bazı kitap projelerinde çalışmak üzere saray sanatçılarının yanı sıra "etraftan" nakkaşlar istihdam edilmesi veya kitap resimleme süreçlerinde nakkaşların sahip olabildiği otonomi, bu kitaplarda farklı seslerin ve bakışların izini sürmek için bir başlangıç noktası oluşturur. ${ }^{12}$

\section{Semavi Bakış ve Şehrin Karmaşası}

Bu soruların izini sürmeye, aynı yıllara ait başka bir eserin yine oldukça tanıdık, ve belki yeterince sorgulamadığımız başka-türden-bir resmi, Hünernâme’nin birinci cildinde bulunan İstanbul haritası ile başlayayım (şek. 1). Dört cilt olarak tasarlanmış ama bitirilmemiş olan bu hanedan tarihi projesinin III. Murad'ın hükümdarlığı sırasında tamamlanmış iki cildinden ilki, Osman'dan (yak. 1302-1324) I. Selim'e (1512-1520) kadar hüküm süren Osmanlı padişahlarının, ikincisi ise Kanuni Süleyman’ın hükümdarlığını anlatan ve öven metinlerden

Woodhead (New York: Routledge, 2012), 116-129; Emine Fetvac1, Picturing History at the Ottoman Court (Bloomington: Indiana University Press, 2013), özellikle 267-282.

9 Nicholas Mirzoeff, The Right to Look: A Counterhistory of Visuality (Durham: Duke University Press, 2011). Mirzoeff görsel arşivin madunları yalnızca betimlemediği, aynı zamanda seslerine aracılık ettiği önerisinin görsel kültür çalışmaları için önemli yöntemsel açılımları olduğuna dikkat çekiyor. Görsellik (tarihi ve kültürel bağlamı içerisinde görsel düzen olarak tanımlıyor bunu) otoritenin ifade edildiği ve yaygınlaştırıldığı bir mecra olmanın yanı sıra otoritenin neşesi olanlar için de bir ifade mecrasıdır. Fiziki anlamda görsel algının ötesinde, fiziki algı ile bilgi, tahayyül ve sezgilerin birleşimidir. Mirzoeff'e göre görsellik bütünü (complex of visuality) siyasitoplumsal düzenin barındırdığı sınıflandırma ve ayrıştırmaların estetize edilmesi ile oluşur. Karşı-görsellik (counter-visuality) görsel alanın dışında da ifade bulur. Mirzoeff'in izini sürdüğü, Anglo-Fransız emperyal projesinin parçası olan ve on yedinci yüzyıl ortaları ve sonrasında özellikle köle kolonilerinin kurulması ve idame ettirilmesi bağlamında oluştuğunu önerdiği görsel düzendir.

10 Gelibolulu Mustafa Âli, Künhüll-Ahbâr. Dördüncü Rükn: Osmanlı Tarihi (Ankara: Türk Tarih Kurumu, 2009), 567a-567b. Mustafa Âli için bkz. Cornell Fleischer, Tarihçi Mustafa Âli: Bir Osmanlı Aydın ve Bürokratı, çev. Ayla Ortaç (İstanbul: Tarih Vakf1 Yurt Yayınları, 1996). 11 Saray kitaplarında başka sesler (ve bakışlar) peşinde isek, Carlo Ginzburg'un ve Ginzburg'un esini Mikhail Bakhtin'in kurdukları kavramsal çerçeveleri zikretmek gerekir: Carlo Ginzburg, Myths, Emblems, and Clues, çev. J. Tedeschi ve A. Tedeschi (Londra: Hutchinson Radius, 1986); Mikhail Bakhtin, The Dialogic Imagination. Four Essays, çev. Caryl Emerson ve Michael Holquist (Austin: University of Texas Press, 1981).

12 Zübdetü't-Tevârih'in resimli yazmasının hazırlanmasında çalışmak üzere "etraftan" bulunup saray nakkaşhanesinde istihdam edilen, bazıları proje tamamlandığında sürekli olarak ehl-i hıref içine alınan sanatçlar için bkz. Fetvacı, "The Office," 11; Ferrûh ve Hûmâ yazmasının resimlenme sürecinde, sanatçların metni okuyarak resimleri tasarlamasına yönelik direktifler için bkz. Fetvacı, Picturing History, 77-78. 


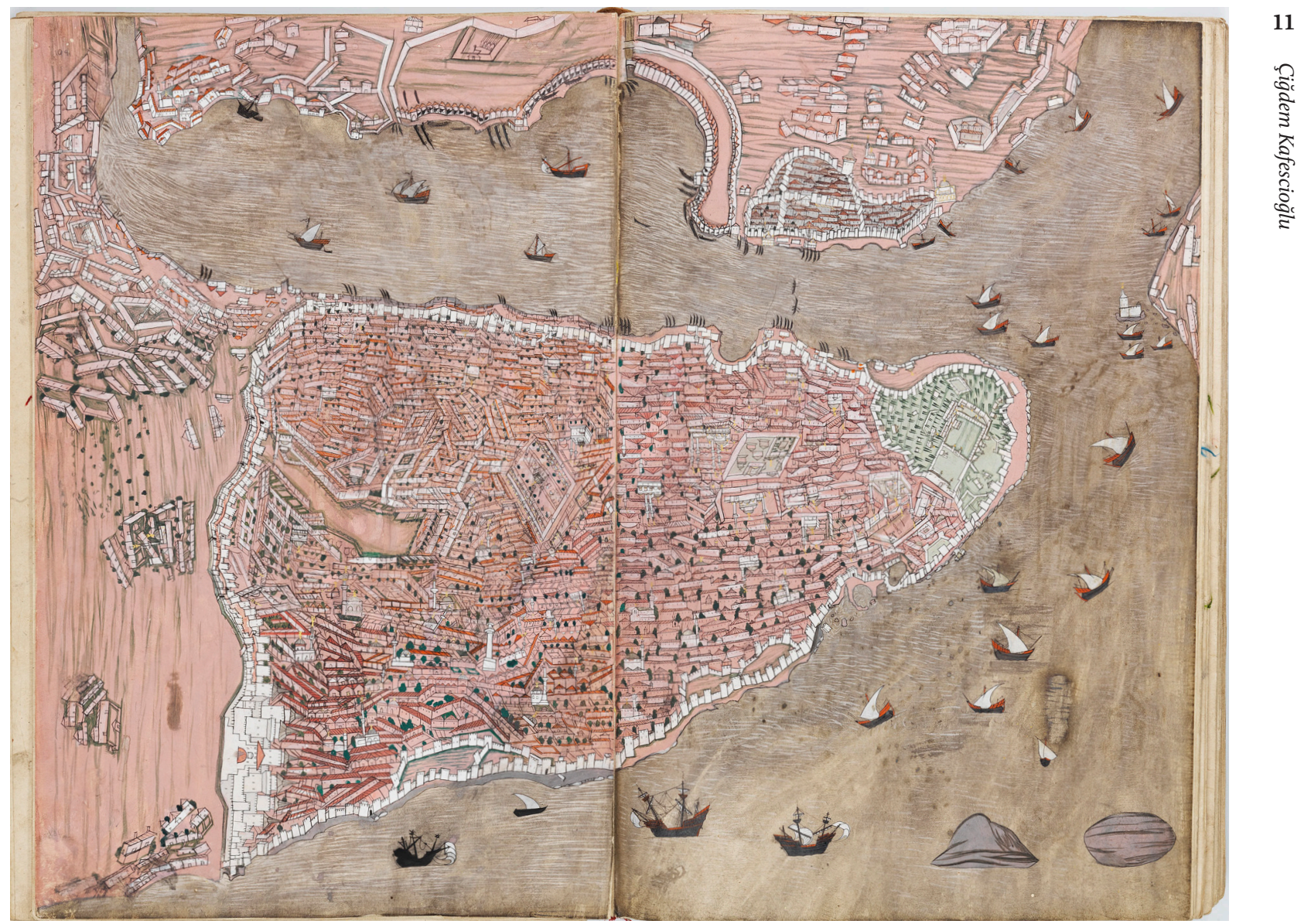

Şekil 1: İstanbul haritası. Seyyid

Lokman,

Hünernâme, c. 1, 1584-1585, TSMK H 1523, 158b-159a. oluşur. ${ }^{13}$ Hünernâme'nin Il. Mehmed'in saltanatına (1444-1446, 1451-1481) saltanatına ayrılmış kısmındaki harita, bu yıllarda şehnâmeci Seyyid Lokman'ca yazılmış üç ayrı hanedan tarihine eklenen ve birbiri ile bağlantılı görünen üç İstanbul haritasından biridir. ${ }^{14}$ On altıncı yüzyıl boyunca üretilmiş resimli Osmanlı tarihlerinin belirgin özelliklerinden biri, tarihi anlatıların mekânsal ve coğrafi boyutlarını vurgulayan yer tasvirlerini öncelemeleri ve özellikle harita türünden imgeleri tarihi anlatıların içsel parçaları olarak sunmalarıdır. Hünernâme'nin İstanbul haritası, bu pratiğin geç örneklerinden biridir. ${ }^{15}$ Diğer yandan pek de abartmadan diyebilirim ki Hünernâme'deki harita, İstanbul'un modern öncesi dönemde yapılmış herhalde en tuhaf görsel imgesidir. Şehrin hemen tanınabilir coğrafi sınırları, coğrafi ve mimari sınırlar dâhilindeki, Osmanlılar nezdinde önemli tüm anıtları bu büyükçe haritada görülebilir. Fakat bunlar son derecede yoğun ve karmaşık, Escher-vari, imkânsız mekânsal oyunlar içeren, binbir perspektifin üst üste bindirilerek birbirlerine kilitlendiği bir sokak dokusunun içerisindedirler (şek. 2).

13 Seyyid Lokman, Hünernâme, c. 1, TSMK H 1523. Hünernâme yazmalanının resim programlanı için bkz. Serpil Bağc1 et al. Osmanlı Resim Sanatı (Ankara: Kültür Bakanlığı, 2007), 140-152; Serpil Bağcı, "Visualizing Power: Portraits of the Sultans in Illustrated Histories of the Ottoman Dynasty," Islamic Art 6 (2009): 113-127; Fetvac1, Picturing History, 149-189.

14 Hünernâménin İstanbul haritasının burada üzerinde durduğum açılardan daha detaylı bir incelemesi ve ilgili referanslar șu makalede bulunabilir: Çiğdem Kafescioğlu, "Viewing, Walking, Mapping Istanbul, ca. 1580," Mitteilungen des Kunsthistorischen Institutes in Florenz, LVI (2014): 16-35. Bu harita için ayrıca bakınız: Iffet Orbay, "Istanbul Viewed: The Representation of the City in Ottoman Maps of the Sixteenth and Seventeenth Centuries," (doktora tezi, Massachusetts Institute of Technology, 2001), 73-116. Aynı senelerde üretilmiş ve birbirleri ile bağlantılı, daha geniş bir haritalandırma projesine ișaret ettiklerini düşündüğüm üç harita: Seyyid Lokman, Hünernâme, c. 1, 158b-159a; Seyyid Lokman, Șehinșehnâme, c. 1, İstanbul Üniversitesi Kütüphanesi, F 1404, 58a; Seyyid Lokman, Zafernâme, Dublin Chester Beatty Library T 413, 22b-23a.

15 Harita tarzı şehir temsillerinin resimli Osmanlı tarihlerindeki seyri için, Bağcı et al., Osmanlı Resim Sanatı, 69-81; Çiğdem Kafescioğlu, "Görsel Sanatlar," Türkiye Tarihi 1453-1603, der. Suraiya Faroqhi ve Kate Fleet, çev. Egemen Özkan (İstanbul: Kitap Yayınevi, 2016), 603-607. Dönemin haritacılık pratiklerini imparatorluk kültürü açısından irdeleyen bir çalışma için bkz. Pınar Emiralioğlu, Geographic Knowledge and Imperial Culture in the Early Modern Ottoman Empire (Burlington: Ashgate, 2014). 


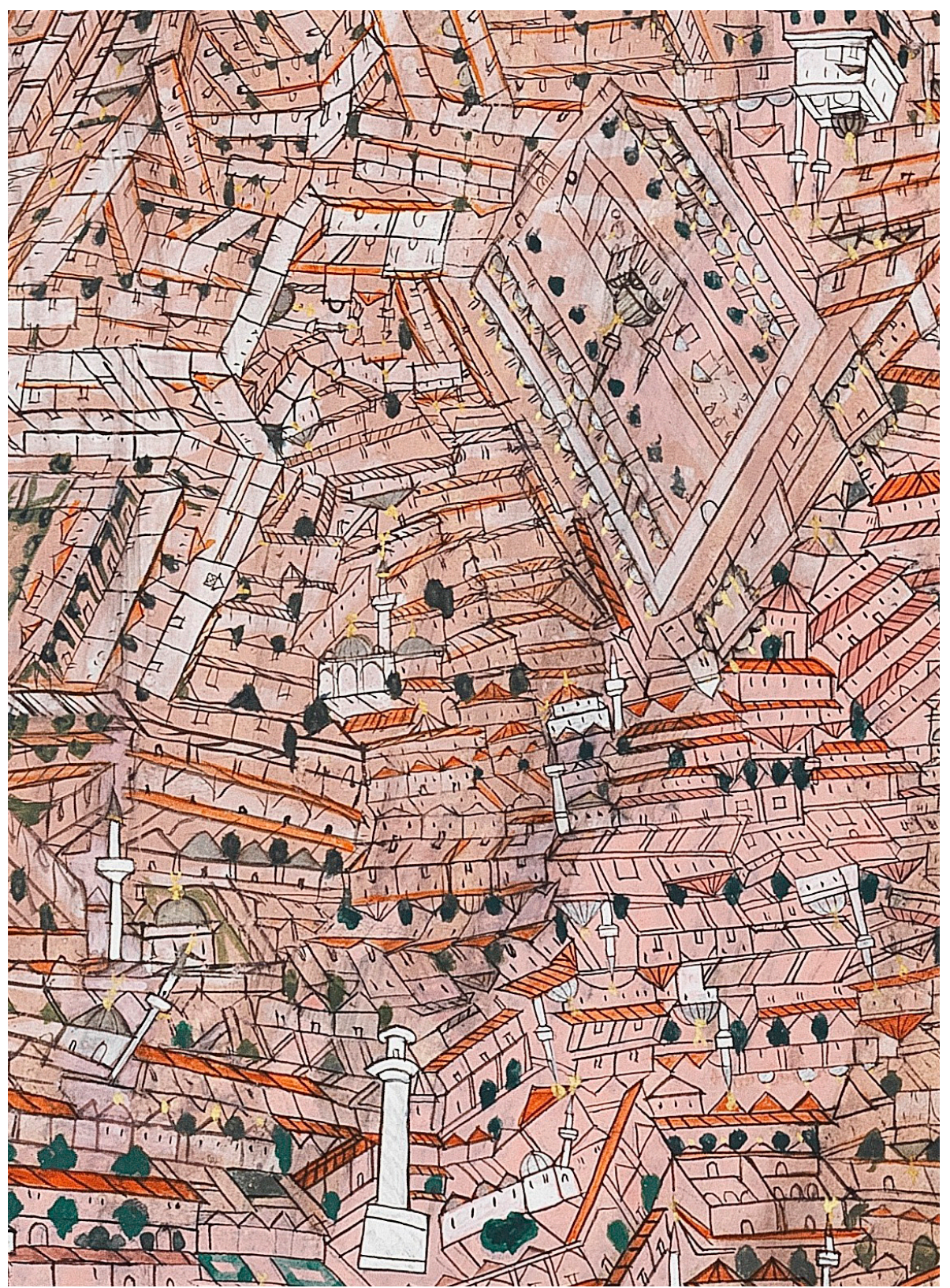

Osmanlı şehir haritalarının ve manzaralarının daha erken veya çağdaş birkaçına hızlıca bir bakış, Hünernâme haritasının farklılığının altını kalınca çizer. Matrakçı Nasuh’un (ö. 1564) 1530'lar ve 1540'larda kitaplaştırılmış tarih ve menzilnâmelerini resimleyen şehir görüntüleri, veya Hünernâme'den bir on sene kadar sonra yine tarih odaklı bir siyasi risalede, şehnâmeci Talikizade'nin (ö. 16oo) Şemailnâme'sinde bulunan Manisa manzarası, yine çok perspektifli, fakat düzenli bir geometrinin hâkim olduğu, geometrik yapının mekânsal bir hiyerarşiyi ve bununla örtüşen ideal bir siyasi/toplumsal düzeni ifade ettiği bir görsel şema üzerine kurulmuştur. ${ }^{16}$ Hünernâme haritasında şehir dokusunun yoğunluğuna dikkat çeken araştırmacılar, bu tasvirin on altıncı yüzyıl sonlarında başkentteki kayda değer nüfus artışını yansıttığını önermişlerdir, fakat nüfus yoğunluğu bu imgenin barındırdığı görsel karmaşayı anlamak için pek tatmin edici bir cevap oluşturmaz. Aynı
Şekil 2: İstanbul haritası, detay. Seyyid Lokman, Hünernâme, c. 1, 1584-1585, TSMK H 1523, 159a. 


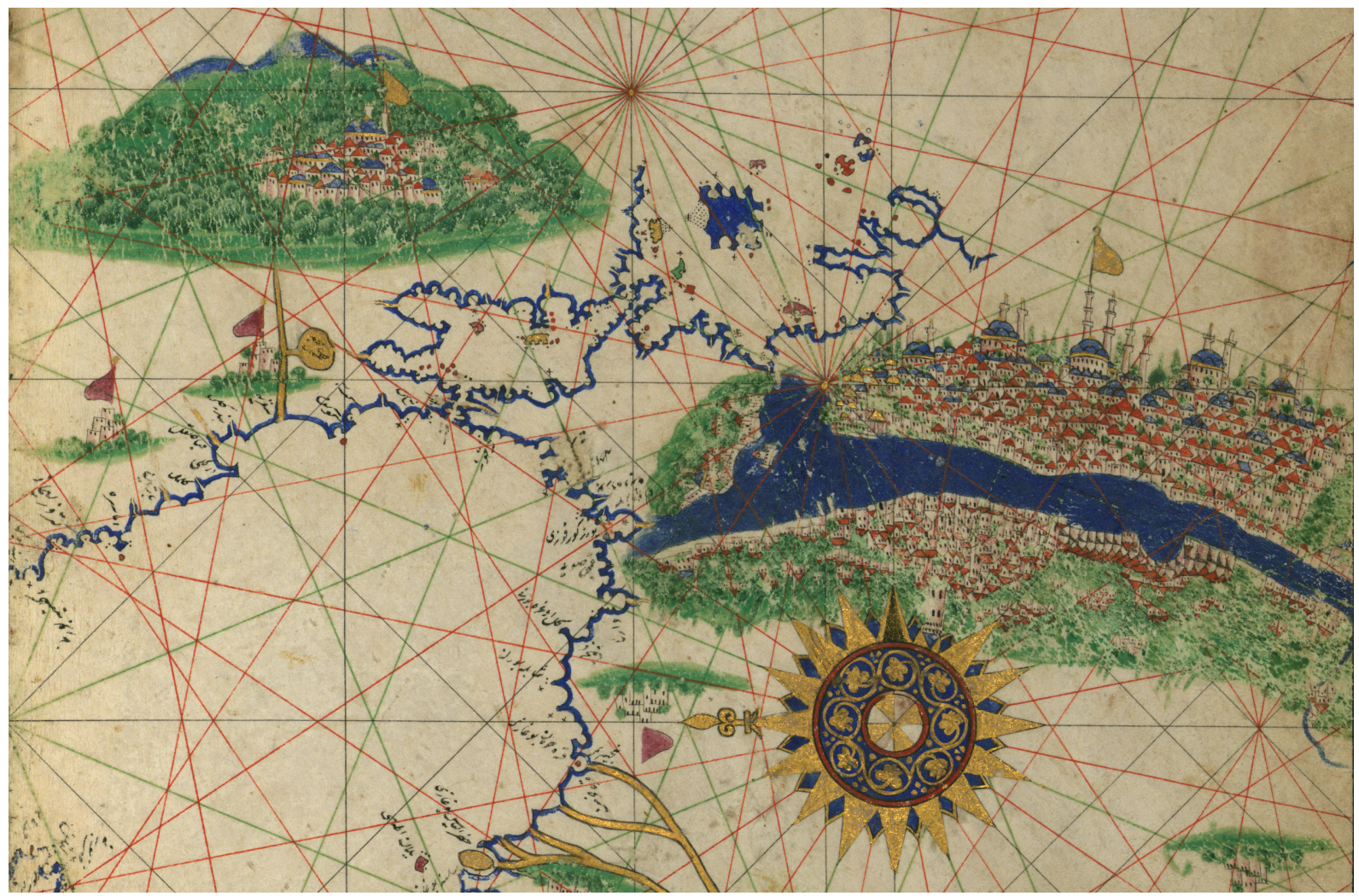

Şekil 3: Karadeniz ve Marmara denizi haritasında İstanbul ve Bursa manzaraları. Atlas, on altınc1 yüzyıl ikinci yarısı, Walters Art Museum, W 660, 9 a. dönemde, deniz haritacılığı çerçevesinde üretilen İstanbul manzaraları, yine çok yoğun, ama Suriçi'ni Galata üzerine yerleşmiş tek bir bakış açısından tasvir eden, aynı anıtların bu defa benzer yapıların sürekli tekrarı ile oluşan homojen bir yerleşim dokusu içinde göründüğü imgelerdir (şek. 3).

Şehirleri gökyüzünden, ilahi veya siyasi bir erkin bakışını çağrıştıran bir yerden ve açıdan resmeden haritalar ve 'kuşbakışı' manzaralar bu dönemin Avrupa ve Osmanlı mekân temsillerinin ortak bir özelliğidir. İmparatorlukların ve toprak hâkimiyetine dayalı devletlerin güçlerini pekiştirdikleri dönemde ortaya çıkan, mekân tasavvurları açısından akrabalıkları olan bu haritalar Akdeniz, Avrupa ve Osmanlı coğrafyalarında farklı şekiller alır: İçlerinde yer aldıkları kitaplar ve bağlantılı oldukları metinlerle ilişkileri, yazma veya baskı olmaları, dâhil oldukları üretim ve dolaşım ağları, görsel dillerini olduğu kadar kullanımlarındaki farklılıkları da belirler. ${ }^{17}$ Birbirlerinden farklı temsil kalıpları ile şekillenmelerine ve farklı görsel etkiler yaratmalarına karşın Avrupa ve Osmanlı dünyalarında aynı dönemlerde yaygınlaşan harita ve manzaraların ortaklıkları da çarpıcıdır: Semavi bakış, şehri tanımlanabilir-ve anlamlandırılabilir - bir bütün olarak resmetmenin aracıdır. Birbirlerinden farklı tarz ve tekniklerle, her iki tür "harita” da, birden çok bakış açısını içerir. Osmanlı ressamlarınca yapılmış şehir manzaralarının bir özelliği, binaların plan, cephe ve aksonometrik görünüşlerini birbiri üzerine bindirerek çoklu bakış açılarını örtüştürme yöntemini (İrani dünya ile ortaçağda ve erken modern dönemde İslami dünyanın resim geleneklerinde yaygın bir temsil tarzıdır) kentsel mekânın tümünün temsiline uyarlamalarıdır. Bu imgeler ayırt edilebilir

17 Avrupa şehir manzara ve haritalarını on beşinci yüzyıl sonlarından itibaren baskı üretim ile ilişkileri içerisinde de irdeleyen çalışmalar için Jürgen Schulz, "Jacopo de’Barbari's View of Venice: Map Making, City Views, and Moralized Geography before the Year 1500," The Art Bulletin 6o (1978): 425-474; Lucia Nuti, "The Perspective Plan in the Sixteenth Century: The Invention of a Representational Language," The Art Bulletin 76 (1994): 105-128; Hilary Ballon ve David Friedman, "Portraying the City in Early Modern Europe: Measurement, Representation, and Planning," History of Cartography III, 1: Cartography in the European Renaissance, der. David Woodward (Chicago: University of Chicago Press, 2007), 680-704; Sean Roberts, Printing a Mediterranean World: Florence, Constantinople, and the Renaissance of Geography (Cambridge: Harvard, 2013). 'Kuşbakışı' şehir manzarası terimini tırnak içinde, sehirleri farklı temsil kalıplarına göre resmeden, fakat kentin mekânsal bütünlüğünü resmetme iddiası açısından ortaklıkları olan imgelere işaret etmek üzere kullaniyorum. 


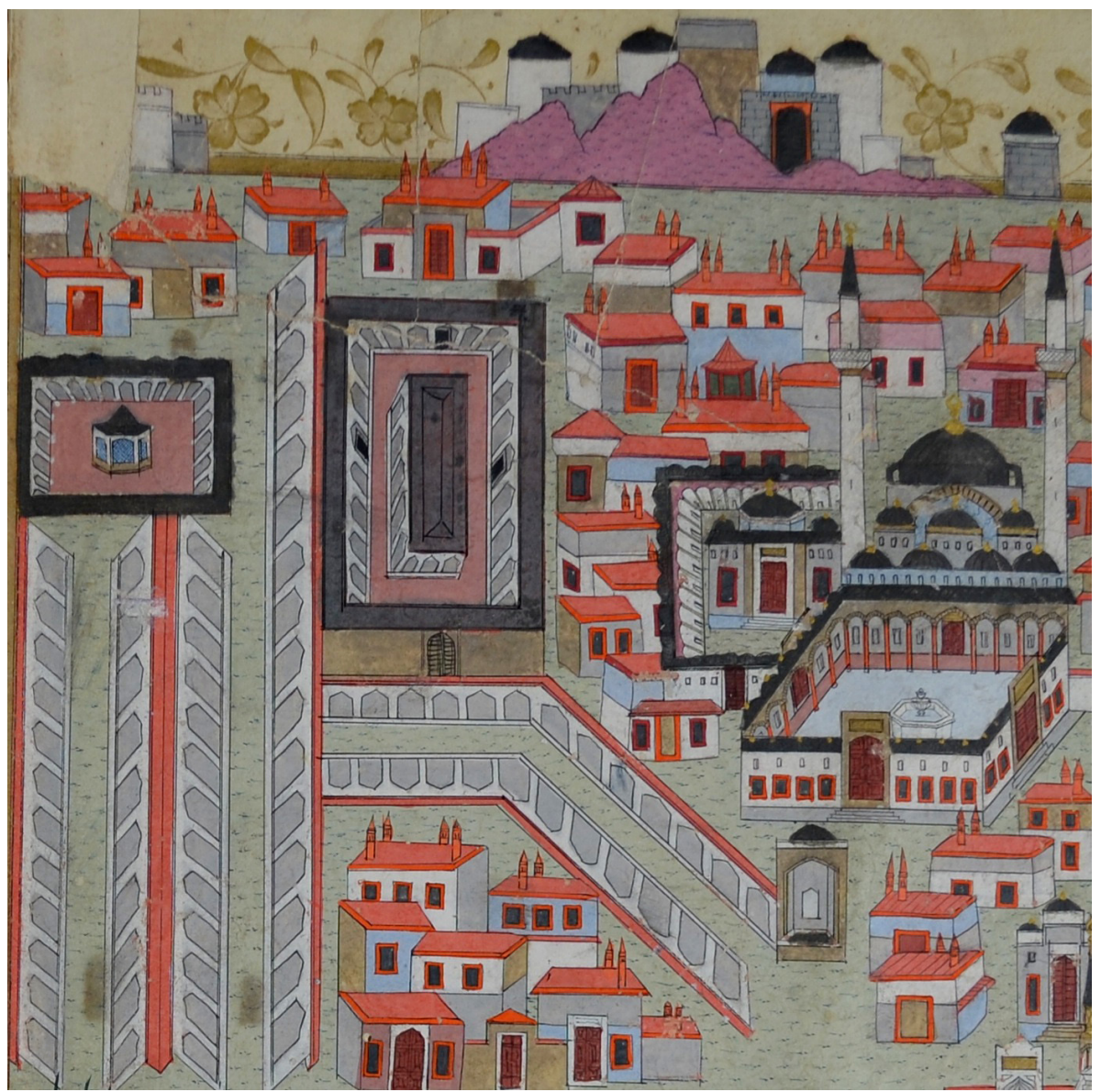

Şekil 4: Manisa manzarası, detay. Talikizade, Şemâilnâme-i Al-i Osman, 1590 civarı, TSMK A 3592, 1ob-11a.

yapılardan oluşan bir kentsel doku tasvir eder (şek. 4). ${ }^{18}$ On beşinci yüzyıldan itibaren Avrupa'da yaygınlaşan, Osmanlı ülkesinde de dolaşıma giren ve özellikle deniz haritacılığı alanında üretilen 'kuşbakışı' manzaralar, başka türden bir perspektif oyununa girişirler. Kentsel dokuyu farklı bakış açılarından resmetmekle ve resim düzlemini de eğip bükmekle birlikte, temsil edilenin gerçekliği önerisine sıkı sıkıya bağlı kalırlar: Resmedilen, şehrin üzerinde, gökyüzünde bir noktaya yerleşmiş olduğu varsayılan bir gözün gördükleridir. Her iki temsil kalıbında da perspektif oyunları bütünlüklü ve kapsayıcı şehir imgesini oluşturmanın araçlarıdır. Özellikle baskı şehir manzaralarının kurallarına aşina olduğu anlaşılan, hem Osmanlı hem de Avrupa haritacılığına atıfta bulunan Hünernâme haritacısı her iki tarzdan da görünür şekilde ayrılan bir temsil yöntemi izler: ${ }^{19}$ Baskı haritaların perspektif bütünlügü önerisinden de, İrani ve Rumi resim geleneğinin çok perspektifli fakat geometrik düzeni ve hiyerarşiyi önceleyen temsil yönteminden de uzak durur.

Hünernâme haritasını 'tuhaf' yapan bu ortak temsil tercihlerinden ayrılışı, semavi bakışı birçok sokak perspektifinin karmaşası ile bir araya getirişidir. Haritacı-ressam, her iki pratiğin özelliklerini serbestçe kullanır, Suriçi’nde, şehrin ortalarındaki mahalleleri resmederken iki pratiğin kurallarına da sırtını döner. Osmanlı ve Batı dünyalarında, gerek elyazması

18 Bu tarz, Osmanlı resimli yazmalarında özellikle Matrakcı Nasuh'un menzilnâme formatındaki iki eserinde, Beyân-ı Menâzil ve Târîh-i Feth-i Şikloş, Estergon ve İstulnibelgrad'da ortaya çıkar, 159o'lara tarihlenen Manisa haritasında görüldügü gibi yüzyıl boyunca tarihyazımı çerçevesinde kullanımda kalır; farklı mecralarda on dokuzuncu yüzyıl sonlarına kadar görünür olacaktır; bkz. Nasuhü’s-Silahi, Beyān-ı Menāzil (dipnot 16) ve Süleymannâme. Târîh-i Feth-i Şikloş, Estergon ve İstulnibelgrad, haz. Tevfik Temelkuran (İstanbul: Tarihi Araştırmalar Vakfı, 1998). Bu tür şehir temsillerinin tahlilleri için bkz. Uşun Tükel, "Beyan-ı Menazil'in Resim Dili: Bir Yapısal Çözümleme” (doktora tezi, İstanbul Üniversitesi, 1990); "Beyan-1 Menazil'in Resim Dili Üzerine bir Anlamlandırma Denemesi," Türk Kültüründe Sanat ve Mimari: Klasik Dönem Sanatı ve Mimarlığı Üzerine Denemeler, der. Mehmet Saçlıoğlu ve Gülsün Tanyeli (İstanbul: 21. Yüzyıl Eğitim ve Kültür Vakfı, 1993), 190-206; Orbay, "Istanbul Viewed," 29-72; Çiğdem Kafescioğlu, Constantinopolis/Istanbul. Cultural Encounter, Imperial Vision, and the Construction of the Ottoman Capital (University Park: Pennsylvania State University, 2009), 207-213; ayrica bkz. dipnot 14.

19 Hünernâme haritasının Avrupa'da bu dönemde baskı ortamında üretilen șehir haritalarıyla bağlantıları için; Kafescioğlu, "Viewing, Walking, Mapping," 27-31. 
gerekse de matbu olarak üretilmiş şehir haritalarının bütüncüllük ve gerçekçilik önerileri bilinen, kabul edilmiş temsili imkânsızlıklar üzerine kurulmuştur. Hünernâme haritacısı farklı bakış açılarını çarpıştırarak başka bir dil geliştirir. Mimari kütlelerin iki/üç boyutlu temsillerini örtüştürür; bir grup binanın cephe çizimleri başka binaların çatı kütlelerine dönüşür, cephelere ve çatılara ait unsurlar sokak ve avluların çeperlerini tanımlar. $\mathrm{Bu}$, en karmaşık ve en fantastik mekân temsillerinde bile tekil mimari unsurların bütünlüğünü koruyan Timurlu ve Safavi dönemlerinin İran resim geleneğinden (Züleyha’nın yedi odalı sarayında Yusuf'un Züleyha'dan kaçışını tasvir eden ünlü Behzad resmini düşünelim ${ }^{20}$ ) veya bu temsil kalıbını şehir temsiline uyarlayan, mesela Matrakçı eserlerinde bulunan temsil dilinden uzaklaşan bir tavırdır. Hünernâme haritası 1580'lerde Osmanlı başkentini ideal şehir olarak resmetmenin imkânsızlığını gösterir gibidir. Şehre gökyüzünden, semavi bir açıdan bakan göz, ona hükmedenlerin bakışını temsil ediyorsa, binaların ve sokakların düzensizce birbiri üzerine bindiği, kesişen, çarpışan ve iç içe geçen cephe ve plan görüntüleri öznel sokak deneyimlerinin çoğulluğuna ve değişkenliğine işaret eder. Tümüyle insansız bu imge bedenin sokaktaki varlığını anıştıırken, bir yandan da okuyucudan bedensel bir katılım talep eder: Açık durumda 50 x $64 \mathrm{~cm}$ ebatlarındaki bu büyük resmin temsili bütünlüğü ile ufak ve karmaşık detaylarını bir arada algılayabilmek için okur, aynı anda hem geniş açıı hem makro lensleri kullanabilir olmalıdır. Üstelik, resmedilen dokunun karmaşı detaylarını görebilmesi ancak kitabın büyük cüssesinin üzerine eğilmesi, bu koca cildi evirip çevirmesi veya etrafında dolaşması ile mümkündür.

Mustafa Âli'nin divanında bulunan bir İstanbul kasidesi, özellikle de ilk beyti, şehri seyreden gözlerin ve onu oluşturan bakışların çoğulluğunun yaygın ve başka mecralarda da ifade bulan bir izlek olabileceğini düşündürür:

Dirin İstanbul'a ben ehl-i nazar deryâsı

Kesret-i nâsa nazar nev'-i beşer deryâsı

İstanbul'u "ehl-i nazar deryâsı" olarak tanımlayan, nüfusunun kalabalığını barındırdığı insan tiplerinin çokluğu ile ilişkilendiren ve bu çeşitliliğin ancak nazar sahipleri, yani görme duyuları ve zihinsel melekeleri aracılığı ile görme/anlama yetisi bulunan kişiler tarafından okunabileceğini sezdiren bu beyit, Hünernâme haritasının da yalnızca yerleşimin niceliksel yoğunluğunu değil, bu yoğunluğun işaret ettiğgi çeşitliliği ve canlılı̆̆ da temsil ettiğini, belli bir tür görme tarzını ve yetisini gerektirdiğini düşündürür. Geniş ve karmaşık semantik yelpazesi içerisinde bakma, mülahaza etme, düşünme, gözlem, kuram, sezgi anlamlarını barındıran nazar sözcüğü, İslami kültürde ortaçağlardan itibaren gelişen, görmeyi fiziki ve duyusal boyutlarının yanı sıra içsel (zihinsel, kalbi ve ruhani) boyutları da olan bir edim olarak kavramsallaştıran fikirler kümesine karşllık gelir. Diğer yandan ehl-i nazar'ın topluma ve topluluk içindeki kişilere yönelik bakışını, erken modern dönemin kültürel dinamikleri bağlamında da düşünmek anlamlı olacaktır. İslam'ın ilk dönemlerinde mu'tezile grupları için kullanılan ahl al-nazar terimi sonraları daha geniş anlamda âlim ve düşünürleri, herhangi bir konuda gözlem yaparak akılcı bir yöntemle fikir ifade edebilen kişileri tanımlamak üzere kullanılmıştı. Mustafa Âli’nin kullanımı ehl-i nazar'ın gözlemlerini bilgiye, sezgiye ve anlayışa dayandırma ve toplumu bu şekilde tanıma ve ayrıştırma yetisine sahip kişilere işaret ettiğini düşündürüyor. Mevâidü’n Nefâis’inde feraset, yani insanları görünüş ve kıyafetlerine göre tanıma ve ayrıştırma ilminin şehir ortamındaki gerekliliği üzerinde defaten durmasını ve bu ilmi im‘ân-ı nazar ile, yani zihin aracılığı ile derinlikli olarak görme ve anlama yetisi ile bağdaştırmasını da bu bağlamda, bu dönemin toplumsal dinamizmini göz önüne alarak değerlendirmek mümkün. ${ }^{21}$

20 Sadi, Bustân, Kahire Milli Kütüphanesi, Adab Farsi 908, 52b; Oleg Grabar, Mostly Miniatures: An Introduction to Persian Painting (Princeton, Princeton University Press, 200o), 64; resim için bkz. "Yusef Zuleykha," Wikipedia, erişim tarihi 3 Ağustos 2019, https://www.wikizeroo. org/index.php?q=aHRocHM6Ly9lbi53aWtpcGVkaWEub3JnL3dpa2kvRmlsZTpZdXNlZlyadWxleWtoYS5qcGc.

21 "Ehlünnazar," İslam Ansiklopedisi, c. 4 (İstanbul: Milli Ĕ̈itim Basımevi, 1950), 208; "Ahl al-nazar," Encyclopedia of Islam, Second Edition, erişim tarihi 25 Kasım 2019, http://dx.doi.org/10.1163/1573-3912_islam_SIM_0384. Yüzyll başlarında yazan Nev'izâde Atayi de, Sohbetü’' Ebkâr'inda ehl-i nazar terimini yer yer bu anlamda kullanıyor, bkz. Nev'izâde Atayi, Sohbetüll Ebkâr, haz. Muhammed Yelten (ìstanbul: i.Ü. Edebiyat Fakültesi, 1998); Mustafa Âli, Mevâidü’n Nefâis fî-Kavấidi'l-Mecâlis, haz. Mehmet Şeker (Ankara: Türk Tarih Kurumu, 1997), 381-382. Feraset için, Emin Lelic, "Ottoman Physiognomy ('Ilm-i Firâset): A Window into the Soul of an Empire" (doktora tezi, Chicago Üniversitesi, 2017). Gülru Necipoğlu mimarinin algılanıș1 ve değerlendirmesi üzerine söylemlerde "nazar sahibi (erbâb-ı nazar, sâhib nazar) olma" yetisinin üzerinde durulmasına dikkat çeker: Necipoğlu, Sinan Çağı: Osmanlı İmparatorluğunda Mimarî Kültür (İstanbul: Bilgi Üniversitesi, 2013), 293, 342, 407. Ayrica bkz. dipnot 47, 49 ve 50. 
Mustafa Âli’nin deryâ redifli kasidesinin devamı, ehl-i nazarın gözleri önündeki şehrin resmidir. Âli şehri çevreleyen deniz imgesini (denizin bolluğunu, güzelliğini, kıpırtısını, ışığını, dinmez hareketliliğini, tekinsizliğini) başkent/metropolün tüm özellikleri ile örtüştürür:

Ümm-i dünyâ vü şeker bahrı ise Nil ile Mısr

Ebi yâ ceddidür anun bu matar deryâsı

Günde bin şahsı kesüp kanını bahr itmek olur

Hışm-1 şeh demleri husrân u hatar deryası

Emr-i Hak ile veba demleri geldükde hemân

Lücce-i zehr olur ol hûn-1 ciger deryâsı

Azl ile fakr ile göz yaşı döken gamgîne

Gussa gird-âbıdur ol hüzn ü keder deryâsı

Mâ’il-i fısk u fücûr olsa harâbât ehli

'Alemi gark-1 şarâb eyler o şer deryâsı

Mansıb ehline safâ kanı menâfi‘ denizi

Merdüm-i düşkine şer‘ bahrı zarar deryâsı

Anma zühhâd ile pür-savma'alar hem-çü sadef

Görinür dâne-i sübhayla dürer deryâsı

'Ulemâsı fuzelâsı şu'arâsı çokdur

'Ukalâ bahrıdur ol fazl u hüner deryâsı

Atlanup cum‘aya çıkdukça şehenşâh-1 cihân

Zib ü fer menba'ıdur nûr-1 basar deryâsı

Akdeniz Karadeniz'den çekilüp geldükçe

Bahr-1 limânı görinür gemiler deryâsı

Görinür her yolı bâzârınun âdem oluğı

Cûş ü cünbişde eger şehr eger deryâsı

Didi sarrâf-ı hıred ana ki bezzâzistân

Ma‘den-i dürr ü güher nukre vü zer deryâsı

Bir içim su gibi dil-berler ile toptoludur

'Alemin yüzi suyudur o püser deryâsı

Döndi bir deyre ser-â-pâ ola pür-nakş u nigâr

Zenlerün kânıdur ol süfte güher deryâsı

Leb-i deryâdadır amma tutuşup yandukça

Her zebâne dil olur kendi şerer deryâsı

Bahr u berden çekilüp gitmede ebnâ-yı sebîl

Ümerâ reh-güzeri nakl u sefer deryâsı

Gerçi seyyah-1 ekâlim-i cihandur 'Alî

Öyle ber-ter bir döner görmedi ber deryâsi ${ }^{22}$

Bu şehir bir yağmur deryasıdır; "hışm-1 şeh günleri”"nde hüsran, korku ve ölüm, veba günlerinde zehir ve kan deryasıdır; azledilenler, fakirlik içinde gözyaşı dökenler için hüzün ve keder deryası, fısk u fucur, alemi şaraba gark eden şer deryasıdır; makam sahipleri için sefa ve menfaat, düşkünler için zarar ve kötülük deryasıdır. Dervişlerin, ulema ve fuzelanın şehridir; fazilet ve hüner, sultan cumaya çıktığında ışık deryasıdır. Şehri çevreleyen, limanları gemilerle dolu deniz gibi, sokakları insan nehrini andıran çarşı da coşku ve hareket içerisindedir: cûşü 
cünbişde eger şehr eger deryâsı. Altın ve gümüş, inci ve mücevher deryasıdır; bir içim su dilberler, güzel oğlanlar, baştan ayağa süslü hafifmeşrep kadınlar, şehri tutuşturup yangınlara gark eden kıvılcımlar deryasıdır. Ve nihayet bu şehir bir seyyahlar deryası, seyahatin ve hareketliliğin merkezidir. Mustafa Âli de Hünernâme haritasının kimliğini bilmediğimiz ressamı gibi şehrin üzerine başka başka mercekler tutarak erken modern dönem metropolünün şaşaasını ve sefaletini, huzursuz karmaşasını resmeder. İkisi de, İstanbul'u payitahtın bütünlüklü temsillerine hakim olan ütopik, şehri ve şehir aracılığı ile onu yöneten siyasi erki idealize eden kavramsal çerçevenin dışından tasvir ederler; tezatları ve karmaşayı, güç ve zenginlik işaretleri ile bir araya getirirler. Semavi gözle birlikte, yere, sokağa yerleşik gözlerin varlı̆̆ını kuvvetle hissettirirler.

\section{Meydanın Resmi: Osmanlı Tarihlerinde Atmeydanı Anlatıları}

Hünernâme haritası bu senelerde şehnâmeci Lokman tarafından yazılan hanedan tarihlerine eklenen son üç İstanbul haritasından biridir ve bu kitabın barındırdığı, harita türündeki tek resimdir. Kitabın hemen sonraki resmi okuru gökyüzündeki biraz eğreti tahtından yeryüzüne indirir ve şehrin meydanına getirir: Fatih Mehmed Atmeydanı'nda yılanlı sütuna şeşper atmakta, "Ayasofya patriği" onun şehri yılanların istilasından koruyan bu kadim tılsıma zarar vermesini önlemeye çalışmaktadır (şek. 5). Şehnâmeci Lokman’a göre II. Mehmed İstanbul'u fethetmesinin hemen ardından "tahmid ve tebcil ve tekbir ve tehlil ile" Atmeydanı'na varmış, "bakır ejderi gördüklerinde tahammül idemeyüp" şeşper-i hümayunu ile hedef almıştır.23 Hâlbuki Târîh-i Ebül-Feth'ini 1490 civarında tamamlayan Tursun Bey bu konudaki uzun ve etraflı anlatısında II. Mehmed'i İstanbul'a girmesinin ardından doğruca Ayasofya'ya, şehrin başat dini ve siyasi anıtını ziyarete götürür; bu konuda yazan diğer Osmanlı tarihçileri de sultanın Ayasofya ziyaretini ve burada kılınan ilk Cuma namazını anlatırlar, meydandan bahsetmezler. ${ }^{24}$ Metinde ve resimde okurun karşısına çıkan yeni anlatının kaynakları nedir?

Hünernâme’nin Kanuni Süleyman'ın hükümdarlığına ayrılan ikinci cildinden bir bölüm bu soruya başka bir açıdan yaklaşmamıza vesile olabilir: Bu, şehirden bir günlük mesafede avlanırken Sultan Süleyman'ın karşısına çıkıp, bir miras davasının adil çözümünü isteyen yaşlı bir kadının ("bir acûze-i dâd-hâh") hikâyesidir. ${ }^{25}$ Bu epeyce dolambaçlı anlatıda yaşlı kadının ölmüş olan erkek kardeşinin dul karısı, dul kadının miras payını artırmak için ölenden doğduğunu iddia ettiği (fakat aslında satın almış olduğu) bir erkek bebek ve bebeklerini para karşılığında ona veren fakir çift boy gösterir. Kısacası, hükümdarın karşısına çıkıp ondan adalet talep eden kadın Sultan Süleyman'ın kendisine bahşettiği tüm lütufları reddederek şikâyetine devam eder, talebi konunun dava-yı şeri i ile çözülmesidir. Metne göre yaşlı kadın ve diğerleri İstanbul'a gelir, Atmeydanı'nda halk ile "akışu akışu temâşaya bakışugiderler," nihayet Beylerbeyi Kapısı'na ulaşıp huzûr-ı şeriye çıkarlar. Yan sayfadaki resimde hikâyenin çoğu kadın karakterini mahkemede değil Atmeydanı’nda görürüz, yaşlı kadın bir yeniçeri çavuşu ile karşı karşıyadır, bir kağnı kucağında bebek ile fakir kadını (veya dulu) sahneye sokar; yılanlı sütunun dibine oturmuş bir başka kadın ona yaklaşan bir çavuşla konuşur. Bazıları okuyucuya arkası dönük erkekler meydanı seyreder; alt köşedeki seyircilerin yüzü meydana, biri ise okura dönüktür (şek. 6). Bu hikâyeyi ve resmi Timurlu ve Türkmen resimli yazmalarının yerleşmiş bir anlatısının ve ikonografik kalıbının, yani Sultan Sencer'in yaşlı bir kadınla karşılaşmasının hikâyesi ve resimlerinin, yeniçağa özgü uyarlaması olarak anlayabiliriz. Nizami'nin Mahzenü'lEsrâr'ında anlattı̆̆ı șekliyle nasihatnâme tarzındaki Sultan Sencer hikâyesinin merkezinde yaşlı kadının hükümdardan adalet talebi vardır; bu hikâyeyi betimleyen İrani ve Rumi ressamlar kadının sultanla karşılaşmasına odaklanırlar. ${ }^{26}$ Hünernâme'deki resimde ise Sultan Süleyman görülmez, yerini kadıya ve beylerbeyine bırakmıştır; resim, adaletin icra edileceği mekânın, hikâyede belirtildiği üzere mahkeme değil, şehrin ana meydanı, Atmeydanı olduğunu düşündürür. Kadı ve beylerbeyinin resimdeki konumları hükümdara yer vermeyen

\footnotetext{
23 Seyyid Lokman, Hünernâme, c. 1, 161b-162a.

24 Tursun Bey, Târîh-i Ebû'l-Feth, haz. Mertol Tulum (İstanbul: Baha Matbaas1, 1977), 62-65.

25 Seyyid Lokman, Hünernâme, c. 2, 249b-25ob.

26 Sultan Sencer ve yaşlı kadın resimleri ile Hünernâme’nin I. Mehmed ve I. Süleyman'a dair kısımlarında bulunan benzer hikâyeler ve hükümdar temsilleri için bkz. Filiz Çağman, "Sultan Sencer ve Yaşlı Kadın Minyatürlerinin İkonografisi," Sanat Tarihinde İkonografik Araștırmalar Semineri Güner Inal’a Armağan Kitabı (Ankara: Hacettepe Üniversitesi, 199o), 87-116; Bağcı, "Visualizing Power, 119-121. Bu temanın İran resminde örnekleri için Eleanor Sims et al., Peerless Images: Persian Painting and Its Sources, (New Haven: Yale University Press, 2002), 216-218.
} 


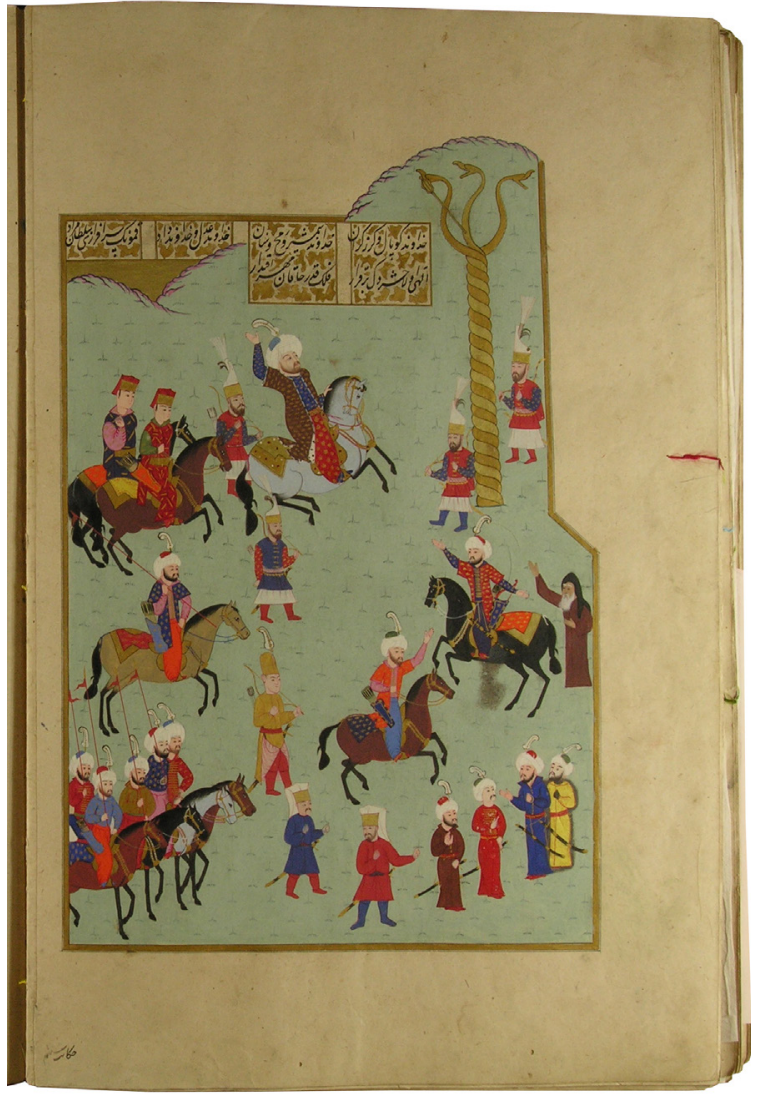

Şekil 5: Il. Mehmed Atmeydanı'nda yılanlı sütuna şeşber atarken. Hünernâme c. 1, 1584-1585, TSMK H 1523, 162b.

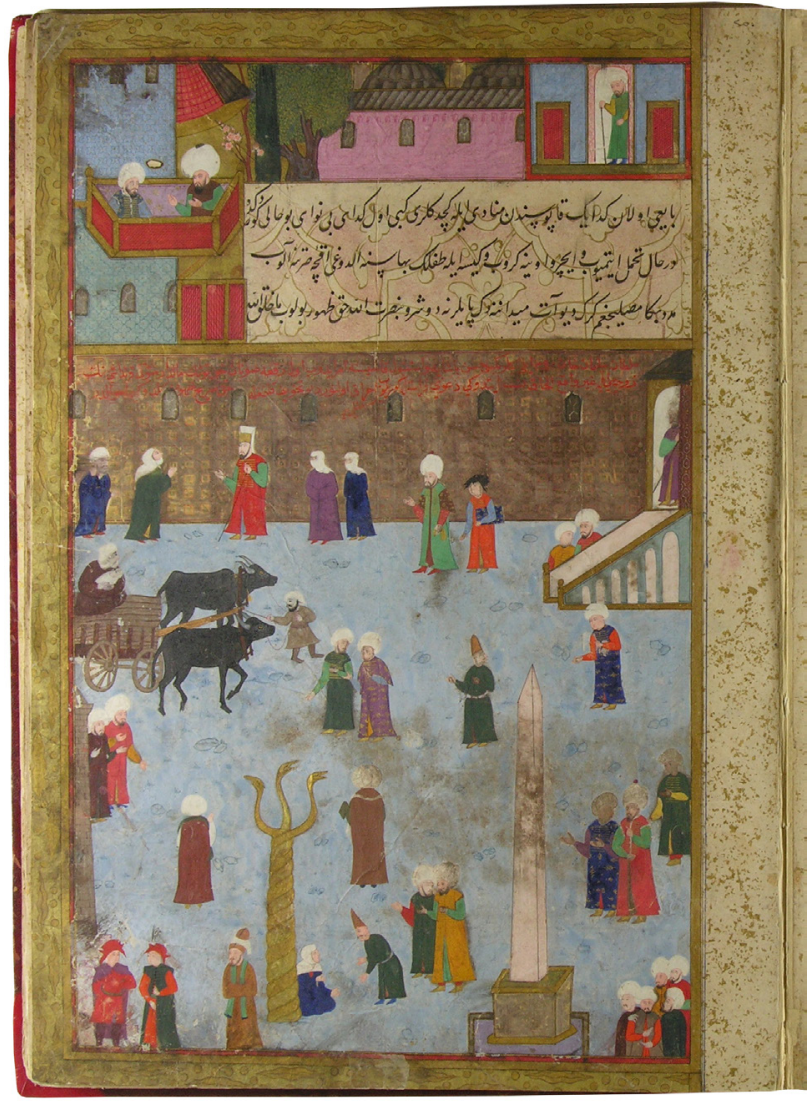

Şekil 6: Atmeydanı'nda kadınlar. Nakkaş Osman ve atölyesi, Hünernâme c. 2, 1588, TSMK H 1524, 25 ob.

bu "hükümdar ve yaşlı kadın" anlatısında iktidarı temsil ettiklerine işaret eder: İbrahim Paşa Sarayı'nın ön cephesindeki, biraz sonra üzerinde duracağım yazmada "nazargâh-1 şâh-1 cihânpenâh" olarak tanımlanan sultana ayrılmış çıkmada oturmakta ve meydanı seyretmektedirler.

Siyasi karşılaşma ve müzakere yeri, adaletin uygulandığı ve sergilendiği yer olarak Atmeydanı, Osmanlı metinlerinde on beşinci yüzyıl sonlarından başlayarak takip edebildiğimiz bir izlek. ${ }^{27}$ Atmeydanı'nın siyasetin ve adaletin yeri olarak en erken tarihli betimleri arasında Otman Baba Velayetnâmesi'ni hatırlayabiliriz: Bu cezbeli ve öfkeli abdalın İstanbul fatihi, saray erkânı ve ulema ile karşılaşmalarını çarpıcı imgelerle anlatan metne göre 1470'lerde şehirde epey karışıklık yarattığı anlaşılan Otman Baba, dervişleri ile Atmeydanı'na yerleşir, İstanbulluların hayretle dolu bakışları önünde kerametler sergiler. Velayetnâmeye göre daha sonra Atmeydanı'na getirilip, burada hazırlanan kazık ve çengeller yoluyla siyaset edilecekken

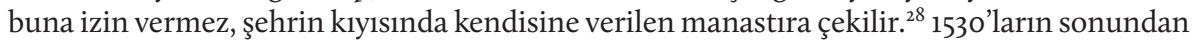

27 Hipodrom-Atmeydanı için bkz. Wolfgang Müller-Wiener, Istanbul'un Tarihsel Topografyast: 17. Yüzyll Başına kadar ByzantionKonstantinopolis-Istanbul, çev. Ü. Sayın (İstanbul: Yapı Kredi Yayınları, 2002 [1977]), 64-71; Ekrem lşın ve Brigitte Pitarakis, der., Hippodrom/ Atmeydanı: A Stage for Istanbul's History, 2 cilt (İstanbul: Pera Müzesi, 2010). Erken modern dönem İstanbul'unda kamusal ve siyasi bir alan olarak Atmeydanı ve Osmanlı şehir tarihi yazımının sorunlu bir noktası olarak Osmanlı ve İslam şehirlerinde meydanların bulunmadığı varsayımı, dikkat çekilmiş, ancak yeterince irdelenmemiş konulardır. Bkz. Sussan Babaie ve Çiğdem Kafescioğlu, "Istanbul, Isfahan, and Delhi: Imperial Designs and Urban Experiences in the Early Modern Era (1450-1650)," A Companion to Islamic Art and Architecture, der. Gülru Necipoğlu ve F. Barry Flood (Oxford: Blackwell, 2017), 2: 846-73, Kafescioğlu, Constantinopolis/Istanbul, 123-25, 135-139; Gülay Yılmaz, "Urban Protests, Rebellions and Revolts," Companion to Early Modern Istanbul, der. Shirine Hamadeh ve Çĭgdem Kafescioğlu (Leiden: Brill, 202o'de yayınlanacak); Damla Gürkan Anar, "Isfahan and Istanbul in the Early-Seventeenth Century: Masjid-e Shah and Sultan Ahmed Complexes" (doktora tezi, Boğaziçi Üniversitesi, yazım aşamasında).

28 Buradan yeniden şehrin merkezine, bu defa Topkapı Sarayı'na yöneldiğinde Il. Mehmed'e "sen bir şehirlüsün padişah benem" diyecek, "sehirlü”nün anlam katmanlarından biri için bir ipucu bırakacaktır. Bkz. Küçük Abdal, Otman Baba Velayetnamesi (Tenkitli Metin), haz. Filiz Kılıç, Mustafa Arslan, Tuncay Bülbül (Ankara: Grafiker, 2007), 249-51, 253; Otman Baba Velayetnamesi'nin Il. Mehmed dönemi bağlamında bir değerlendirmesi için Halil İnalcık, "Dervish and Sultan: An Analysis of the Otman Baba Velayetnamesi," The Middle East 
iki metin meydanın cesametini ve güzelliğini överken, burayı bir karşılaşmalar alanı, halkın ve seçkinlerin, şehrin güzel erkeklerinin bir araya gelme yeri olarak anlatacaklardır. Taşlıcalı Yahya'ya göre meydan "mecma'-ı hubân-ı şehsûvârân ve menba'-ı âşsık̂n-ı dilfigarân"dır; âdem denizi, hâs ile âmın toplanma yeridir; Safi'ye göre deniz genişliğinde, ayna temizliğinde ve parlaklığında, mermer sütunları göğe ulaşan, şehri sarsan bir kalabalığı barındıran, kendisininse bu kalabalıktan azade "tâlib-e rû-ye civânân" dolaştığı yerdir. ${ }^{29}$ Küçük Abdal ve İntizami'yi ayıran yüz yılı aşkın zaman zarfında pek çok yazar Atmeydanı'nı siyasetin ve adaletin, seyir ve temaşanın yeri, karşılaşmalar alanı olarak tasvir eder, ama bu temalar görsel alanda ancak 1580 'lerde ifade bulacaktır.

Kadınların Atmeydanı'nda adalet arayışının tasviri beni başlangıç noktama, III. Murad Sûrnâme'sine ve onun yazarına götürüyor, çünkü bu resmin görsel düzeni Sûrnâme'nin iki yüzden fazla resminde tekrarlanan kompozisyondan bir alıntı niteliğinde. Sûrnâme resimleri Osmanlı resim geleneği içinde fazlaca tanıdık olduğumuz ve sıklıkla karşılaştığımız imgeler arasındadır, ama bu resimlerin görsel düzenini Sûrnâme metni ve bu dönemin diğger kaynakları ile birlikte ve dönemin siyasi-sosyal dinamikleri çerçevesinde düşünmek bu yazıya şekil veren soruları takip etmeye yarayabilir. Atmeydanı'nın seyr ü temaşanın ve siyasetin yeri olarak resmi bu kitapta oluşur, şehir merkezinin imgesi bu kitap ve resimleri vasitası ile diğer Osmanlı resimli tarihlerinde yer bulur, tashih edilir, yeniden yorumlanır: 1580 ve 1590 'larda Atmeydanı'nın ve İbrahim Paşa Sarayı'nın resmedildiği, saray atölyelerinin ürünü pek çok imge Sûrnâme resimlerinden esin taşır. ${ }^{30}$

1588 senesi sonlarında tamamlanmış olan, orta ebatta $(23,8 \times 33,8 \mathrm{~cm})$ fakat hacimli, günümüze ulaşan hali ile 432 varaklık bu yazma, bugün barındırdığı, çoğu çift sayfaya yerleştirilmiş 224 resmiyle dönemin en yoğunlukla resimlendirilmiş kitabıdır. Günümüze ulaşmış dört Sûrnâme yazması, bu yazmaların birinin derkenarındaki otobiyografik anlatı ve resimli yazma için hazırlanmış olduğu anlaşılan bir fihrist, Sûrnâme'nin yazılışı ve resimli kopyanın üretim aşamaları üzerine fikir verir. Şehzade Mehmed'in sünnet şenlikleri sırasında Süleyman Efendi isimli bir kadı sûr hikâyesini kitaplaştırmasını, bu vesile ile arzu ettiği gibi divan kâtipliği ile ödüllendirileceğini söylemesi üzerine İntizami bir günün anlatısını Hasan Ağa isimli bir doğancı aracılı̆̆ılla saraya sunar. Anlatıya göre sultan bu taslağı beğenerek sûrun başlangıcından sonuna kadar yazılacağı bir kitap ısmarlar, marifet ehli olarak vasıflanan İntizami'ye divan kâtipliği verilir. ${ }^{31} \mathrm{Bu}$, elimizde biri 1584 tarihli iki kopyası (Süleymaniye ve Viyana nüshaları) bulunan kısa Sûrnâme olmalıdır. Üç sene sonra "döndü devr-i felek" diye yazar İntizami: Ansızın padişahtan gelen ve divana da ulaşan bir "ferman" (başka bir dizede divana ulaşan hatt-1 şerif olarak geçer) ve haremağası Mehmed Ağa’nın aracılığı ile, bu yazının başında anlatıldığı gibi sûrun her biri resimli 250 meclis içinde anlatılacağı, hazinede muhafaza edilecek yeni bir nüshasının yazılması istenir. Bu aşamada, Emine Fetvacı'nın dikkat çektiği, kitap üretiminde bu döneme özgü hamilik mekanizmaları devreye girer: İntizami Sûrnâme'yi yeniden yazar; yeni metnin sonunda, bu yeniden yazma sürecinde harem ağaları Mehmed ve Zeyrek'le "ekseri müşâvere olunduğunu," onların görüşlerine göre metinde yeni tashihler yaptığını anlatacaktır. Yazmanın üretimi sırasında çalışanların istihdamı konusunda Şehnameci Lokman'ın, resimler konusunda da nakkaşhanenin başında bulunan Nakkaş Osman'ın önemli rolleri olur. ${ }^{32}$

Resimli Sûrnâme’nin yapısını bu bilgilerle birlikte incelemek, yeniden yazım işinin şeklini ve kapsamını özellikle sûrun 250 meclis etrafında anlatılmasının belirlediğini ortaya koyar.

and the Balkans under the Ottoman Empire: Essays on Economy and Society (Bloomington: Indiana University Turkish Studies, 1993), 19-36; Balkan toplumsal ve siyasi dinamikleri bağlamında bir değerlendirme için, Nikolai Antov, The Ottoman "Wild West": the Balkan Frontier in the Fifteenth and Sixteenth centuries (New York: Cambridge University Press, 2017), 71-93. Bu velayetnâmede İstanbul ve mekân odakl anlatılar için, Kafescioğlu, Constantinopolis/Istanbul, 136, 140; "Dervishes in and out of the City," yazım aşamasında. Ayrıca bkz. Aslı Niyazioğlu, "Poets, Sufis, and Their City Tours (1450-1600)," A Companion to Early Modern Istanbul, der. Çiğdem Kafescioğlu ve Shirine Hamadeh (Leiden: Brill, 202o'de yayınlanacak).

29 "Cem'olurlar oraya hâs ile âm / san ki âdem denizidür ol makâm," Ralph Jaeckel, "Dukaginzade Taşlıcalı Yahya Bey's King and Beggar. A Sixteenth Century Ottoman Allegorical-Mystical Love Poem (Mesnevi)” (doktora tezi, UCLA, 1980), 178-79; Safi, Şehrengîz, Nuruosmaniye Kütüphanesi 3383, 33a-33b. Şâh u Gedâ 1538-1540 tarihli, Safi'nin Farsça şehrengizi 1537-1538 tarihlidir.

30 Nurhan Atasoy bu yazma ve resimlerden bazılarına dikkat çeker; Atasoy, 1582 Surname-i Humayun, 17. Resimli Sûrnâme'nin tamamlandığı noktada Hünernâme'nin ikinci cildinin resimlenmesinin devam ediyor olması, Hünername'de bulunan Atmeydanı resimlerinin Sûrnâme'den ilham taşyor olabileceği düsüncesini destekler. BOA, KK.d. 250, vrk. 27; bkz. dipnot 2.

31 Arslan, Intizâmi Sûrnâmesi, 41-43; Atatürk Kütüphanesi'nde (O.108) bulunan Sûrnâme yazması derkenarındaki otobiyografik anlatı. 32 Seyyid Lokman'ın resimli Sûrnâme'nin üretimindeki rolü için Fetvac1, "The Office," 10, Picturing History, 7o, 187; Çağman, Osmanl Sarayı, 75; Kazan, "Farklı Açıdan," 127-129; ayrıca bkz. dipnot 2. İtizami Sûrnâme’sinin "Vasf-1 nakkâs ve sıfât-1 u" başlıklı eksik son kısmı Üstad Osman'ı "zikr olunan mecâlisün nakkâşı ve ressâmı" olarak tanımlar ve nakkaşa bir övgü niteliğindedir, İntizami, Sûrnâme. 432b; Arslan, Intizâmi, 489-90. 

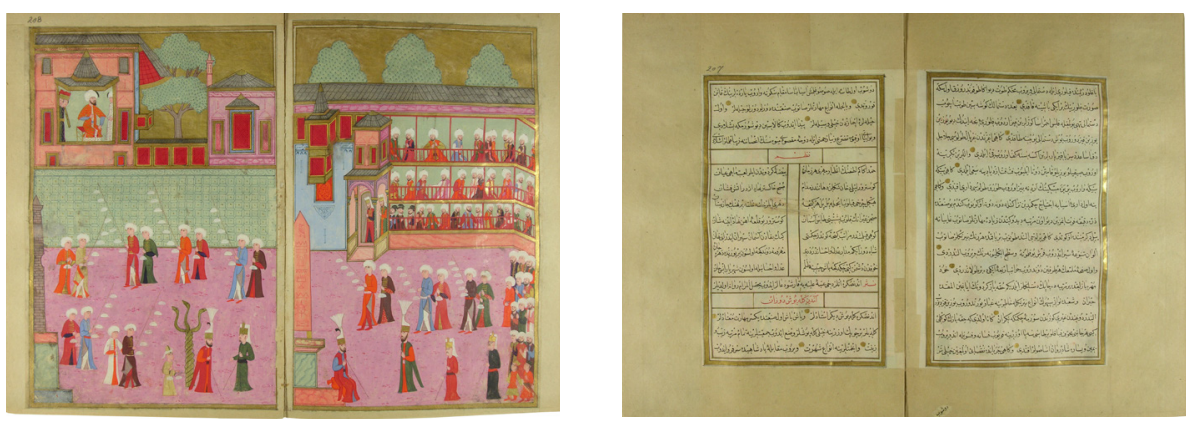

Şekil 7a-7f: İntizami, Sûrnâme, TSMK H 1344, 1588, 206b-212a. (Yazmanın metin ve resim düzeni, sağdan sola ve yukarıdan aşağıya: $207 \mathrm{~b}$ : ameden-i kellepûş-dûzân; 207b-208a: resim- kellepûşdûzân; 209a: ameden-i katırciyan; 209b-210a: resim- katırcıyan; 211a: ameden-i nalçacıyan; 211b-212a: resim-nalçacıyan
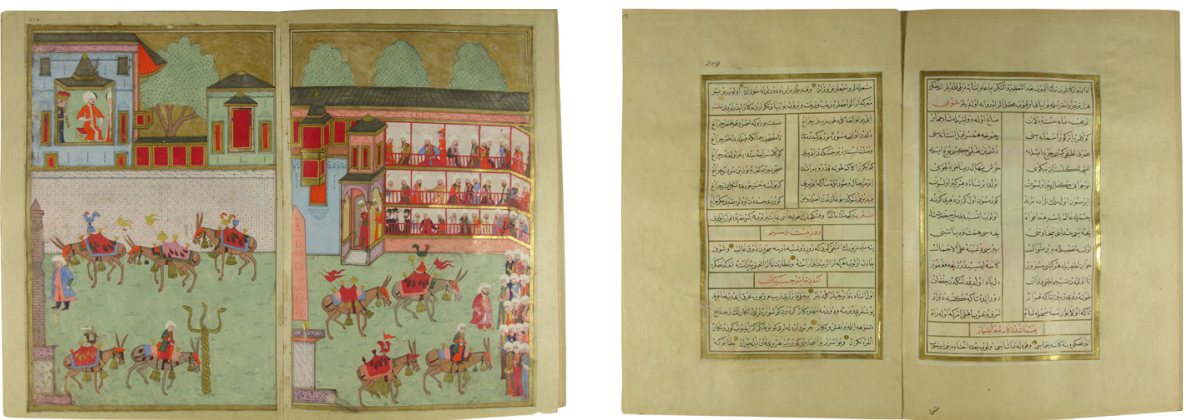
ve diğer esnaf.)
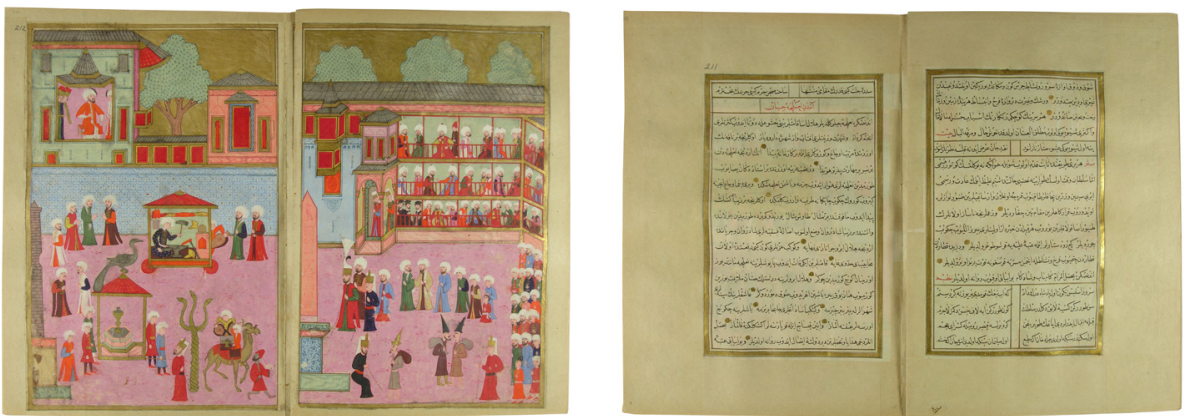

Kitabın—orijinal halini bilemediğimiz_baş ve son sayfaları dışında hemen tümünde metne ayrılmış her çift sayfayı, yine çift sayfaya yerleştirilmiş bir resim takip eder; her yazılı çift sayfada bir başlık altında konu edilen ehl-i hıref taifesi, gösterilere katılanlar veya şölen, yağma, meydanın temizliği gibi olaylar (eğer birden fazla konu başlığı varsa bunlardan biri) yazılı sayfaları takip eden çift sayfada resimlenir. Kaybolmuş, az sayıda da sırası değişmiş varaklar olmakla birlikte bu yapının orijinal yazmada şenlik anlatısının tümünü belirlediğini varsayabiliriz (şek. 7a-7f). Resimlenmek üzere yeniden yazılan metin bu tasarıma uyacak şekilde, yani seçilmiş metin başlıklarının hemen arkasında o konuda çift sayfa bir resim olacak, bu başlığa ait metin resmi takip eden varaklarda bitecek; sonra yeni başlık ve yeni resimle devam edecek şekilde yazılmıştır. Bu yapı, İntizami'nin yeni metni tamamen bu tasarıma göre oluşturduğunu ortaya koyar; ${ }^{33}$ herhalde yine aynı nedenle resimli kopyada diğerlerinden daha uzun anlatılar, İntizami'nin şiirlerine ve başka şairlerden alıntılara daha çok yer verilir. Yeniden yazım sırasında ilk nüshadaki, belki sûrun gerçekleşme düzenini daha yakından yansıtan anlatı yer yer bozulur: mesela Süleymaniye ve Viyana nüshalarında, Süleymaniye Camii maketinin meydandan geçirilmesi ile başlayan inşaat ehlinin çoğunun Atmeydanı'ndan geçme silsilesi (cami maketinin getirilmesini takiben camcılar, taşcılar, hakkaklar, ertesi gün sermimar-Sinan-eşliğinde Kâbe ve Medine maketlerinin geçişi, bir sonraki gün kireççi ve horasan ustalarının alayı) ${ }^{34}$ resimli kopyada terk edilir, bu cemaatlerin

33 Bu düzenin bozulduğu birkaç yer vardır: Bedesten tüccarlarının geçidi beş sayfaya yayılan uzun bir metinle (TSMK H 1344, 77b-81a, resim 79b-8oa), hamamcı esnafı yine uzun bir metin ve metin-resim sıralamasına sadık kalınarak ve bir hamam modeli ve peștemalmodellerle yapılan geçidi betimleyen iki resimle anlatılır (TSMK H 1344, 336a-339b, resimler 336b-337a ve 338b-339a).

34 Süleymaniye, 132b-135b, Arslan, 620-623; Viyana, Prochazka-Eisl, Das Sürnāme-i Humāyūn, 162-164. Benna ve tahtabürler bu dizgide yer 
geçitleri farklı günlerde anlatılır. Bu düzenlemenin de ardışık metin-resim düzenini korumak ve resim dizgisinde Sezer Tansuğ un gözlemlemiş olduğu görsel çeşitlilik kaygısının yanı sıra tematik çeşitlilik de yaratmak üzere yapılmış olması muhtemeldir.

Elimizdeki yazmalar ve Topkapı Sarayı Müzesi Arşivi’nde bulunan, “99o'da (...) kırk gün kırk gice devâm iden Şehzade Mehmed'in sünnet dügüni sûrnâmesin fihristi” başlıklı, otuz sekiz gün içerisine yerleştirilmiş 250 başlık sunan fihrist, tasarlanmasından sonlanmasına kadar kitabı şekillendiren fikre ışık tutar. Yukarıda not ettiğim gibi, İntizami metnin iki ayrı yerinde kitapta tümü resimli 250 meclis olduğunu belirtir. Bugün yazmada bulunan on dokuz tek sayfalık resmin yan sayfalarının ve çift sayfaya yerleştirilmiş yirmi altı resmin kayıp olduğunu varsayabiliriz. Bu sayılar, yetmiş birden fazla kayıp varak olduğunu, yazmadaki metin kayıplarının-ilk ve son sayfalar dışında-kaybolan resimli varakların arka yüzünde bulunan parçaları kapsadığını düşündürür.35 Resimli Sûrnâme’nin bölüm başlıkları ile büyük ölçüde örtüşen 250 başlık sunan Sûrnâme fihristi bize ulaşmayan varaklarda bulunan konular ve resimler konusunda fikir verir: Yazmanın başında harem ağası Mehmed Ağa’nın verdiği ziyafetin anlatımından önce veziriazam Osman Paşa'ya dair bir bölüm olduğunu, meslek ehli arasında bozacıların, meyhanecilerin, yeni bedesten (sandal bedesteni) tacirlerinin, Bursa bezirganlarının, gayrimüslim kuyumcuların, süpürgecilerin geçitlerini betimleyen bölümler olduğunu, dolayısıyla bunları tasvir eden resimler olabileceğini öğreniriz. ${ }^{36}$ Arşiv belgesinde bulunmayıp kitapta bulunan başlıkların büyük bölümü padişahın inam ve ihsanlarına, çanak yağmalarına, sazende ve cündilerin geçitlerine, gece gösterilerine, meydanın süpürülmesine, bir başlık da Kızılbaşların ihtidasına dairdir. Bunlar, fihristin kitabın taslak aşamasına ait olabileceğini, resimli yazmaya bu fihristin hazırlanmasından sonra eklenen başlık ve bölümlerin daha çok padişahın cömertliğini vurgulayan ve sarayın düzenlediği gösterilere dair olduğunu düşündürür.

Sûrnâme’nin takdim kopyasından İntizami'nin Hersek'in Foça kasabasından geldiğini, kitabın yazmalarından birinin derkenarında bulunan otobiyografik anlatıdan, bundan önce bir Buda şehrengizi ve bir gazanâme yazdığını öğreniyoruz. ${ }^{37} \mathrm{Bu}$ mahlasla on altıncı yüzyıl tezkirelerine girmemiş olduğundan, hakkında başkaca bir şey bilmiyoruz. Diğer yandan, 1582 şenliğinin sarayla bağlantıları kuvvetli, modern tarihçilere göre de İntizami'den epeyce daha ünlü iki anlatıcısı daha olduğunu - bürokrat, yazar, tarihçi Mustafa Âli ve şehnameci Lokman—göz önüne alırsak, büyük bir yapım olarak planlandığı belli olan, konusu ve tasarımı itibarı ile dönemin resimli kitap üretimi içerisinde bir istisna oluşturan Sûrnâme için neden İntizami'nin metninin seçildiği sorusu üzerinde durabiliriz. Elli iki gün süren ve sarayın başkentte sahnelediği en etraflı, masraflı, şaşaalı tören olan sûrun, Osmanlı ve Batılı başka yazarlar tarafından yazılmış anlatıları da vardır. ${ }^{3}$ İntizami Sûrnâme'sini diğer metinlerden ve özellikle Lokman ve Mustafa Âli'nin anlatılarından ayıran şehirliler üzerine çevirdiği kuvvetli spottur-bu açıdan hem İntizami hem de Mustafa Âli’nin şehrengiz yazarı olmaları dikkate değer. Diğer yazarlar şenliğe ve alaylara katılan göstericileri, esnafı ve diğer meslek ehlini tasvir ederken, İntizami şehirlilerin sesini ve bakışını metne yerleştirir, bunu yaptığının altını da kalınca çizer. Âli’nin Câmi ü’l-buhûr der

almazlar. Prochazka-Eisl Viyana ve Topkapı yazmaları arasındaki üslup farklarının ve Topkapı nüshasındaki şiir eklerinin örneklerini verir; Prochazka-Eisl, Das Sürnäme-i Humāyūn, 29-31.

35 llk sayfalarda bulunan, yine tek sayfalık-ve bir tamir sırasında yanlıs yerlestirilmiș-farklı tarzları itibarı ile yazmanın üretiminde çalışan farklı ekiplere, veya hazırlık mahiyetinde yapılmış resimlerin yazmaya dâhil edildiğine işaret etme ihtimali bulunan resimler de (1a, 7b), kitabın kodikolojisi açısından değerlendirilmelidir. Nurhan Atasoy da yazmadaki 250 meclis göndermesine dayanarak, fakat resimleri tek sayfalık olarak değerlendirerek, toplam 427 minyatür olduğunu belirtir ve en az yetmiş üç resimli varağın kaybolmuş olduğu sonucuna varır, bkz. Atasoy, 1582 Surname-i Hümayun, 14

36 TSMA E1065. Bu belgede olup, TSMK H 1344'de bulunmayan başlıkların önemli bir kısmının yazmanın eksik sayfalarına tekabül ettiklerini düşünüyorum. Fihristin başındaki, Hamd-ı Hüdâ-yı bi-niyâz, medh-i resûl-i kubriyâ, sebeb-i te'lif-i kitâb, müşâvere-i pâdişâh, ta'mirât-ı Atmeydânı ve sarâyhâ, sıfat-ı Osman Paşa, dâvet kerden-i Mehmed Ağa selâtin ra (TSMK H 1344, 2b'de kısmen vardır), ameden-i arabahâ-yı selâtîn be sarây-ı 'atîk, averden-i nahılhâ, seyr-i pâdişâh der câmi'-i sarây-ı 'atîk, der averden-i şeker-kârî başliklı bölümler $\mathrm{H} 1344$ 'de yoktur. Geçitlere dair, fihristte bulunup $\mathrm{H}$ 1344'de bulunmayan, muhtemelen resimli yazmanın eksik sayfalarına tekabül eden baslıklar: bâz ameden-i şehzâde ba nahılhâ-yı buzurg (TSMK H 1344, la'daki nahıl resmi bu anlatiya ait olabilir); der avorden-i nahıl-ı kırtâsî-yi İbrahim Paşa; ameden-i yeki ez zerrâkân-ı dergâh-ı 'âlî; ameden-i horasânciyân; ameden-i carub-sazân; ameden-i ehl-i bezzâzistân-ı cedîd; ameden-i bozacıyân; der avordan-ı ravza-i kırtas-kârî (Topkapı Sarayı yazmasında başlık ve metin kısmen eksiktir, resmin sol varağı mevcuttur, TSMK H 195b-196a); ameden-i kovactyân; ameden-i degirmenciyân ki saz içinde bir adem gizlenüb bası üzerinde değirmen döndürüb un okudurdl; ameden-i cerrârân ve gedâyân (Topkapı Sarayı yazmasında metin kısmen ve resmin bir varağı eksiktir; TSMK H1344, 290a-291a); ameden-i fil-bânân; ameden-i maymunciyân (resimli yazmada başlık ve metin kısmen eksik, resmin sol varağı mevcuttur; TSMK H 1344, 303a-304a); ameden-i balta-kârân; ameden-i zergerân-ı kefere; ameden-i bazargânân-ı Bursa; ameden-i zihgir-trâsânn; ameden-i meyhâneciyân yani küffâr-l hammâr. Fihristin son maddesi "Der tahrîr-i Sûrnâme-i Humâyûn ve sıfat-ı nakkâs ve hatm-i kelâm"dır. Bu belgeye dikkatimi çeken Sinem Erdoğan İşkorkutan’a teşekkür ederim. Resimli yazmanın özgün durumuna dair, bu belgeye de dayanan bir çalışma hazırlamaktayız. 37 Sûrnâme nüshalarındaki otobiyografik anlatılar için bkz. Arslan, Intizâmi, 36-45 ve 486-487; İntizami, Sûrnâme, 43ob-431a. Sözkonusu Buda şehrengizi henüz tespit edilmemiştir.

38 Mustafa Âli, Câmi'u'l-buhûr der mecâlis-i sûr, haz. Mehmet Arslan, Türk Edebiyatında Manzum Sûrnâmeler (Ankara: Atatürk Kültür Merkezi Baskanlığ1, 1999), 333-623; Seyyid Lokman, Sehinşehnâme, c. 2, TSMK, B 200, 32b-86a. 1582 sûrunun Avrupalı anlatıcıları için, Terzioğlu, "The Imperial Circumcision Festival," 97, n. 2; Metin And, Kırk Gün Kırk Gece, 313-319. 
Mecâlis-i Sûr'unun daha yerleşik yazar sesi çoğunlukla olan biteni tasvir eder, zaman zaman şenliğe katılan cemaatlere veya bunların üyelerine hitap ederken (Merhabâ köhne fürûşân-ı cihân / kehle bâzârına sermâye-feşân ${ }^{39}$ ), İntizami şenliğe katılan pek çok esnafa ve göstericiye kendi seslerini verir. Göstericilerin sultana, birbirlerine, seyircilere hitaplarını bazen anlatının parçası olarak, bazen de meydanda seyreden esnafın ağzına yerleştirdiği ve sözünü ettiği gruba veya cemaate göndermelerde bulunan şiirler yoluyla sunar. İntizami göstericilerin ağzından aktardığı pek çok şiiri dönem şairlerinden-bazılarını isimleri ile, bazılarını anonim olarak-aktarmış, kendi eserlerini özellikle belirtmiştir. ${ }^{40}$ Sayısal bir karşılaştırma da, İntizami'nin metnini diğer şenlik anlatılarından ayırır: Oyuncu zümreler dışında yüz yetmiş civarında esnaf cemaatinden bahseden Sûrnâme'ye karşı Âli Câmi'ül'-buhûr'a altmış beş cemaati dâhil etmiştir. ${ }^{41}$ Lokman tarafından yazılıp resimli kopyası 1592'de tamamlanan Şehinşehnâme'nin şenlik anlatıları da benzer bir sonuca ulaştırır bizi: Lokman'ın 1582 şenliğine dair anlatısının yalnızca küçük bir kısmı cemaatlere ayrılmıştır. Ağırlıklı olarak türlü performanslar üzerine odaklanan Şehinşehnâme’nin aktardığ sûr daha çok yüzyıl başlarından itibaren meydanda sergilenmiş, ihsanlar, savaş oyunları, yarışmalar ve gösteriler etrafında kurulmuş şenliklere yakındır. ${ }^{42}$

Sûrnâme'nin son sayfalarındaki "Fermân şoden-i tafsîl-i sûriyye" başlıklı bölümden bir kısım bu kitabı şenliğin diğer anlatılarından ayıran ehl-i hıref ve zanaat odağını belirgin kılar:

[Bu kitap] bir cam-ı cihannümadır ki, yanında Cemşid'in kadehinin yalnızca adı kalır; bir aynadır ki İskender'in aynası onun yanında meydana çıkamadığından kendini nedamet taşına çalar. İki yüz elli bölümü/sayfası meclislerle süslenmiş bir mecmua-i letafet-nümâdır. Meşhurlar meclisinin her bir ferdi Behram Gur'un Havernak-ı heft peykerini dünya yüzünden siler, İrem bağı ne denli yüce olsa da bu bahçenin gerçek şöhreti karşısında utanç içinde kalır, ebediyen gözden kaybolur. Bir şehristandır; ehl-i hırefin tümü yerli yerinde işine oturmuş, zenginler ve ileri gelenler varlarını yoklarını meydana çıkarmışlardır. Ehl-i hüner maharetlerini, nakış ve suret ashabı nezaketlerini ortaya çıkarmıştır. Her kalenin, şehrin, kasabanın köylü ve şehirlileri birbirlerine üstünlüklerini göstermek üzere işlerini var güçleri ile ortaya koymuşlar; işbilirler ve tacirler alışverişin ne yoldan yapıldığını sergilemişler. [Bu kitap] dünyanın tüm ziynetlerini barındıran büyük bir hazine, kâinatın tüm inci ve yakutunu, denizlerin ve karaların define ve hazinelerini barındıran bir sandıktır. Mahir bir bahçıvanın dört mevsimin ağaçlarını bir gövdeye aşılayarak yetiştirdiği, padişahın lütfu ile büyüyüp serpilmiş tuba benzeri bir ağaçtır; yaprakları, meyveleri ve dalları evrenin her köşesine yayılmış, şehinşahın can veren lütuf ve merhameti sayesinde, yazın ve kışın tüm çiçeklerini tek bir mevsimde açmıştır. Ve nihayet [Sûrnâme] seri-ül beyan bir tercümanın kalemidir: yetmiş iki dili değil, 250 ehl-i hıref ve sanayinin başka başka lisanlarını, her birini kendi dillerine ve tarzlarına göre beyan eder; ahenkle ve kusursuz yazan bir Attar'dır ki, Mantıku't-Tayr usul ve füru'unu takib ederek ekserisi ile aynı dilden konuşur. ${ }^{43}$

39 Âli, Câmi'u'l-buhûr, 420 .

4o İntizami'nin alıntılar yaptığı şairler için, Arslan, Intizâmi, 65. Diğer nüshalara göre daha uzun bir metin içeren Topkapı Sarayı nüshasında şiir alıntılarına da daha fazla yer verilmiştir.

41 Mehmet Arslan Sûrnâme'de 173 esnaf alayı sayıyor; Arslan, Intizâmi, 8o-86. Gisela Procházka-Eisl 1582 sûrunun Intizami, Âli ve Nicolas Haunolth anlatılarındaki sayıları karşılaştırarak İntizami Sûrnâme’sinin Viyana kopyasında bahsi geçen 177 zümrenin en yüksek sayı olduğunu belirtiyor, ancak Topkapı Sarayı nüshasındaki eksik varaklarda bulunabilecek esnafı dikkate almıyor; Procházka-Eisl, "Guild Parades," 43-45. İntizami esnaf cemaatlerini ve gösteri yapanları belirgin olarak ayrıștırmadığından, bu sayıyı kesinleștirmek zordur. Mehdi Keyvani 1504 tarihli, Herat'ta yazılmış bir fütüvvetnâmenin zanaatkârları ahl-i ma'raka ve ahl-i kabza, yani göstericiler ("meydan ehli” olarak çevirebiliriz; meddahlar, güreşçiler, hokkabazlarla birlikte sakalar ve hamallar) ve el işi yapanlar olarak ikiye ayırdığına dikkat çekiyor. İntizami'nin şenliğin tüm katılımcılarını ehl-i hıref olarak tanımlamasının ve Sûrnâméye ikiyüzelli ehl-i hıref cemaatini dahil ettiğinden bahsetmesinin ardında hüner ehlinin böyle bir tanımı olabilir; Mehdi Keyvani, "Artisans and Guild Life in the Later Safavid Period," (doktora tezi, Durham University, 1980), 246-248. Evliya da lu’bedebâzân, sazendegan ve mudhikan taifelerini esnaf alayları anlatısına dahil eder, başka bir bağlamda oyuncu taifesini zikreder; Evliya Çelebi, Seyahatnâme, c. 1, 164, 347-349. On yedi ve özellikle on sekizinci yüzyılda oyuncu tarifesinin şenliklere katılan esnaf arasında ayrıştırılması ve 1720 şenliğinde oyuncu kollarına dair belge ve anlatılar için bkz. Erdoğan Isskorkutan, "The 1720 Imperial Festival," 263-94.

42 Seyyid Lokman, Sehinşehname, c. 2, 32b-86a. I. Süleyman dönemi şenliklerinin dönemin siyasi kültürü açısından değerlendirmesi için, Yelçe, "Evaluating three imperial festivals"; Kaya Şahin 1530 şenliğini siyasi dinamiklerle birlikte gösterimsel boyutu açısından tartışır; Şahin, "Staging an Empire."

43 "bir câm-1 cihân-nümâdır ki 'amel-i Cemşî̀d yanında bir kuru nâmı kalmıș ve bir âyînedür ki mirâte-1 ìskender yanında sûret pezîr olmadugı ecilden özin seng-i nedâmete çalmıș. Ve bi'l-cümle bu mecmû'a-i letâfet-nümânun iki yüz elli 'aded her safhatın mecâlisle zînet-pezîr ve encümen-i şöhret-esîrün firâden her biri Behrâm-1 Gûr'un havernak-1 heft-peykerin sahîfe-i 'âlemden mavh idüp zâyil eder ve hadîka-1 şöhret-esâsı bâg-1 İrem ne denlü Şeddâdî binâ ise göstermekden kat'-1 nazar idüp tâ ebed hicâb içinde kor gider. Bir şehristândur ki cemî́an ehl-i hıref yerlü erinde işine oturmuş ve erbâb-1 zîb ü şeref mâ-meleklerin ve nakd-i vaktlerin maydâna çıkarup ortaya getürmüş. Her ehl-i hüner mahâretin zuhûra ve ashâb-1 nukuş u suver nezâketin sudûra irgürmüş. Kılâ‘ u bikâ‘ ve bilâd u kasabâtun dîhî vü șehrî ne mu'âmelesi var ise birbirine galebe yüzinden var kuvvetlerin bâzûya ve ashâb-1 çûn u çirâ ve erbâb-1 bey' u şirânun alışı ve verişi ne tarîk ile oldugı nezâketi cümleten terâzûya getürmüşler. Bir derc-i 'azîmdür ki cihânun cemîân zîb ü zîveri içinde münderic ve bir dürc-i güzîndür ki leâlî vü yevâkît-i kevn ü mekân ve defâyin ü hazâyin-i bahr u kân derûnında mümtezic. Bâg-bân-1 heme-i mahârettibyân bir mevsimde fusûl-i erba'anun esmârın bir kaleme aşılayup tûbâ misâl berg ü bârın ve agsânın kevn ü mekâna salup neşv ü nemây1 lutf-1 pâdisâhî ile bir anda yetişdürmüs ve sayf u șitânun envâ'-1 ezhârın hevâ-yı cân-fezâ-y1 mekrümet-i șehenşâhi ile bir mevsimde irişdürmüş. El-hak hâme-i serî́ü'l-beyân bir tercemândır ki yetmiş iki dil bilmek degül iki yüz elli ehl-i hıref ü sanâyi'un zebânı ki birbirine 1stılâhât yüzinden mütegâyirdür, firâden dillerince edâ-y1 garîbe ile beyân itmiş ve 'Attar-1 fesâhat-bünyândur ki Mantıku't-Tayr usûl u 
Bir cam-1 cihannüma ve bir ayna, bir mecmua, bir hazine, bir şehristan, dört mevsimin ağaçlarından aşılanmış bir cennet ağacı, iki yüz elli ehl-i hıref ve sanayinin dillerini aktarmaya kâdir seri'ü-l beyan bir tercümanın kalemi: İntizami’nin Sûrnâme için kullandığı her benzetme ve çağrıştırdığı her imge bu eserin kalabalık çok sesliliğine bir göndermedir. Hanedana, padişaha ve kitabın yazılıp resimlenmesine aracılık eden saraylı amillere övgüler içeren mukaddime ve sonuç kısımlarının arasında, bu uzun eserin büyük kısmı şenliğe katılan göstericilere ve daha çok da meslek ehline ayrılmıştır.44

\section{Seyir ve Temaşa, Nazar ve Bakma Hakkı}

Birkaç istisna dışında tüm resimler aynı hiyerarşik düzene göre kurulmuşlardır: Yatay olarak bölünmüş resim alanının üst kısmında sol varakta sultan ve şehzade, sağ varakta ve biraz aşağıda seçkin konuklar, alttaki yatay şeritte geçit yapan esnaf ve diğer meslek ehli, gösteri yapan çeşitli zevat ve bunları seyredenler vardır. ${ }^{45}$ Dikey hat üzerine kurulu bu hiyerarşi okurun gözü hareket ve çeşitlilik üzerinde odaklandığında altüst olur. Sezer Tansuğun Şenlikname Düzeni’nde çeşitlilik ve süreklilik kavramlarının yazmadaki işleyişini merkeze alarak ve incelikli gözlemlerle tartışmış olduğu gibi, resimlerin görsel odağı meydanın kalabalık, değişken ve çok odaklı temsilidir. Çoğu aynı kalıptan kopyalanarak resmedilmiş, her bir sayfada renk ve detay farklılıklarıyla tekrarlanan ve dolayısıyla bir hareketsizlik ve donmuşluk izlenimi oluşturan sultan, şehzade ve seçkinlerin betimlemeleri, durağan bir arka planın parçalarıdır. ${ }^{46}$ Resim odağının sultana, hanedanın erkek üyelerine, seçkinlere veya edebi anlatıların kahramanlarına ayrılagelmiş merkezini Sûrnâme'de ilk defa ve kuvvetle esnaf ve başka şehirli zümreleri, çeşitli meslek ehli ve gösteri yapanlar işgal eder. Sol varağın alt kısmında bulunan ve her resimde aynı boyutlara sahip bir dikdörtgen çerçeve (sınırlarını üstte saray duvarı, yanlarda ve altta varak kenarları belirler), resmin diğger alanlarından bir derece ayrıştırılmış ana odağını oluşturur (şek. 11, 12). Bu çerçeve içerisinde ressamların bir önceki yazı varaklarında başlığı bulunan konuya dair görsel seçimlerini izleriz: dükkân modelleri, sergilenen eşya, çiftler halinde ilerleyen usta ve çıraklar. Sağ varağın bu kademesi nispeten daha serbest bir kompozisyona sahiptir, geçide katılan diğer bireyleri ve eşyayı, sağ kenar boyunca da kadın, çocuk ve çoğunlukla erkek seyircileri barındırır.

Sûrnâme'deki Atmeydanı, hem saray hem şehir mekânı, ama aynı zamanda bu alanların sınırlarının müzakere edildiği, elit ve şehirli öznelliklerin ifade bulduğu yerdir; kitap ve ressamları temaşayı betimlerken, göstericiler, seyirciler, meslek ehli, arzu nesneleri olarak şehirli aktörleri önceler. Sûrnâme metni ve resimleri, hükümdar, seçkinler ve şehirliler nezdinde meydanın performatif inşasına işaret eder. Resimleri yatay bir hat üzerinden ikiye bölen çizgi, hegemonik bakışın durağanlığını sokak bakışının hareketlilik ve değişkenliği ile karşı karşıya getirir. Şenlik anlatısının tümünde her iki varakta bir, iki yüzden çok defa tekrarlanan bu şemayı saray ve şehir perspektiflerinin karşılaşmasının ve bir aradalı̆̆ının ifadesi olarak okumak mümkündür.

Birbirine sıkı sıkıya örülmüş sözel ve görsel anlatıları ile Sûrnâme’yi nazar, seyir ve temaşanın çoğul anlam yelpazelerini kucaklayan yeni bir çerçeve olarak okuyabiliriz. Bakışı hareketle ve bedenle örtüştüren, hareket halindeki gözü (ve bu gözün imkânlarını) herhalde en kuvvetle yakalayan seyir ve yine hareketi günümüzdeki anlamı ile seyretme ile, seyredilen yer, manzara,

fürû́1 ile hâtır-nişân itmekle ekseri ile hem-zebân olmuş.” İntizami, Sûrnâme, 430b-431a; Arslan, Intizâmi, 488-489.

44 Kesin ve kategorik ayrımlar yapamasak da, resimlerin konularına göre sayısal bir dökümü de yine kitabın ehl-i hıref ve daha geniş anlamda șehirliler odağını görünür kılar. Kitapta günümüze ulașan 224 resimden 137'si meslek ehlinin geçitlerini-saraylı ve șehirli ayrımı yapmadan-tasvir eder. Sadatın, çeşitli tarikat ehlinin, suhtelerin, Hristiyanların alaylarını tasvir eden resimleri de çoğu şehirli halka mensup "zümreler" kaleminden saymak doğru olabilir. İntizami göstericileri de hüner ehli olarak görmüş, sayılarını iki defa zikrettiği 250 ehl-i hırefin toplamına savaș oyunlarını, gece gösterilerini düzenleyenleri, cambazları da dahil etmiş olmalıdır (bkz. dipnot 41). Sultanın, hanedanın ve seçkinlerin meydandaki varlığını önceleyen resimler nispeten az sayıdadır: Kitabın bas ve son sayfalarındaki on bir resim sûrun başlamasına, bitişine, kitabın yapımına ve sunulmasına dair temsiller içerir, şenlik anlatısına dair altı resim padişahın ihsanlarını, şenlik sırasındaki çanak, altın ve gümüş yağmalarını temsil eder.

45 Sûrnâme resimlerinin hiyerarşik yapısında 1ll. Murad'ın merkeziliğinin altını çizen ve kitabın üretiminde harem ağaları Zeyrek ve Mehmed Ağa’ların rolüne dikkat ceken bir değerlendirme için, Fetvacı, Picturing History, 175-185.

46 Tansuğ bu temel kompozisyonun esin kaynağını Atmaydanı'nda, İmparator Theodosius tarafından dikilmiș olan obeliskin kaidesinin dört yüzünde bulunan, imparatoru, maiyetini ve göstericileri içeren rölyeflerde bulur. Aynı çalışmada, resimlerin süreklilik ve çeşitlemecilik üzerine kurulu anlatı yapısının ressamların yaptığı temsili seçimler açısından kapsamlı bir tahlilini sunar; Tansuğ, Senlikname Düzeni, özellikle 91-137. Bu mekânsal düzen aynı zamanda bu yılların saray konulu resimlerinin düzenini de çağrıștırır: Dikey bir hat üzerinde görselleștirilen bir hiyerarșiye göre sultanı resmin üst kısımlarında bir köseye yerleștiren, anlatının merkezindeki diğer figürleri görsel odağa alan, örneğin Hünernâme ve Şehinşehnâme resimlerini hatırlayabiliriz; Bağcı et al., Osmanlı Resim Sanatı, 140-152. 
24 şey veya gösteriyle örtüştüren temaşa (dolayısıyla seyr ü temaşa) üzerine kurulu anlatı ve tasvirleri, ayrıca daha da geniş ve karmaşık bir semantik alana sahip, görmeyi zihinsel boyutları ile ilişkilendiren, aynı zamanda sahiplenme (ve yok etme) edimleriyle bağlantılı nazar izleklerini İstanbul ile ilgili Osmanlı metinlerinde on beşinci yüzyıl sonlarından itibaren takip edebiliriz. Seyir ve temaşanın tarihi henüz layıkıyla üzerinde durulmamış bir etimolojik bilmeceyi de barındırır: Arapçada gezmek, yürümek, seyahat, deniz yolculuğu anlamlarını barındıran seyir ve yine gezme, yürüme anlamı taşıyan bir kökten türetilmiş, birlikte yürüme anlamında da kullanılan temaşanın Farsçada ve Türkçede görme, "haz ve sefa ile" veya "ibret ile" seyretmeyle, bunlarla bağlantılı olarak da gösterimle ilişkilendirilmesinin tarihini bilmiyoruz. Hareketi ve hareket halindeki bedeni görmeyle ve nihayet gösteriyle ve manzarayla örtüştüren bu fiillerin özellikle on altıncı yüzyıl ve sonrasında yaygınlaşmış olmalarının üzerinde durmaya değer. ${ }^{47}$ Lokman'ın, Atmeydanı'nda kadınlar hikâyesinde kullandığı "akışu akışu temaşaya bakışugiderler" ifadesi birlikte yürüme ve bakma edimlerini, kaybolmuş bir birleşik fiil aracilığılla, bir araya getirir. Sözlüğünü on yedinci yüzyıl sonlarında tamamlayan Meninski'nin uzun ve kapsamlı "temaşa" maddesindeki ilk anlam "birbiri ile yürüşmek" iken, gösteri ve seyre dair çeşitli kullanımları arasında "bünyan temaşası"nı da buluruz. ${ }^{48}$

Bu kelimeler ve kavramlar kümesini bir arada, döneme ve yere özgü görme şekillerinin farklı ve ilişkili boyutları olarak düşünmek, mekânı ve mekânın görselliğini anlamak açısından verimli olabilir. Nazara ve seyre dair metinler bakanın öznelliğini varsayan, bir yandan da şehre yerleşik, mekânla bağları kuvvetli tasvir ve anlatılardır. İslami dünyada ortaçağlarda formüle edilen, bakan özne ve bakılan nesne arasındaki ilişkiyi çok boyutlu olarak kurgulayan, bakış açılarının çoğulluğunu varsayarken buna bağlı olarak görülen alanı-veya mekânı-onu oluşturan parçalara bölerek gözün öznelliğini ve hareketliliğini vurgulayan görme, algılama ve tahayyül etme kavramsallaştırmalarının izlerini taşırlar. ${ }^{49}$ Ama aynı zamanda erken modern döneme ve özellikle İstanbul'un fiziki ve sosyal topografyasına, siyasi bağlamına özgü görsellik pratiklerini yansıtırlar..$^{\circ}$ Belli noktalardan görülen manzaralar ve belli yerleri çerçeveleyen nazargâhlar, görsel ve bedensel anlamda 'seyir yerleri' olan mesireler, seyredilen (geçilen, yürünen) yeri, binayı, olayı veya gösteriyi imleyen temaşagâhlar, mimari mekânın algılanışında hareket halindeki bedeni ve hareket halindeki gözü önceleyen "bünyan temaşası," bakışın ve seyrin mekânla örtüştüğü başka başka bağlamlara işaret eder.

Görsellik odaklı bu kilit kavramların Sûrnâme metnindeki ve resimlerindeki anlamlarını, Derin Terzioğlu'nun 1582 şenliği için sunduğu Bakhtin esinli yorumla birlikte düşünmek mümkün. Saraylı ve şehirli, şehirli ve köylü, yerli ve yabancı, daha kısıtlı bir derecede de olsa kadın ve erkek arasında dikkatle korunan sınırların ve hiyerarşilerin belirsizleştiği, siyasanın ve toplumun

47 Seyr (s-y-r kökünden) ve temaşa (m-ş-y kökünden) Arapçada gezme, seyahat, yürüme fiillerini karşlar. 1545 tarihli Arapça-Türkçe sözlük Ahterî-i Kebir'de seyr kelimesinin bakma ile bağlantısına dair bir ipucu yoktur; bkz. Ahteri Mustafa Efendi, Ahteri-i Kebir (Dersaadet: Matbaacı Kemal Efendi, 1324/1906-1907), 532. Ortaçă̆ Anadolu Türkçesi'ne dair sözlük çalışmaları ve örneğin Yunus Emre Divanı da, bu dönem Türkçesinde seyrin bakma ile bağdaştırılmadığını düşündürür; Mehmet Kanar, Eski Anadolu Türkçesi Sözlüğ̈̈ (İstanbul: Say, 2011), 597; Yunus Emre Divanı, haz. Mustafa Tatçı (Ankara: Kültür ve Turizm Bakanlığı, 1990-91). Yunus Emre'nin seyri ve seyranı düşle bağlantılandırması görme anlamına belki en yaklașan kullanımıdır; bkz. 247,361. Seyirin genişleyen manası üzerinde dururken Nesimi'nin "Kah çıarım gökyüzüne seyrederim alemi / Kah inerim yeryüzüne seyreder alem beni” dörtlüğünü bana hatırlatan Cemal Kafadar’a teşekkür ederim. Yunus'un ve on beşinci yüzyıl başlarında Nesimi'nin dizeleri seyrin bakış ve müşahede ile bağdaşmasının bir boyutunu kelimenin tasavvufi anlamlarında arayabileceğimizi düşündürüyor. 168 o tarihli Meninski sözlüğünde ve Mertol Tulum'un, Meninski'yi ve Seyahatname'yi de kaynak alan on yedinci yüzyıl İstanbul Türkçesi sözlüğünde seyir ve temaşanın birçoğunu bugün de tanıdığımız çoğul anlamlarını buluruz; Franciszek Meninski, Thesaurus linguarum orientalium Turcico-Arabico-Persicae: Lexicon Turcico-Arabico-Percicum haz. Stanislaw Stachowski (İstanbul, Simurg, 2000), 1380-1381, 2729-2730; Mertol Tulum, Meninski'nin Thesaurus'u ve XVII. Yüzyll İstanbul Türkçesi (Ankara: Türk Dil Kurumu, 2011), 1583-84, 1743. Temaşanın haz ve sefa ile veya ibret ile nazar etme anlamı için Mütercim Asım Efendi, Burhân-ı Katı, haz. Mürsel Öztürk ve Derya Örs (Ankara: Türk Dil Kurumu, 20oo), 761.

48 Meninski, Thesaurus linguarum orientalium, 2730. Nicholas Kontavas'a bu kelimenin yapısı ve etimolojisi üzerine bilgisini benimle paylaştıgı için teşekkür ederim.

49 Gülru Necipoğlu ortaçağ İslam dünyasında bilimsel ve felsefi çerçevelerde geliştirilen bakma ve algılama kavramlarını ortaçă̆larda ve erken modern dönemde görsel kültür ve özellikle figüratif ve figüratif olmayan sanat üretimi ve algısı açısından irdelemiștir. Bakışın estetik, duyusal ve bilişsel boyutları üzerinde duran bu çalışma, sanatçının ve seyircinin öznelliğini ve failliğini barındıran çok-perspektifli bakma şekillerinin, sanatın (özellikle resim ve mimarinin) kavramsallaştırılması ile bağlantılarına 1şı tutar, bkz. Gülru Necipoğlu, "The Scrutinizing Gaze in the Aesthetics of Islamic Visual Cultures: Sight, Insight, and Desire," Muqarnas 32 (2015): 24-61. Aziz al-Azmeh bakışa ve imgeye ilişkin kavramları ve görsellik pratiklerini ortaçağ İslam kültürü çerçevesinde tartışır, bakmayı ve algıyı duyusal ve zihinsel boyutları ile açıklayan çerçevelere dikkat çeker; Aziz al-Azmeh, "Preamble," The Medieval History Journal 9 (2006): 17-36.

50 İstanbul'un fiziki ve sosyal topografyasına özoü görme biçimlerinin mimarlık ve şehir dokusu ile bağlantıları için, Orbay, "Istanbul Viewed”; Gülru Necipoğlu, Sinan Çağı: Osmanlı Imparatorluğunda Mimarî Kültür (İstanbul: Bilgi Üniversitesi, 2013), özellikle 140-153; Kafescioğlu, Constantinopolis/Istanbul, özellikle 130-142. Erken modern dönem İstanbul'u bağlamında seyir ve temaşa kavramlanı ve pratikleri için, Cemal Kafadar, "Eremya Çelebi Kömürciyan'ın Kamera öncesi Kamerası," Altyazı Sinema Dergisi 15o (Haziran-Eylül 2015): 78-79; Senem Aytaç, Zeynep Dadak ve Berke Göl, "Kamera öncesi bir Kamera Gezisi: Cemal Kafadar ile söyleşi," Altyazı Sinema Dergisi 109 (Eylül 2011): 48-55; on sekizinci yüzyll İstanbul'unda seyr ü temaşa ve seyir yeri olarak mesireler üzerine bkz. Shirine Hamadeh, Şehr-i Sefa: 18. Yüzyılda İstanbul (İstanbul: íletişim, 2010). 
Şekil 8: "Pâpûș-1 sipâhiyân işler şehirlü tâ'ifesi." Nakkaş Osman ve atölyesi, İntizami, Sûrnâme, TSMK H 1344, 1588, $247 \mathrm{~b}-248 \mathrm{a}$. yerleşmiş ve temsil edilen düzeninin şenliğin tespit edilmiş süresi boyunca altüst olduğu karnavalvari ortamda, seyir ve nazar izlekleri Sûrnâme yazarının ve ressamlarının şenliğin görsel ve mekânsal boyutlarını temsil etmelerine de aracilık eder..$^{51}$ Intizami, göstericilerin ve seyircilerin, sultan ve tebaanın karşılaşan ve kesişen bakışlarını (ve sözlerini) meydanın dikey ve yatay hatları üzerinde takip ederken, Nakkaş Osman ve nakkaşhane ressamları seyir izleğini görselleştirir. Ma'reke-ârâlar (meydanı süsleyenler) her koldan gelip seyr ü temaşaya dururlar; seyir ehli der ü dıvara tıka basa dolar.52 Sipahi için pabuç yapan şehirli taifesi "birbirine 'iğneden ipliğe dek biz bu seyrün râgıbıyuz' deyu güftâr” eder (şek. 8). Seyrin hareketi ve görmeyi içeren çoğul anlamları üzerine kurulu bu tek cümle dikkat çekmeye çalıştığım olguyu özetleyiverir: Seyir nesneleri ve seyirciler olarak meydanda seyreden (görenler ve görülenler olarak meydandan geçen) șehirli pabuççular aynı anda her üç edimin "râgıbı," "isteklisi"dirler. ${ }^{33}$ Resimler, farklı toplumsal katmanlara işaret eden alanlar-ve bu alanlarda meskûn öznelerarasındaki bakışları ve seyri tasvir eder. Nazargâhın (metne göre "nazargâh-1 şâh-1 cihânpenâh") ve buradan meydana bakan sakinlerinin (resimlere göre IIl. Murad, Şehzade Mehmed ve hasoda ağaları) Sûrnâme metninde ve resimlerinde mekânsallaştırdığı güç ve sahiplenme ifadesi açıtır. ${ }^{54}$ Ama Sûrnâme'de aynı zamanda seyir eyleminin görsel ve bedensel boyutları ile

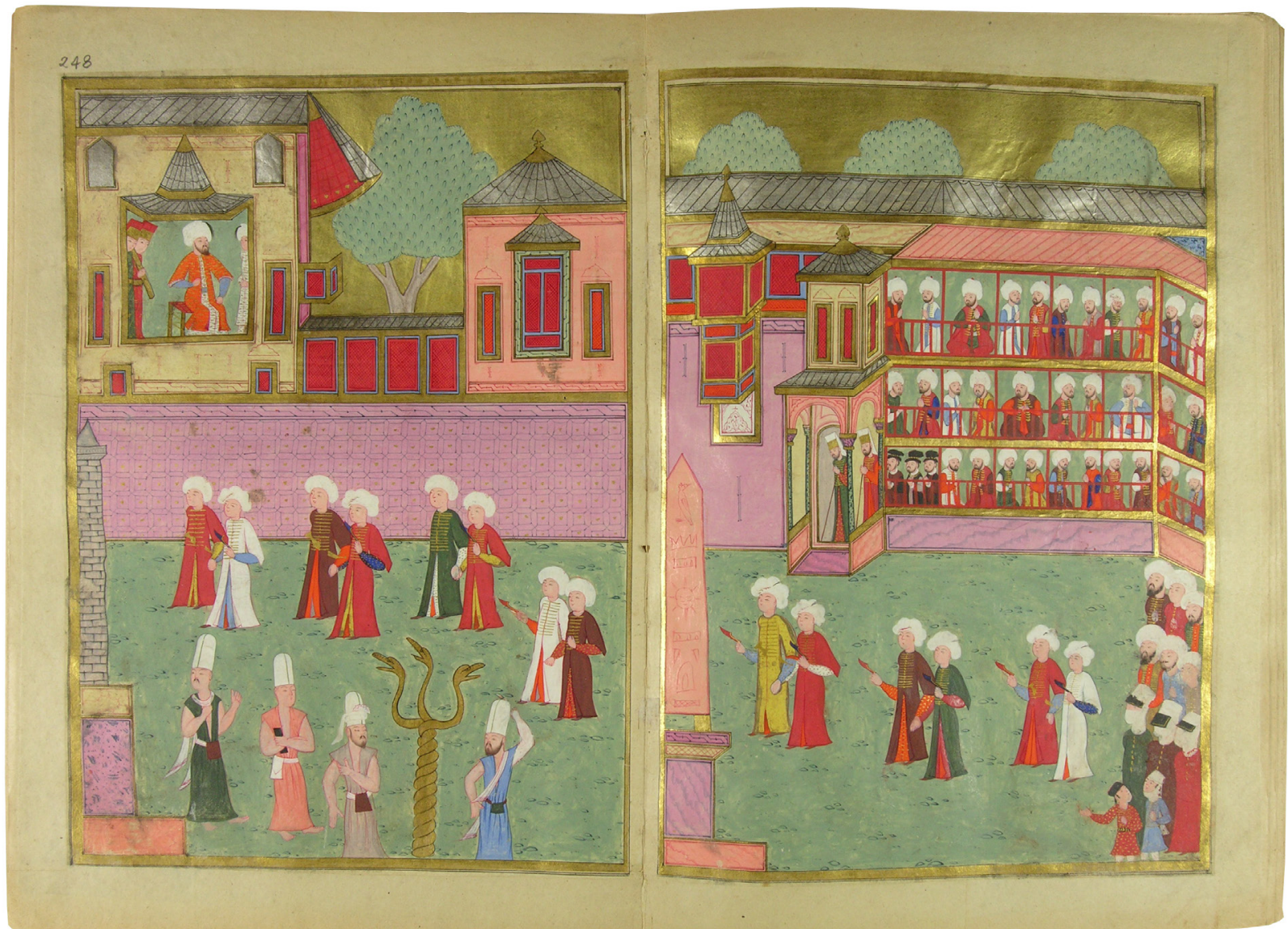

51 Terzioğlu, “The Imperial Circumcision Festival,” özellikle 91-97. Diğer yandan, bu yazıda, altüst olma halinin (ve görsel ve mekânsal boyutlarının) șenliğin ötesinde de varlığı ve anlamı olduğunu öneriyorum; yazının üçüncü kısmında, bu öneriyi daha açıklıkla ortaya koymaya çalışacağım. Kaya Sahin, Sultan Süleyman döneminde yine Atmeydanı’nda gerçekleșen 1530 sünnet senliği bağlamında şenliklerin gösterimsel boyutuna, sultandan en alt düzeylerdeki kişilere kadar geniş bir yelpazede tüm katılımcıların varlığını, edimlerini ve etkileşimlerini içeren, grup aidiyetlerinin ifade bulduğu olaylar olduğuna dikkat çekiyor. 1530 ve 1582 şenliklerinin tasarımı ve temsilleri arasında önemli farklar olmakla birlikte gösterimin katılım boyutuna dair bu gözlemler burada sunduğum çerçeve ile bazı paralellikler içeriyor; Sahin, "Staging an Empire," özellikle 464 ve 472-473.

52 İntizami, Sûrnâme, 27b; Arslan, Intizâmi, 144

53 "Pâpûş-1 sipâhiyân işler şehirlü tâ'ifesi," İntizami, Sûrnâme, 247a; Arslan, İntizâmi, 338.

54 Sûrnâme resimlerinin sultanın ve iktidarın temsilini önceleyen bir okuması için, Fetvacı, Picturing History, 175-185. Osmanlı ve erken modern İslam dünyası bağlamında güç ve sahiplenme ifadesi olarak nazar/bakış ve özellikle saray mimarisindeki izdüşümleri için, Gülru Necipoğlu, 15. ve 16. Yüzyılda Topkapı Sarayı: Mimari, Tören ve İktidar, çev. Ruşen Sezer (İstanbul: Yapı Kredi, 2014); "Framing the Gaze in Ottoman, Safavid, and Mughal Palaces," Ars Orientalis 23 (1993): 303-342. 
barındırdığı sahiplenmeyi ve hazzı; bu karmaşık yapılı gösterimin-örtüşen ve sürekli birbirine dönüşen-seyreden ve seyredilenleri açısından yarattı̆̆ı muğlaklıkları da takip edebiliriz. Sûrnâme resimlerinin ilanihaye tekrarlanır görünen çerçevesi içinde çoklu seyir eksenleri vardır: Resimlerin önemli bir kısmında meydandan geçen göstericilerin ve zanaatkârların dairesel rotaları yüzlerini önce hünkâr köşküne, sonra seyircilere doğru yönlendirir. Gösteri konulu her imge meydanın en sağında, bazen bir erkekler grubu olarak, bazen kadınlar ve çocuklarla birlikte betimlenen seyircilerin göstericilere doğru bakışını betimler; seyircilerin hünkâr köşküne dönük, hünkârın seyircilerin bulunduğu alana dönük yüzleri bakışlarının karşılıklılığını resimler. Şenliğe göre düzenlenen meydanın mekânsal kurgusu kadar, bu kurgunun edebi ve görsel temsili de, hiyerarşik bir düzen içerisindeki mütekabiliyeti ve farklı öznelliklerin ifadelerini barındırır (şek. 7-10).

Muktedirin bakışını ve bu bakışın mekânsal-mimari çerçevelerini siyasi gücün ve otoritenin ifadeleri olarak okumayı öneren yorum çerçeveleri bir yandan da muktedirin nazarına maruz kalan kişilerin, yerlerin, şeylerin nazarda ifade bulan güç ve sahiplenmenin edilgen kabullenicileri olduğunu varsayar. ${ }^{55} \mathrm{Bu}$ varsayım tartışma konusu edilmiştir gerçi, fakat göze ve bakışa dair dinamikleri özellikle kent mekânı bağlamında düşünmek de, bu olguları çok katmanlı olarak anlamanın yollarını sunacaktır. Bu yazı, nazarın/bakışın, kentsel mekânda ve görsel temsildeki varlığının ve işleyişinin çok eksenli ve çok katmanlı olarak anlaşılabileceğini varsayıyor; şehir mekânı kadar, burada konu edilen dönemin şehir odaklı temsillerinin de bu yönde bir yoruma açık olduğunu öneriyor. ${ }^{56} \mathrm{Bu}$ öneriyle metinlere dönecek olursam: İntizami, başka öznellikler aracılığı ile, bakışı hükümdarın öznelliğinin ötesinde okuma olasılıklarına işaret eder; hünkâr köşkünün karşısında maharetini sergileyen bir ip cambazının ağzından, seyir ve iktidar arasındaki karşılıklı ve karmaşık ilişkiye atıfta bulunur. Seyredenler ve seyredilenler, nazar sahipleri ve nazara maruz kalanlar arasındaki ilişkilerin tek yönlü ve tek boyutlu olmadığını hatırlatır:

\section{Bi’z-zât pâdişah oturup seyrim eyleye}

Sarf itmeyem mi böyle deme iktidârımi ${ }^{57}$

Seyr ü temaşanın hünkâr köşünde ve hükümdarda cisimleşen otoriteye ve meydandakilerin öznelliklerine göre temsili, Nicholas Mirzoeff'in formülasyonu ile düşünecek olursak meydandakilerin "bakma hakkı"na, iktidarca tanımlanan görsel düzen dışında var olan ve muktedire yöneltilen nazara dikkat çeker. Meydanda, hükümdarın sahiplenici bakışı cambazın gösterisinden kaynaklanan kendi iktidarı-ve iktidarı konusundaki farkındalığıile karşı karşıyadır..$^{8}$ (En az iki kapsamlı tamirden geçmiş görünen Sûrnâme yazmasını bilmediğimiz bir tarihte onaran vassalın tam da bu anlatıyı takip eden sayfalardaki cambaz tasvirlerinden birini alıp, sonraki bir sayfada padişahın oturduğu köşeyi tamamlamak için kullanmış olması-herhalde yırtılmış olan-hükümdar imgesinin yerine cambazı yapıştırması ilahi bir tesadüf eseri midir, yoksa kasıtlı bir yeniden yerleştirme midir, bilemeyiz. $\left.{ }^{59}\right)$ (şek. 9, 10) 
Şekil 9: Cambaz. Nakkaş Osman ve atölyesi, İntizami, Sûrnâme, TSMK H 1344, 1588, 29b-3oa. Resmin eksik sol varağının bir parçası varak 135a'dadır.

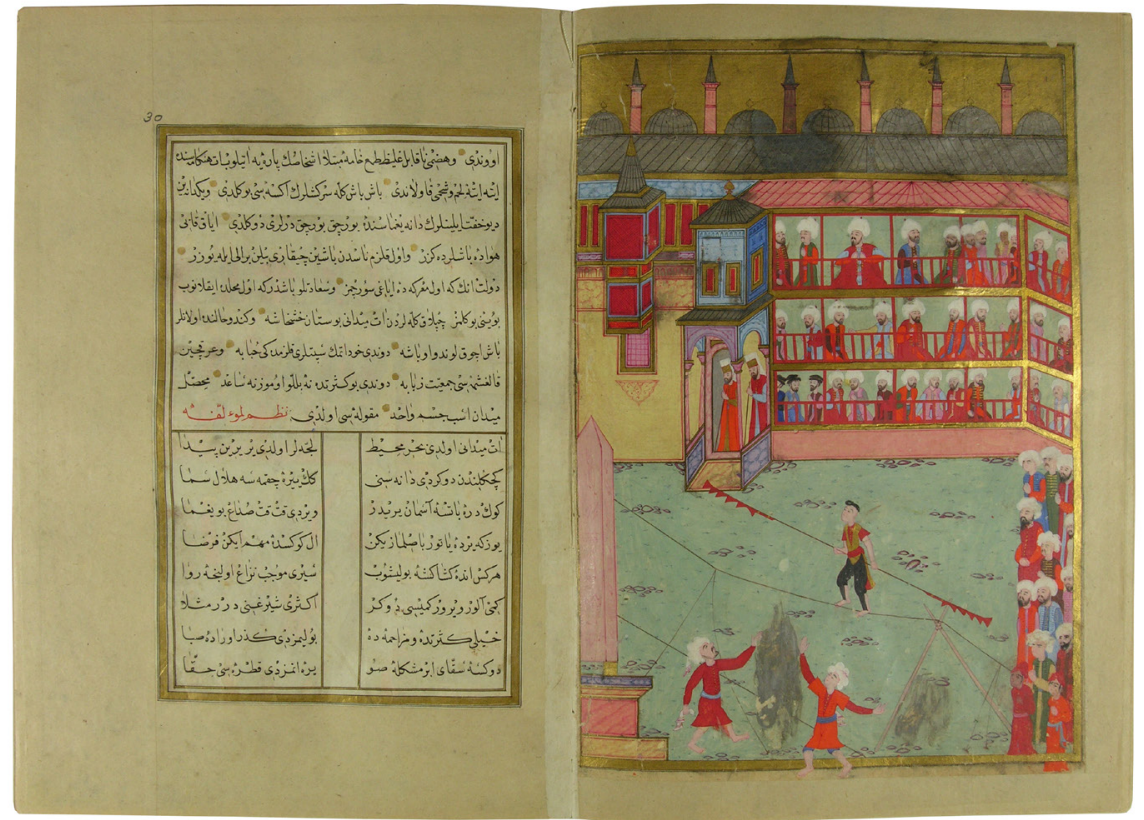

Şekil 10: Kalaycıların geçidi:

III. Murad'in bulunduğu sol üst köşe yazmanin 29b varağında bulunan cambaz gösterisinin solundaki varaktan kesilmiş, yine bir cambazın betimlendiği bir parça yapıştırılarak tamir edilmiş. Nakkaş Osman ve atölyesi, İntizami, Sûrnâme, TSMK H 1344, 1588, 134b-135a.
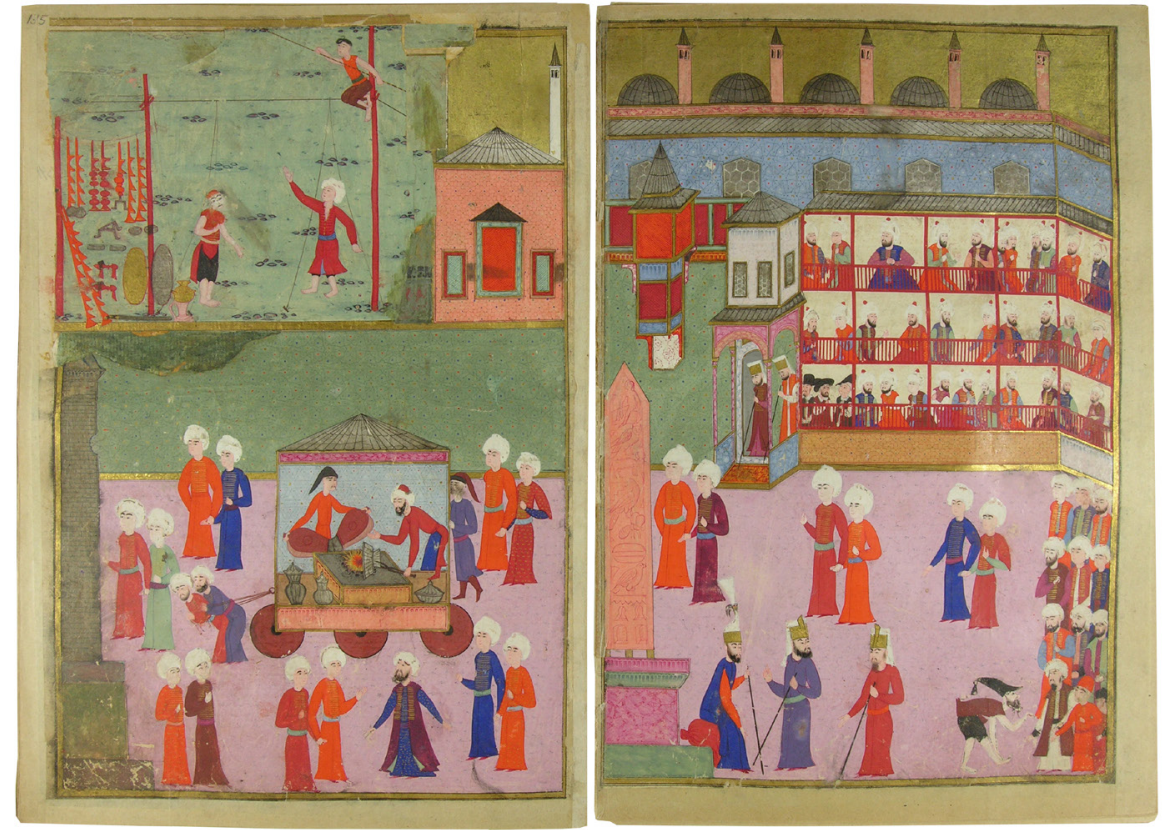

\section{Şehirliler, Eşya ve Yeni Kamusallıklar}

Sûrnâme'deki seyir ve temaşanın bir öznesi cambazların, cündilerin, güreşçilerin, hokkabazların, ateşbazların, başka diğer hüner sahiplerinin gösterileri; savaş temsilleri; nahıl geçitleri; geceleri yapılan fişek gösterileri; sazendegân ve hanendegânın, alaylara katılanların performansları; bazen onlara eşlik eden derviş gruplarının sema ve devranlarıdır; diğer öznesi de güzelliklerine, endamlarına beyitler düzülen civanlar, dilberler, mahbuplar, "düğün bahânesiyle cüvânânı seyr," "mahall-i 'ayş ü 'işreti kat kat seyrân"dır. ${ }^{60}$ İntizami'nin alay anlatıları bir yandan cemaatlerin ve seyircilerin yüzler 

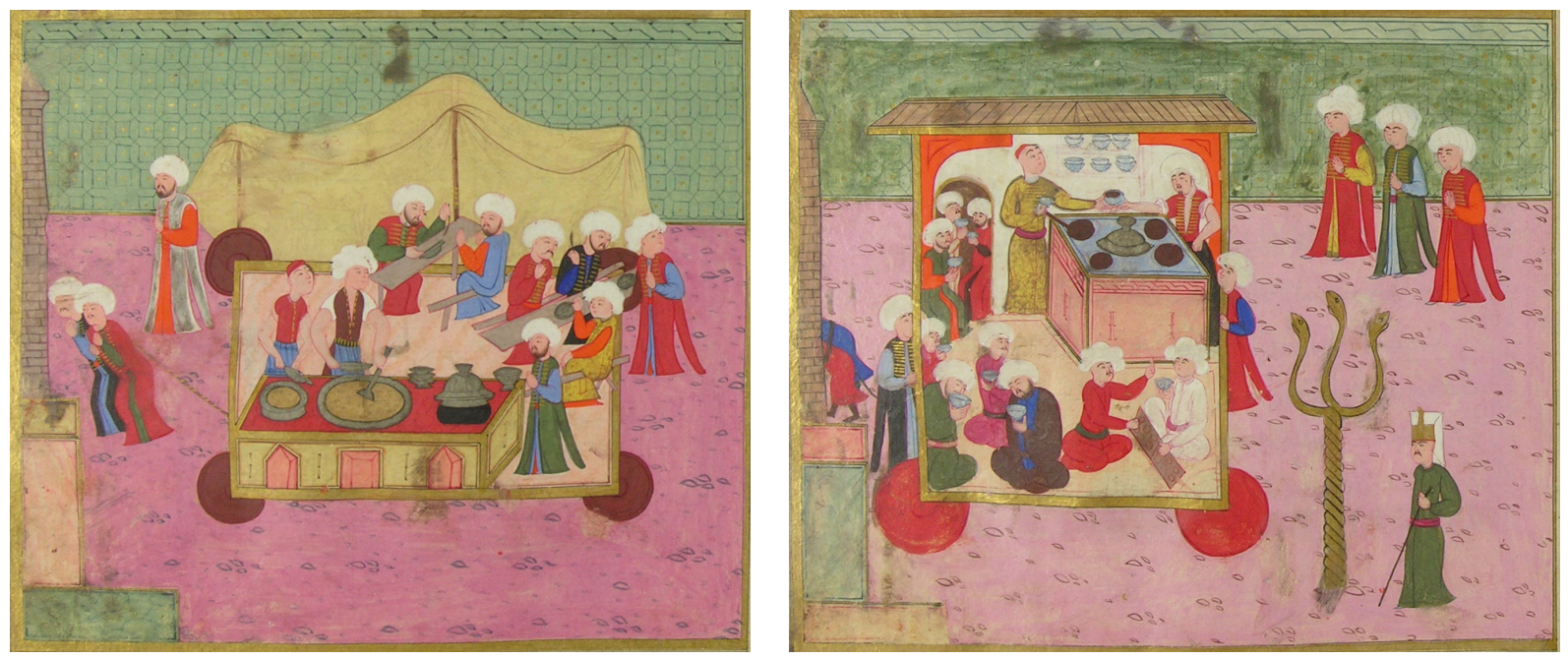

ve binlerle ifade edilen yoğun kalabalığı, diğer taraftan bu kalabalıklar içinde seçilen güzeller üzerinde durur. Kalabalığın her türden olaya gebe yoğunluğu metnin kuvvetli odaklarından biridir. Bununla bağlantılı diğer bir odak, kendilerine övgüler düzülen civanların-ve onların aracılığı ile çarşının, dükkânların, başka şehir mekânlarınıntemsili, bir bakıma Sûrnâme'nin başrol oyuncuları olan genç erkekleri bezeyen ve çevreleyen eşyanın görüntüsü, dokusu, hissidir. Metin meydandaki kalabalığı okura sürekli hatırlatsa da, Sûrnâme'yi resimleyen Nakkaş Osman ve ekibinin tutarlı tercihi daha az sayıda meslek sahibini, bunlar arasında da her cemaatin civanlarını-bazen çiftler halinde, bazen daha az sayıdaki yetişkin meslektaşlarıyla veya aşçı, kebapçı, berber dükkânlarının, kahvehanenin barındırdığı gruplar içerisinde-resmetmek; giysi ve süslerini, kullandıkları veya sergiledikleri eşyanın renklerini, malzemesinin dokusunu, bezemesinin niteliğini, maddi kıymetini ve estetik özelliklerini görselleştirmek olmuştur. ${ }^{61}$ Sahne benzeri fiktif mekânlar olsalar da Sûrnâme'nin dükkân modelleri yeri ve eşyayı önceleme, grupları ve bireyleri bulundukları yer, çevrelendikleri veya sattıkları eşya ile betimleme halini, dolayısı ile yerleşik olma halini, kitabın tanımlayıcı özelliklerinden biri haline getirir. Tekerlekler üzerindeki modeller, çarşıyı ve başka kamusal mekânları meydanla örtüştürür. Sûrnâme resimlerinin esnaf betimlemeleri, sosyal tiplerle mahbupları örtüştüren, yere ve eşyaya kuvvetle bağlı tasvirleri ile Sûrnâme metnini takip eder (şek. 11a ve 11b).

Bu metin on altıncı yüzyılda Osmanlı dünyasında dolaşıma giren şehrengizleri ve meslek, özellikle de zanaat ehline odaklı bir dizi başka eseri-İrani dünyada da, bazı örnekleri ile şahraşub türünü-şekillendiren, her bir esnaf ve meslek grubunu veya bu grubu temsil eden civanlardan birini, işini icra ettiğgi yere, ürettiği ve sattığı metaya, sunduğu hizmete, kullandığ aletlere-kimi zaman mizahi-göndermelerle tarif etme kalıplarına uyar. ${ }^{62}$ Farklı biçim ve türlere ait bir dizi eseri içeren, şehrengizlerden Zati'nin Letâyif ine, Safi'nin Hasb-ı Hâl'inden Letâif-i Esnaf mecmualarına uzanan bu geniş yelpazeyi şehirli öznelliklerin temayüz ettiği alanlardan biri olarak tanımlarsak, Sûrnâme resimlerini bu yelpazenin barındırdığı erotik ve toplumsal odakları görselleştirmeleri açısından okuyabiliriz. Kitabın resimlerinin çoğunluğunu oluşturan esnaf alayı tasvirlerinin, genç erkeklere yönelik bakışı, toplumsal katmanları ve özellikle zanaat ehlini tanımlamaya yönelik tasnifçi bir bakış ile örtüştüren temsil kalıplarının
Şekil 11a-11b: Sûrnâme'de aşçı dükkânı ve kahvehane. Nakkaş Osman ve atölyesi, İntizami, Sûrnâme, TSMK H 1344, 1588, 263a, 367a'dan detaylar.

61 Bu senelerin nakkaşhane ressamları Sûrnâme metninde tasvir edilen, yüzlerce kişilik alaylarla meydandan geçen meslek taifelerini ve geçenleri seyreden kalabalıkları resmetme hünerine sahiptiler; hanedan tarihlerini resimleyen, çift sayfaya yerleștirilmiş savaş ve kuşatma temsilleri, bu temsillerdeki kalabalık ve hareket halindeki ordular veya elçilik heyetlerinin saraya kabulünü konu edinen resimler bu yöndeki maharetlerine (ve Sûrnâme ressamlarının kalabalığı değil şahısları resmetmek üzere yaptıkları seçime) işaret eder. Örnekler için, Bağc1 et al., Osmanlt Resim Sanatt, 149, 152, 153, 175 .

62 Derin Terzioğlu Sûrnâme'de civanlara yönelen bakıșın Osmanlı edebiyat dünyasında özellikle on altınc1 yüzyıl boyunca yaygınlaşan șehrengiz türünü çağrıștırdığına dikkat çekiyor; Terzioğlu, "The Imperial Circumcision Festival," 95. Diğer yandan, șehrengizler isimleri ile anılan (dolayısı ile şairin önerisine göre kimlikleri belli olan) civanları konu ederken, Sûrnâme metni esnaf tipleri veya cemaatin anonim üyeleri üzerinde durur; ressamlar bu tipleri (veya kalıpları) resmeder. Nitekim Selim S. Kuru şehrengiz yazarlarının bu eserlerin konusu olan güzelleri isimleriyle, bireyler olarak anmalarının bu türün ayrıştırıcı bir özelliği olduğunu belirtiyor, bu bakımdan Sûrnâme anlatılarının șehrengizlerden ayrı düștüğünü söyleyebiliriz; bkz. Selim S. Kuru, "Naming the Beloved in Ottoman Turkish Gazel: The Case of İshak Çelebi (d. 1537/8)," Ghazal as World Literature II. From a Literary Genre to a Great Tradition: The Ottoman Gazel in Context, der. Angelika Neuwirth et al. (Würzburg: Ergon Verlag, 2006), 168-172. 
Osmanlı dünyasındaki ilk görsel ifadeleri olduklarını söyleyebiliriz. (Bu eserlerin tür, izlek, vurgu, bağlantılı oldukları coğrafyalar açılarından farklılıklarını teslim ediyorum. Bununla birlikte meslek ehli, zümreler ve bunların çoğunluğunu teşkil eden şehirliler üzerindeki odağın bu dönemde görünürlüğ̈̈ artan, birleştirici bir çerçeve oluşturduğunu ve bu çerçevenin görsel temsili de şekillendirdiğini öneriyorum. $)^{63}$

$\mathrm{Bu}$ çerçeve, resimlerin sergilediği eşya ve giysi çeşitliliğini okumanın yollarından birini sunar. İntizami'nin Sûrnâme'nin sonunda atıfta bulunduğu ve tercüman olduğunu iddia ettiği-İrani ve Rumi dünyalarda şehirliler üzerine odaklanan edebiyatın izleklerinden biri olan-her bir esnafa has meslek dili (veya jargonu), sergilenen eşya yelpazesinde görselleşir. ${ }^{64}$ Resimler kişiselleştirilmiş portrelerden çok sosyal tipleri betimlerken, kişileri çevreleyen üretim, değişim ve hediye alışverişi ağlarını cisimleştirir; Sûrnâme metninin ve resimlerinin kuvvetli odaklarından biri olan eşya, toplumsal kimlik ve failliklerin bir boyutu olarak anlam kazanır. ${ }^{65}$ Eşya üzerine odaklanan bakış, bu eşyanın, eşyayı üretenlerin, ticaretini yapanların ve kullananların şehrin ekosisteminde ve Osmanlı ülkesini aşan geniş coğrafyada birbirine bağlandığı, erken modern dönemde daha fazla görünürlük kazanan karmaşık ilişkiler ağına da atıfta bulunur. Şehirde ve çeperinde üretilen çeşit çeşit şeyler meydana taşınır; metin ve resimler eşyalar aracılığ 1 ile başka coğrafyalara atıfta bulunur: Tekerlekler üzerinde meydandan geçen kahvehanede, meclisin mîri bir civan fusûs-kâri abanoz sandalye üzerine oturur; Venedik frengisi basma kumaşlar üzerine rumi ve hatayi enva1 renk yapraklar işlenir; Acemi ve Şirvani başmaklar meydanda sergilenir; kumaş tacirleri cins cins Hint, Çin, Yemen atlas ve kemhaları, Kandahar ve Sagar imameleri, Mısır ve Berberi cameleri, Halep kumaşları sergiler; kimi Mısri kimi Hicazi yelpazeciler, rumi ve hatayi yapraklar nakş edip Çin ve Maçin'i, Irak ve Isfahan'ı dolanırlar (şek. 12a-12d). ${ }^{66}$ Sergilenen şeyler gibi sergilenen müzik de seyre dâhildir: Şenliğe katılanlar icra edilen müzik aracılı̆̆ıyla makamların işaret ettiği yerleri seyreder, mesela sazendeler "şive-kâr cüvânâna şehnâz makâmında İsfahan ve Irak'ı seyr" ettirirler. ${ }^{67}$

Sûrnâme tümüyle saraya özgü kitap üretme süreçlerinin ürünüdür; aynı zamanda ip cambazının sultana hitabında ifade bulduğu gibi, şenliği tasarlayanların, katılanların ve anlatıcılarının öznelliklerini, hegemonik bakışın ve sesin dışındaki bakışları ve sesleri de barındırır. Kamusal hayatın dönüşümlerini mekânsal, maddi ve görsel boyutları ile (de) okumak üzere bir fırsat sunar. ${ }^{68}$ Erken modern döneme özgü yeni kamusallıkların dinamik ve değişken, oluşum süreçlerini önceleyen bir tanımına ulaşmayı amaçlayan Paul Yachnin ve Brendan Wilson'a göre bu yüzyılların yeni kamusal varoluş, etkileşim ve ifade şekillerinin bir boyutu, başka başka "huruc etme," ortaya/meydana çıkma halleridir; yeni türden meydana çıkışlar yeni türden öznellikleri, toplumsal bağlantılar üzerine, eşya üzerine ve dünya üzerine yeni düşünme şekillerini yansıtır. ${ }^{69}$ Erken modern dönem şehirlerinde toplumsal ve kültürel yapıların oluşum süreçlerini önceleyen çalışmasında Derek Keene de bu dönem kentlerinde, zayıf toplumsal ağların ve kurumsallıkların mümkün kıldığı dinamizme, yeni fikirlere ve pratiklere açık olma haline, "zayıf ağların gücü"ne dikkat çeker. ${ }^{70}$ Sûrnâme'yi bu önerilerle birlikte, şehrin ve sarayın

63 Şehrengizler için, Agah Sırrı Levend, Türk Edebiyatında Şehr-engizler ve Şehr-engizlerde Istanbul (İstanbul: Fetih Derneği, 1958); Barış Karacasu, "Türk Edebiyatında Sehr-engîzler," Türkiye Arastırmaları Literatür Dergisi 5 (2007): 259-313; Kuru, "Naming the Beloved." Çarşı sakini mahbuplara yönelen şiir için, Walter Andrews ve Mehmet Kalpakl, The Age of Beloveds: Love the the Beloved in Early-Modern Ottoman and European Culture and Society (Durham: Duke University Press, 2005), 39-43, vs. İrani dünyada Şahraşub türü için, Sunil Sharma, "Generic Innovation on Sayfi Buhara'i’s Shahrashub Ghazals," Ghazal as World Literature 1I, 141-152. Meslek özelliklerini siralayan takvim türü, mizahi eserler ve Zâtînin bu türdeki eseri için bkz. Mehmed Cavusoğlu, "Zâtînin Letâyifi - Il," Türk Dili ve Edebiyatı Dergisi 22 (1977): 143-161. Zâtî'nin gazel ve mesnevilerinde yerellik, esnaf ve tüccar odağı için, Sooyong Kim, The Last of an Age: The Making and Unmaking of a Sixteenth-century Ottoman Poet (Londra: Routledge, 2018). Ayrıca bkz. Hasbihâl-i Sâfî: İnceleme, Metin Tipkıbasım, haz. Hanife Dilek Batislam (İstanbul: Kitabevi, 2003); M. Kemal Özergin, "Letâif-i Esnaf," Türk Folklor Araştırmaları Dergisi 209 (Aralık 1966): 4276-4278; "Letâif-i Esnâf'dan, l: Etmekci," Türk Folklor Araştırmaları Dergisi (Eylül 1970): 5742-5744. Sûrnâme türü eserlerde esnaf üzerine Arslan, Türk Edebiyatında Manzum Sûrnâmeler, 218-232.

64 Bu eserlerde mesleklere has deyim ve kavramlar için, Çavuşoğlu, "Zâtî̀nin Letâyifi - II, 145-146; Özergin, "Letâif-i Esnâf'dan." Mehmet Arslan Sûrnâme'nin içerdiği, farklı zanaatlara ve zanaatkârlara mahsus kelimelerin ve üslup özelliklerinin zenginliğine ve kıymetine dikkat çekiyor; Arslan, Intizâmi, 66-77. Zanaatlara has diller veya zanaat jargonları olgusu, bu dönemin İrani edebiyatının da özelliklerinden biridir. Mehdi Keyvani, kelime dağarcığı, gramer, ses ve vurgu açılarından ayrıșan meslek jargonlarının (zabân) özellikle şahrașub türü eserlerde takip edilebildiğini belirtiyor, bkz. Keyvani, "Artisans and Guild Life," 237-238.

65 Şeylerin failliği üzerine, Alfred Gell, Art and Agency: An Anthropological Theory (Oxford: Clarendon Press, 1998), 17-21.

66 İntizami, Sûrnâme, 86b, 163b-164a, 191a, 223a-224b, 243a-244b, 368a; Arslan, İtizâmi, 263, 319-20, 334, 436.

67 İntizami, Sûrnâme, 443a; Arslan, İntizâmi, 443.

68 Habermasyen çerçeveyi bașlangıç noktalarından biri olarak alan, kamusallığın sürece dayalı, dinamik yorumlarına ulaşmayı amaçlayan çalışmalar, sûr ve Sûrnâme'yi oluşmakta olan kamusallıklar açısından yorumlamak için bir yol sunabilir; Bronwen Wilson ve Paul Yachnin, "Introduction," Making Publics, 2-19; Marlene Eberhart, Amy Scott ve Paul Yachnin, "Introduction," Forms of Association, 2-16.

69 Wilson ve Yachnin, "Introduction," 2-3.

70 Derek Keene, "Cities and Cultural Exchange," Cities and Cultural Exchange in Europe 1400-1700, Cultural Exchange in Early Modern Europe c. 2, der. Donatella Calabi ve Stephen Turk Christensen (Cambridge: Cambridge University Press, 2007), 20-23. 

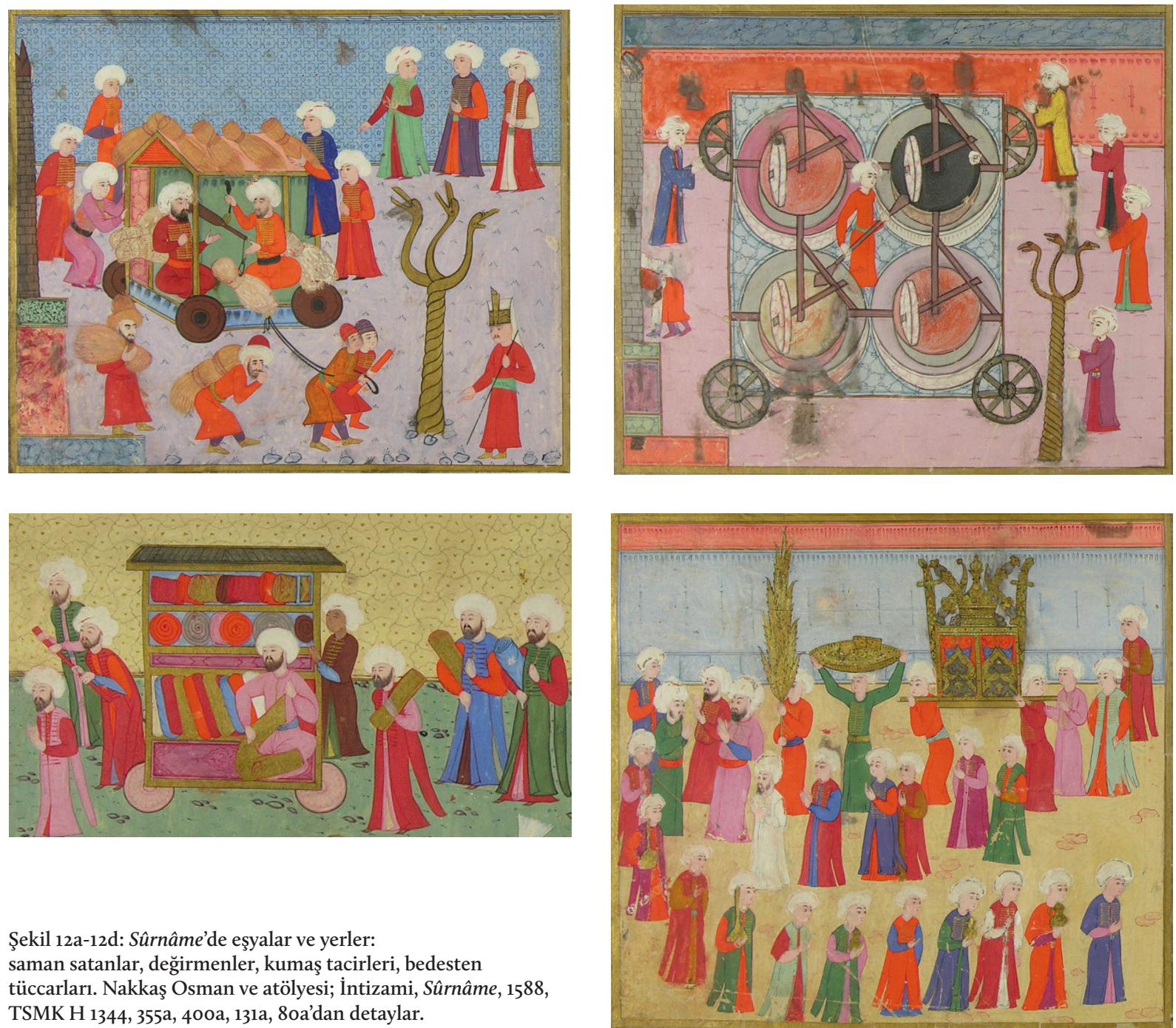

Şekil 12a-12d: Sûrnâme'de eşyalar ve yerler: saman satanlar, değirmenler, kumaş tacirleri, bedesten tüccarları. Nakkaş Osman ve atölyesi; İntizami, Sûrnâme, 1588, TSMK H 1344, 355a, 400a, 131a, 8oa'dan detaylar.

yeni türden meydana çıkışlarının temsili olarak okuyabiliriz. Sûr ve Sûrnâme bir yandan sultanın ve sarayın yeni kamusal imgesinin oluşmasının, şehri ve şehirlileri de bu imgenin anlam dünyasına dâhil etmesinin aracılarıdır; ${ }^{71}$ bir yandan da oluşmakta olan toplumsal ağların, yeni türden öznelliklerin ve sosyalleşmelerin meydana çıkmasına aracıllk ederler. Esnaf taifelerinin oluşum süreçleri zarfında barındırdıkları toplumsallığın ve temsil pratiklerinin yeri ve tanığıdırlar. ${ }^{72}$

Esnaf veya lonca alayları olarak okumaya alışık olduğumuz Sûrnâme tasvirlerinin bu açıdan çarpıcı bir özelliği, şehirli esnaf, bölgelerarası ticaretle uğraşan zengin tüccar, saraya bağlı hüner ehli ve askeri zümreye bağlı çeşitli hizmet ve zanaat grupları, âlimler, suhteler ve derviş grupları arasında, Osmanlı siyasasını şekillendiren geniş toplumsal kategorilere göre bir ayrım yapmamalarıdır. Âli'ye göre katılanların tümü ehl-i hıref ve kâsibîn zümreleridir.73 İntizami Sûrnâme'nin 1584 tarihli kopyasında şenliğe katılanlardan fırka ve zümreler olarak bahseder. Resimli nüshada meslek ehlini ve göstericileri yalnızca meslek adları ile zikreder;

71 Sûrnâme bu bakımdan şehname türündeki eserlerle bağlantılı olarak düşünülebilir. Dönemin şehname türü eserlerinin sultanın sarayda ve kamusal alanlardaki imgesi ile bağlantıları üzerine, Woodhead, "Murad 111 and the Historians," Fetvacı, Picturing History at the Ottoman Court.

72 Esnaf taifeleri üzerine, Suraiya Faroqhi, Artisans of Empire: Crafts and Craftspeople under the Ottomans (Londra: I.B. Tauris, 2009), 21-44; Eunjeong Yi, Guild Dynamics in Seventeenth-century Istanbul, Fluidity and Leverage (Leiden: Brill, 2004).

73 Mustafa Âli, Câmi'u'l-buhûr, 414. 
saray teşkilatına bağlı meslek ehlini ayrıca belirtmez. Bir sonraki yüzyılın anlatıcıları bu muğlaklıktan bir derece uzaklaşacak, Evliya Çelebi 1638'de İstanbul'da düzenlenen alaya dair anlatısında padişaha mahsus kârhaneleri, saray ve askeri teşkilat dâhilindeki esnafı miri veya sultani olarak ayırt edecek; IV. Mehmed'in şehzadelerinin 1675'te Edirne'de düzenlenen sünnet şenliği için yazdığı sûrnâmede Nabi ehl-i hıref ve ehl-i bazar, erbab-1 hıref, güruh-1 bazar tanımlamalarıyla saray ve şehir zanaatkârlarını ayrıştıracaktır. ${ }^{74}$

Kitap üretimi, okuryazarlık ve-bu yazı açısından-resimli kitap üretimi dinamiklerinin dönüştüğü, saray ve şehir arasında değişen ilişkilerin yeni kamusallıkların görsel temsiline aracı olduğu bu yıllarda, şehirliler başka kitaplarda, başka bağlamlarda da görünür oldular. Nil kıyılarında ve üzerindeki kayıklarda keyifle kahvelerini yudumlayarak, bir kıyamet anlatısını resimlendirdiler; Zati Letâyifinin, Hasbıhâl-i Sâfi'nin ve daha sonraki anonim metinlerin meslek kategorilerini çağrıştıran bir tabloda padişahtan süpürgeciye çeşitli meslek erbabının kutucuklar içinde mini portreleri, yıldızların ve burçların mesleklerle eşleşmesine aracılık etti. ${ }^{75}$ Sehirli tiplemeleri ve șehirde bulunma halleri, Osmanlı sarayında resimli tarih kitaplarına ilginin sönmesinin ardından, sarayda ve şehirde üretilen albümlerin konusu oldu; şehir oğlanlarından meslek ehline, sokaktaki kadınlara ve kadınların sokakta bulunma hallerine dair resimler albüm sayfalarında boy göstermeye devam ettiler. ${ }^{76}$

Kentsel mekânlar ve sokak odaklı anlatı resimlerini konumlandırmaya ve anlamaya çalışırken, İrani ve Rumi dünyalar arasındaki bağlantılar ve etkileşim ağları da görünürlük kazanır. 1580 ve 159o'larda Şiraz'da, bir kısmı Osmanlı okurları için üretilen edebi konulu yazmaları resimleyen şehir ve şehirli temaları bu bakımdan dikkat çeker. İrani ve Rumi görsel kültürlerinde sokağın, çarşının ve meydanın aynı dönemde resmedilir olmasının arka planında kentsel dinamiklerdeki koşutluklarla birlikte, büyük sayılarda Osmanlı ülkesine getirilen Şiraz yazmalarında görünürlük kazanan şehir ve sokak temalarının tam da bu yıllarda Osmanlı ressamlarının ve hamilerinin ilgisini çekmiş olması da bulunabilir. ${ }^{77}$ Bazıları Sûrnâme'nin sayfa düzeni ile karşılaştırılabilecek-sokak, çarşı ve meydan betimlerinde, resim alanının birbiri üzerine yerleştirilmiş yatay bölünmelerle ayrıldığı-bu imgelerin ortak özelliği mekânlarının çarşı, dükkân, sokak, meydan olması, pek çoğunun yeri sokak veya dükkân olan anlatılarla birlikte zanaatları ve zanaatkârları, dokuları, renkleri, bezemelerinin ince detayları ile temsil edilen eşyanın maddeselliğini konu edinmeleridir. Lale Uluç 1550'lere kadar hiç resimlendirilmemiş olan Mecâlisül'Uşşak'ın resimli kopyalarının üretilmesinin yeni bir ikonografyayı olası kıldığına dikkat çeker; şehir temalı resimler özellikle 1580 'ler ve sonrasına tarihlenen Mecâlis yazmalarında ve bu senelerin başka eserlerinde görünürlük kazanır (şek. 13). ${ }^{78}$ 1580'lerin Mecâlisü'l- 'Uşşâk resimlerinden birçoğu şeyhlerin, dervişlerin, âlimlerin mahbuplarla, en çok da çarşıda, karşılaşmalarını temsil ederken, uzun ve kayda değer görsellik tarihlerine sahip Firdevsi Şehname'sinin veya Cami'nin Heft Peyker'inin ve Nizami Hamse'sinin bu y1llarda üretilen yazmaları da, şehre ve şehirlilere odaklı yeni görselliğin izlerini kuvvetle taşırlar. İrani dünyanın savaşlarda, taht odalarında veya otağlarında, rakipleri ile karşılaşmalarda, meclislerde resmedilegelmiş kahramanları bu yeni resimlerde giderek daha sıklıkla şehirlerin kamusal mekânlarında tasvir edilirler: Behram Gur çini ve kaftan dükkânlarının önünde, bu dükkanların sakinlerinin bakışları arasında şehre girer; Feridun Zahhak'ı bir cami ve evlerle (veya saraylarla?) çevrelenmiş bir meydanda alt eder; İskender, Rayy şehrine girerken

74 Nâbî Sûrnâmesi, haz. Arslan, Türk Edebiyatında Manzum Sûrnâmeler, 627-684; Evliya Çelebi, Evliya Çelebi Seyahatnamesi, 1. Kitap, haz. Robert Dankoff, Seyit Ali Kahraman ve Yücel Dağlı (İstanbul: Yapı Kredi, 2006), 240-339.

75 Tercüme-i Miftâh-ı Cifrül'-Câmi', İstanbul Üniversitesi Kütüphanesi T 6624, 126a; Su'ûdi, Matâli'ü's-sa'âde ve yenâbi'ü's-siyâde, Paris, Bibliothque nationale de France, Turc 242, 32b-33a. Resimler için: Kafescioglu, "Görsel Sanatlar," 645, ve Bağc1 ve diğerleri, Osmanl Resim Sanatı, 191. Su'ûdi'nin astrolojik eserinde mesleklerle yıldızları eşleştiren tablo ile, takvim türündeki, meslekleri yıldızların seyriyle ilişkilendiren eserlerden esin taşıyan Letayif in kavramsal benzerliği dikkat çekicidir. Takvimler ve Letayif için, Çavuşoğlu, "Zâtînin Letâyifi."

76 Tülün Değirmenci, "An illustrated mecmua: the commoner's voice and the iconography of the court in seventeenth-century Ottoman painting," Ars Orientalis 41 (2011): 186-218; “Kahve Bahane Kahvehane Şahane: Bir Osmanlı Kahvehanesinin 'Portre'si,” Bir Taşım Keyif: Türk Kahvesinin 500 Ylllk Öyküsü, der. Ersu Pekin (Ankara: Kültür ve Turizm Bakanlığ1, 2015), 119-137; "Osmanlı Tasvir Sanatında Görselin "Okunması": İmgenin Ardındaki Hikâyeler (Șehir Oğlanları ve İstanbul'un Meşhur Kadınları)," Osmanlı Araștırmaları 45 (2015): 25-55; Emine Fetvac1, The Album of the World Emperor: Cross Cultural Collecting and the Art of Album Making in Seventeenth-century Istanbul (Princeton: Princeton University Press, 2019); "Love in the Album of Ahmed I" Journal of Turkish Studies 34 (2010): 37-52; "The Gaze in the Album of Ahmed l," Muqarnas 32 (2015): 135-154.

77 On altıncı yüzyıl Şiraz resimli yazmaları ve Osmanlı okurları için, Lale Uluç, Türkmen Valiler, Şirazlı Ustalar, Osmanlı Okurlar: 16. Yüzyll Șiraz Elyazmaları (ìstanbul: İş Bankası, 2006), 469-505.

78 Lale Uluç'un Şiraz'da üretilen Mecâlisü'l-'Uşsâk yazmaları üzerine gözlemlerinde aktardığı gibi, bu metnin resimli kopyaları sokak hayatına ve şehirliler üzerine 1580'lere kadar görülmeyen bir vurgu yapar; Uluç, Türkmen Valiler, 183-223, 414-422. 


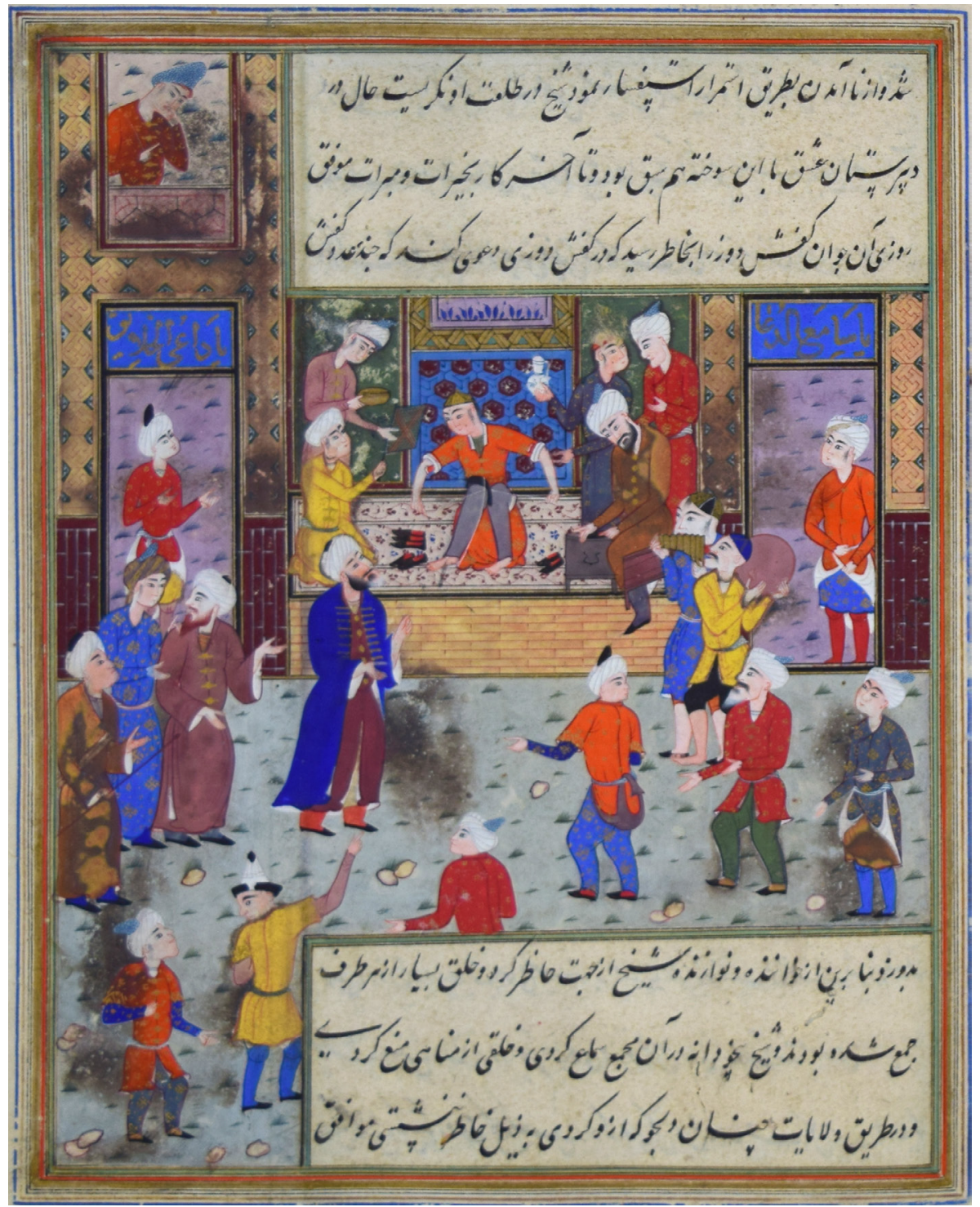

Şekil 13: "Şeyh Azri bir nevcivan kefşduza mübtela olduğu meclisdir." Gazurgahi, Mecâlis al-Uşşâk, 1580 civarı, TSMK H 829 , $192 \mathrm{a}$.

resmedilir (şek. 14) $\cdot{ }^{79}$ Kadim kahramanların yeni sahnelerde yer alması ve yeni konuların, özellikle sokağın ve çarşının görsel temsil dünyasına girmesinde büyüyen şehir nüfuslarının, yoğunlaşan ticaret hayatının, kamusal mekânların ve kullanıcılarının görünürlügünün artmasının rolü olmalıdır. Ne tür toplumsal dönüşümlerin ve bunlarla bağlantılı kitap üretim ve okuma pratiklerinin İskender'i ve Behram Gur'u atlarını çarşı sokaklarında, dükkânların ve dükkâncıların önünde sürmeye yönelttiği ise, üzerinde daha fazla durmaya değer bir konudur. ${ }^{80}$ 
Şekil 14: Behram Gur'un Hakan'in kızı ile İran'a dönmesi. Firdevsi, Şehnâme, 1585 , TSMK R 1548, $460 b$.

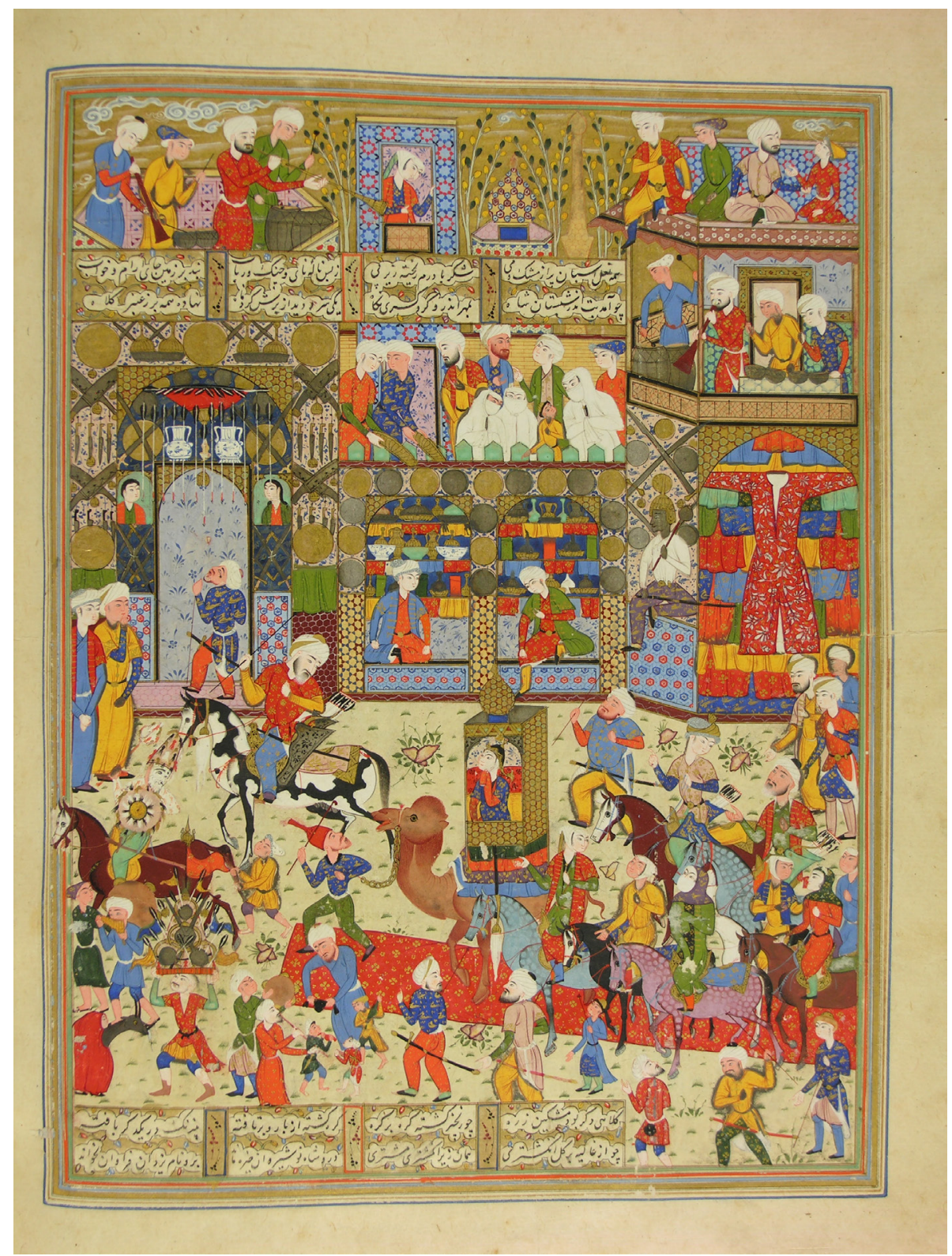

\section{"Böyle izdihâm-1 nüfûs-1 insânî ve hayvânî bir târîhde görülmüş̧ ve işidilmiş degildi"»1}

Zamana uyup sokağı ve meydanı mekân tutan İskender ve Behram Gur'dan zamanın kahramanlarına dönecek olursam: Bu dönemin tarihyazımında İstanbul sokaklarına ve Atmeydanı'na dair anlatıların izini sürmek yeni imgelerin, siyasi konjonktür ile yakından bağlantılı bir başka boyutu ile karşılaşmamızı sağlar. Sûrnâme'nin tamamlanıp harem ağası Zeyrek Ağa ve Mehmed Ağa aracılığı ile IIl. Murad'a sunulması 1588 veya takip eden yilda gerçekleşmiş olmalıdır. Yeniden yazılmış, Nakkaş Osman ve atölyesinin ressamlarınca resimlenmiş Sûrnâme'nin saraya sunulmasi, 1589 senesinde, sipahi ulufelerinin eksik akçe ile ödenmesi sonucu çıan ayaklanmada öldürülen beylerbeyi Mehmed Paşa'ya atıfla "Beylerbeyi Vakası" olarak anılan olaya muhtemelen yakın düşer. Beylerbeyinin kesik başı ayaklanan sipahilerin tekmeleriyle saray avlusundan Atmeydanı'na kadar yuvarlanmış, sarayda başlayan, şehir sokaklarında ve meydanda sergilenen bu dehşetli gösteri dönemin tarih anlatılarında 
34 yer bulmuştur. ${ }^{82} 1582$ şenliğinin de, yeniçeriler ve sipahiler arasındaki çatışma ile sonlandığını, ölen sipahilerden birinin yeniçeriler tarafından Atmeydanı'na, İntizami'ye göre, "'atebe-i 'âlîyyeye mukâbil” bir yere, Sultan Murad'ın görmesine imkân verecek şekilde terk edildiğini, Sûrnâme'nin son resimlerinden birinin meydanda padişahın seyri için bırakılmış açık bir tabutu gösterdiğini hatırlayalım. ${ }^{83} \mathrm{Bu}$ iki olay, şehirde çatışma ve ayaklanmalarla dolu bir buçuk yüzyıllık dönemin başlangıcına işaret eder; takip eden yıllarda yapısal ve kurumsal dönüşümler karşısında oluşan tepkiler başkentin kamusal mekânlarını giderek daha kalabalık, çatışmalara gebe müzakere mekânları haline getirecektir. ${ }^{84}$ Siyasi yapının ve yeniden dağıtım mekanizmalarının dönüştügü̈, bozulan ekonomik dengelerin farklı sosyal grupların yaşam düzeylerini doğrudan etkilediği bu dönem farklı boyutları ile Osmanlı tarihçilerinin son senelerde derinlemesine çalıştıkları bir konu. Diğer yandan, zanaatkâr taifelerinin giderek içsel unsurları haline gelen yeniçerilerin, tacirler ve zanaatkârların, ulemanın ve suhtelerin de aktörleri arasında bulunduğu toplumsal ağlar ve hareketlilik mekânsal ve görsel boyutları açısından daha yakın zamanlarda dikkat çekmeye başladı. ${ }^{85}$

Selaniki'den birkaç alıntı ile 1580'ler ve 159o'larda İstanbul'un sokaklarını sık sık dolduran gergin kalabalığı izleyebiliriz: Halkın "bî-edeb" olduğundan, "bu vâsıtayla divân-1 âlîye girip küstahlığa sebeb" olduklarından; "ahlâk-1 halk yaramaz olduğundan"; "izdiham-1 halk, seyirci ve erâzil-i nâs ve erbaş u kallâş cem olup artmakda" olduğundan bahseder. Halkın "gulgule" ve "dagdaga"sının dışarı çıkmaya mani olduğunu; "şehr-i kostantiniyyede her-giz böyle izdihâm-1 nüfûs-1 insâni ve hayvâni" görülmediğini ve işitilmediğini yazar; "halk bu vechile bir yerde gelüp cem 'iyyet eylemek lâyı u münâsib degildür," der. ${ }^{86}$ Dönem anlatıları meydanda ve -dönem tarihçilerinin Şahrah olarak bahsettikleri-Divanyolu'nda, saray kapısında, yeniçeri odalarının bitişiğindeki Etmeydanı'nda, başka saray kapılarında, kamusal mekânın performatif inşasına tekrar tekrar şahitlik ederler-daha doğrusu inşalarına demek gerekir, çünkü her bir vaka, bu gerilimli ve çatışmalı dönemin her bir noktası, geniş İstanbullular yelpazesinin farklı aktörlerini, mekânı sahiplenmek, taleplerini ve iddialarını şehir hayatının merkezi mekânlarında ve bu mekânlar aracılığıyla ortaya koymak üzere meydana çıkarır; her bir meydana çıkış farklı grupların çelişen ve çatışan yer kurgularına ve inşalarına aracı olur. 1580 'lerin sonundan on yedinci yüzyıla doğru bakacak olursak, bir yanda Atmeydanı'nda, saray ve cami avlularında toplantılar ve müzakereler; isyanciların Atmeydanı'nda ve Etmeydanı'nda kurdukları çadırlar; Atmeydanı'nda ağaçlardan sallandırılan, Yılanlı Sütun'a asılan ölüler; sokak çatışmaları, linç vakaları; diğer yanda, sünnet düğününe şahitlik ettiğimiz Ill. Mehmed'i (1595-1603) ve haleflerini, şehirde sürekli ve düzenli olarak görünür kılan cami ve Eyüp ziyaretleri, bu ziyaretler sırasında gösterim boyutu herhalde önemli olan "ayak divanları," hem idari seçkinlerin hem de şehirlilerin sokağa ve meydana çımanın, siyasi talep ve iddiaları şehir mekânlarında-ve bu mekânlar aracıllğııla-ifade etmenin yolları üzerinde düşünmekte ve hareket etmekte olduğuna işaret eder.

Mustafa Âli'ye göre, Beylerbeyi Vakası'nın ardından Sultan Murad kullarının artık onun yüzünü göremeyeceklerini, saltanatın kokusunu (dahi?) alamayacaklarını söyler; padişahın kapısı kullarına duvar olmuştur. ${ }^{87}$ Birkaç sene sonra, IIl. Mehmed iktidarının ilk yılında, bölük halkının Haseki Hamamı önünde sadrazam Ferhad Paşa’nın önünü kesmeleri, Bab-1 Humayun dışında toplanmaları, saraya giriş çıkışları engellemeleri üzerine ulufeler At Meydanı (ibrahim Paşa) Sarayı'na iletilip orada dağıtılır; ${ }^{88}$ Topkapı'dan bu saraya geçiş, meydanın şehirdeki çatışmalı ortamın merkezine yerleşmesi yönünde yeni bir adımdır. Aynı senelerde dönem tarihlerinde yer bulan başka bir vaka, Safiye Sultan'ın kirası (hizmetkâr)

82 Âli, Künhü'l-Ahbâr, 548b-549a; Hasan Bey-zâde Ahmed Paşa, Hasan Bey-zâde Tarîhi, ed. Ş. N. Aykut, Ankara, Türk Tarih Kurumu, $347-352$. 83 İntizami, Sûrnâme, 423a-424b, resim, 423b-424a; Arslan, Intizâmi, 481-483. Bu olay için, Terzioğlu, "The Imperial Circumcision Festival," 88. 84 Kafadar, "Janissaries and Other Riffraff"; Gülay Yllmaz, "Blurred Boundaries between Soldiers and Civilians: Artisan Janissaries in Seventeenth-Century Istanbul," Bread from the Lion's Mouth: Artisans Struggling for a Living in Ottoman Cities, der. Suraiya Faroqhi (Ohio: Ohio University Press, 2009); Eunjeong Yi, "Artisans' Networks and Revolt in Late Seventeenth-Century Istanbul: An Examination of the Istanbul Artisans' Rebellion of 1688," Popular Protest and Political Participation in the Ottoman Empire. Studies in Honor of Suraiya Faroqhi, der. Eleni Gara, M. Erdem Kabaday1, Christoph K. Neumann (İstanbul: Bilgi University Press, 2011), 105-124; Gülay Y1lmaz, "The Economic and Social Roles of Janissaries in a Seventeenth-Century Ottoman City: The Case of Istanbul," (doktora tezi, McGill University, 2011). 85 Gülay Yılmaz on yedinci yüzyıl lstanbul'unda yeniçeri varlığının, ayaklanmaların ve siyasi hareketliliğin mekânsal boyutlarına dikkat çekiyor; Y1lmaz, "The Economic and Social Roles of Janissaries," 122-134, 155-174. Ayrica bkz. Tülay Artan, "Forms and Forums of Expression: Istanbul and Beyond, 1600-180o," The Ottoman World, der. Christine Woodhead (New York: Routledge, 2012), 378-406. 86 Selaniki, Târîh, 417, 421, 431, 468-73, 525.

87 "Görmez anlar beni șimden giru nâ-mahremdür / Çün olur dîde-i nâ-mahreme dîdâr harâm / Bağbân-1 felek ol kapuyı divar itdi / Saltanat bûyını anlar idemez istişmâm”; Mustafa Âli, Künhüll-Ahbâr, $550 a$.

88 Selaniki, Târîh, 468-73. 
Esperanza Malki'nin, yine sarayda başlayan, mahallede ve veziriazam sarayında devam eden, kiranın cesedinin Atmeydanı'nda bir ağaca asılmasıyla sonlanan hikâyesi de meydanın şehrin olaylar haritasındaki merkezi yerine-ve yine, adaletin sergileneceği yer olarak anlamınaişareteder. ${ }^{89}$

Hükümdarlı̆̆ının son senelerini Topkapı Sarayı'nın dışına pek çıkmadan geçiren Ill. Murad'ın ölümünün hemen ardından başlatılan yoğun törenler silsilesi sarayı ve yeni hükümdarı şehrin kamusal alanlarında görünür kıldı. III. Mehmed "âdet-i kadîm" uyarınca sultan cami ve türbelerine ve Eyüp'e ziyaretler gerçekleştirdi. Bu etraflı törenler ve törenlerin etraflı anlatıları Sultan Murad'ın hükümdarlığının son senelerinde saray kapısından dışarıya adım atmamış olmasının oluşturduğu olumsuz izlenimi değiştirmeyi ve bir yandan da şehirdeki hareketliliğe bir cevap oluşturmayı amaçlamış olmalı. Yine Selaniki'yi takip edecek olursak,

Devlete göre âsitâne olur

Her kuş içün bir âşiyâne olur

Sanmanuz halk olur zemâne göre

Belki halka göre zemâne olur ${ }^{\circ}$

III. Mehmed, III. Murad'ın kırkı çıkmadan Cuma namazlarını önce Ayasofya'da, sonra Süleymaniye'de, ardından Bayezid Camii'nde kılar, aynı ay içinde türbeler ziyaretine de çıkar. (Eyüp'ten babasının Ayasofya'daki-henüz türbe inşaatı başlamamış-mezarına kadar tüm sultan türbelerini ziyareti sonrasında, ikindi ezanı okunurken yine saraydadır: Hiçbir türbede pek uzun zaman geçirmemiştir. ${ }^{91}$ ) Saltanatının ilk haftalarında planlanan bu yoğun ziyaret ve tören programının bir parçası da Selaniki'nin Murad döneminde unutulup şimdi tekrar canlandırıldığını söylediği, "ayak dîvânı eylemek üslûbu üzre türbeler ziyâreti”dir. Kanun-1 kadim üzre, vüzerâ-i 'izam gidişte ve gelişte rütbelerine göre sultana yaklaşıp "umûr-1 mülk ü millet ahvâlin" üzerine söyleşirler.$^{92}$ Bu kadim kanunun ne kadar gerilere uzandığını bilmiyoruz, fakat mülk ve millet umuru üzerine söyleşilerin, Selaniki'nin tam bu senelerde, başka anayollar için de kullanılan Şahrah ismi ile birlikte Divanyolu olarak da adlandırmaya başladığı güzergah üzerinde yapılması, ayak divanının gösterim boyutuna dikkat çeker. ${ }^{93} \mathrm{III}$. Mehmed, Vefa Türbesi'ni, Lala Mehmed Paşa kabrini ziyaret eder, bu ziyaretler sırasında Kur'an okutur; Süleymaniye'de Cuma namazından sonra, yine kanun üzere, vüzera ile Zigetvar seferi üzerine sohbet eder.

Erkan-1 devlet ile yapılan, Selaniki'nin daha önce benzeri görülmemiş olarak tanımladığı Cuma alayları ile birlikte, tarihte görülmüş ve işitilmiş olmayan "izdihâm-ı nüfûs-ı insâni ve hayvâni," meydanda ve sokakta olmanın yeni hallerinin müzakere edilmekte olduğuna işaret eder. Benzeri görülmemiş kalabalıkların şehir mekânlarını, benzeri görülmemiş ayrıntı ve şaşaada törenlerle paylaşmaya çalıştığı bu senelerde, saltanatın sokaktaki varlığı-ve kalabalıkların ehlileştirilmiş imgesi-saray atölyelerinin ressamları tarafından ilk defa resimlenir. Elçilik heyetleriyle İstanbul'da bulunan, veya hamileri için Osmanlı başkentini tasvir eden Avrupalı ressamlar, on altıncı yüzyılın ortalarından itibaren saltanat alaylarını hiyerarşik düzenlerine, maddi zenginliklerine dair detaylarla tasvir etmişlerdi; saray sanatçılarının bu türden alayları konu edinen resimleri ilk defa bu senelerde tarih kitaplarına eklendi (şek. 15). III. Mehmed'in Egri seferinden zaferle dönüşünü tasvir eden resimde sultan ve maiyeti Divanyolu’nda, klymetli kumaşlardan oluşan ve onları kalabalık seyirci topluluğundan ayıran bir koridor içerisinde ilerler; ressam bu koreografinin seçilmiş izleyicisi olan Safevi elçi heyetini de dikkatle betimler. ${ }^{94}$ Egri zaferinin ve Safeviler'e yönelik Kütükoğlu "ayak divanı" teriminin acil durumlarda saray dışında toplanan divanlar için on yedinci yüzyıl sonlarına kadar kullanıldığın belirtiyor, ancak Selaniki’nin kullanımı ayak divanının burada değindiğim anlamını da ortaya koyuyor; Mübahat Kütükoğlu, "Ayak divanı," Türkiye Diyanet İşleri Vakfı İslam Ansiklopedisi, c. 4 (İstanbul: Türkiye Diyanet İşleri Vakfi, 1991), 192-193.

94 Talikizade, Şehnâme-i Mehmed Hân, TSMK H 1609, 68b-69a. Talikizade ve şahnamesi için, Christine Woodhead, "Ottoman Historiography on the Hungarian Campaigns: 1596 Eger Fethnamesi," VII. CIEPO Sempozyumu (Ankara: Türk Tarih Kurumu, 1994), 469477. Yazma ve resimleri için, Zeren Akalay (Tanınd1), "Nakkaş Hasan Paşa," Sanat 6 (1977): 114-25; Bağcı et al., Osmanl Resim Sanatı, 177-183; 


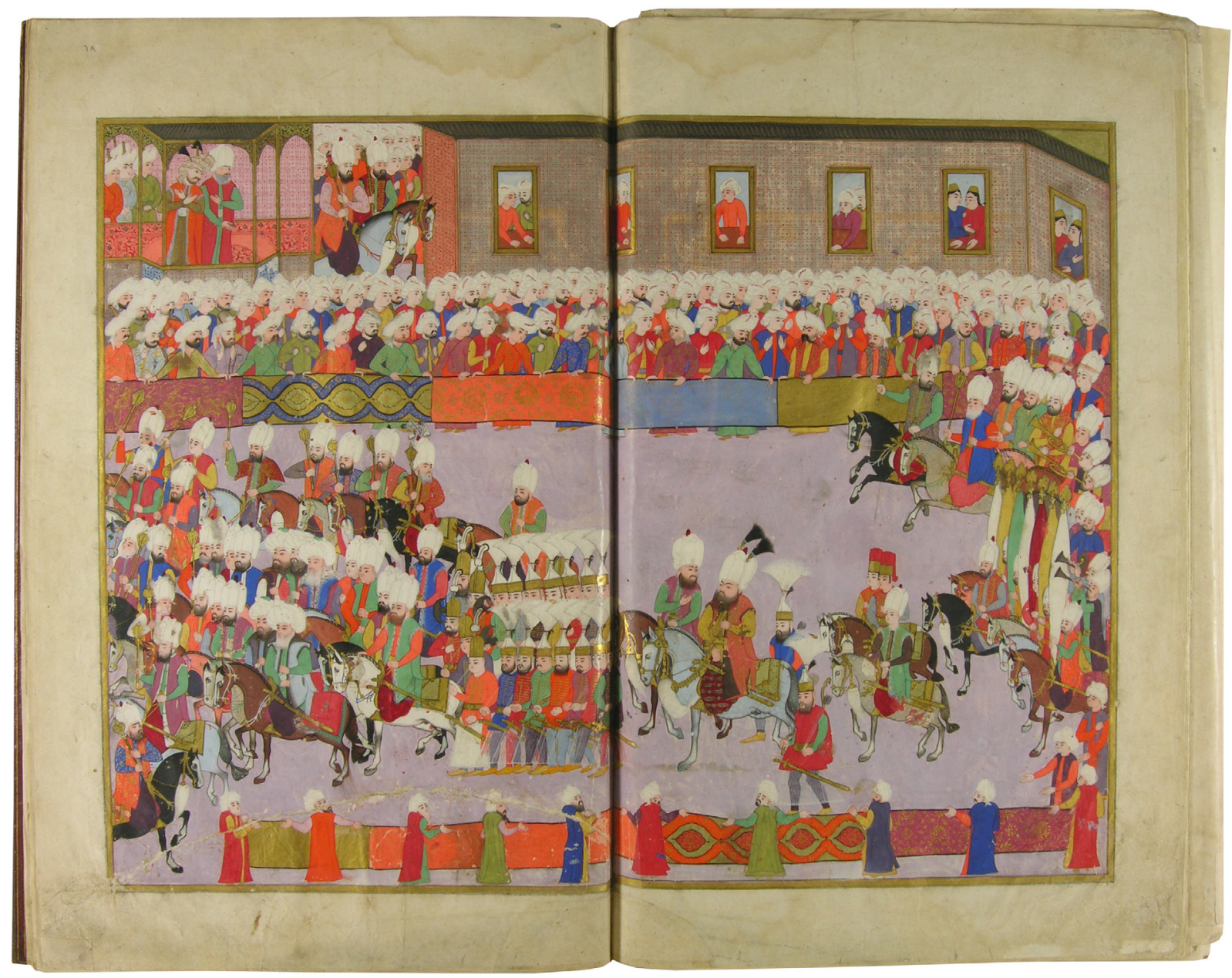

propagandanın yanı sıra bu, III. Mehmed'in saltanatının ilk günlerinden itibaren dikkatle kurgulanmış görünürlüğünün, Divanyolu'nun bu senelerde sık sık şahitlik ettiği anlaşılan alayların ve ayak divanlarının da resmidir. Şahnâme'nin yazarı Talikizade alayın şaşaası üzerine odaklanırken, Selaniki şahrahın iki yanında dizilip seyre duran, bin zirâdan fazla seraser, diba, atlas ve kemhalar uzatan bedesten ehlini ve çeşit çeşit kıymetli kumaşlarını sergileyen Yahûd, Nasâra ve Ermeniyye taifesini, evkaf mütevellileri ile imam, hatip ve hafızları, kasapları ve sair dükkândarları, bu arada ellerinde Acem ve Frengi kumaşlarla seyre katılan Safavi heyetini uzun uzun anlatır. ${ }^{95}$

Saray ressamlarının ve yazılarını resimledikleri tarihçilerin 1580'ler ve sonrasında şehrin kamusal mekânları üzerinde dikkatle durmasını, sokağın ve meydanın Osmanlı resim geleneğinde ilk defa resmedilmelerini İstanbul'un bu senelerde giderek kalabalıklaşan, giderek gerilen sokaklarını ve meydanlarını göz önüne alarak da yorumlayabiliriz. Bu kitaplar metnin ve resmin farklı işleyişleri, işlevleri, imkânları ve belki resmin tehlikeleri üzerine sorular sormak için de bize bir firsat sunar..$^{96}$ Şehri ve sarayı sarsan Beylerbeyi Vakası’nın, on yil kadar
Şekil 15: III. Mehmed Egri seferi dönüşünde. Şehnâme-i Mehmed Hân, 1598, TSMK H $1609,68 \mathrm{~b}-69 \mathrm{a}$.
Fetvac1, Picturing History, 258-63. Bu resmin bu sırada İstanbul'da bulunan Safavi elçi heyeti ve bu dönemde Osmanl1-Safavi dünyaları arasındaki kültürel alışveriş açısından bir değerlendirmesi için, Sinem Arcak, "Gifts in Motion: Ottoman-Safavid Cultural Exchange, 1501-1618" (doktora tezi, University of Minnesota, 2012), 208-214. Saray ressamlarının hükümdarlığı süresince hiçbir şehir mekânında resmetmedikleri Sultan Süleyman, 1588 civarında tamamlanan Hünernâme'de sünnet alayı ile Atmeydanı'nda tasvir edilecekti. Bu resim de, Sûrnâme'de lll. Murad ve şehzadesini Atmeydanı sarayına giden alayda tasvir eden resimlerden mülhemdir; TSMK H 1524, 103b-104a; TSMK H 1344, 7a.

95 Talikizade, Şehnâme, 67b-72a; Selaniki, Târîh, 652-654.

96 Resim ve söz ilişkisi, görsel temsilin öznel boyutları burada bütünlüklü olarak yansıtamayacağım geniş bir literatürün konusu. Görsel ve sözel temsilin olanaklarını ve bunlara dair seçimleri estetik, tarihi, toplumsal ve siyasi boyutları ile de tartıșan W.J.T. Mitchell'in çalışmaları bu sorular için kavramsal bir çerçeve çizebilir: W.J.T. Mitchell, Picture Theory (Chicago: Chicago University Press, 1994), özellikle 111-183, 371-397; What Do Pictures Want? The Lives and Loves of Images (Chicago: Chicago University Press, 2005). Osmanl resmi 
Şekil 16: III. Murad Bab-1 Humayun'dan çıkarken. Nakşi Bey, Nadiri, Divan, 1605 veya sonras1, TSMK H 889, 4a.

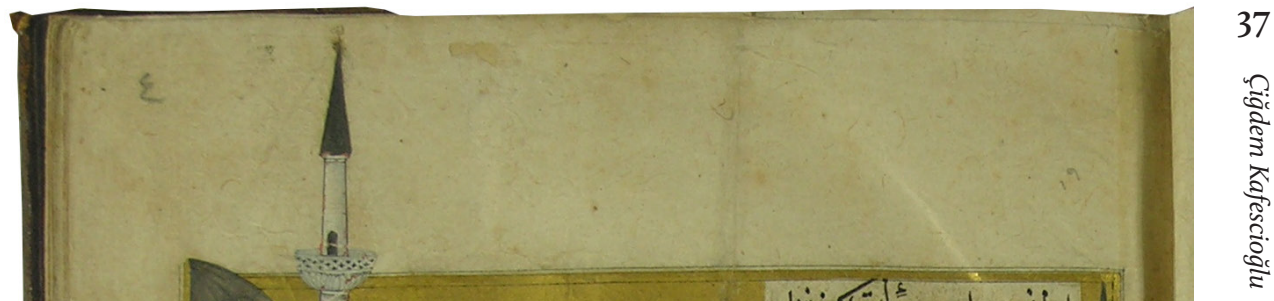

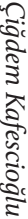

ve özellikle Sûrnâme bağlamında görsel dil ve resimsel yapıya dair iki ayrı tartışma için: Tansuğ, Şenlikname Düzeni; Tükel, "Atmeydanı'nda Bir Șenliğin Gösterimi.” Metin ve resim ilișkisine saray ve șehir arasındaki dinamikleri de ele alarak, görsel ve metinsel okuma pratikleri ve okuryazarlık açısından yaklaşan Tülün Değirmenci'nin çalıșmaları da biraz daha geç tarihli kaynaklara odaklanmakla birlikte burada sorduğum sorular açısından aydınlatıcı olabilir: Değirmenci, "An illustrated mecmua”; "Osmanlı Tasvir Sanatında Görselin 'Okunması."” 
sonra cereyan eden Kira Vakası'nın, Tuği'nin nefes kesen bir gerilimle aktardığı—ve sokağı, Ayasofya'yı, sarayı da içeren bir dizi mekânı anlatının kuvvetli odakları kıldığı-ll. Osman Vakası'nın, Çınar Vakası'nın bu döneme ait anlatıları arasında bize ulaşan hiçbir görsel imge yoktur. Bu yokluğu, dönemin Osmanlı dünyasında görsel temsilin ağırlıklı olarak seçkinlere has bir alan olduğunu ve seçkinlerin şiddetin şehrî halinin resmedilmesinden hazzetmediklerini düşünerek mi okumak gerekir? Bu soruya hem evet hem hayır diye cevap verilebilir. Bu konjonktürde ortaya çıkan yeni mekân ve görsellik inşası, resimleri ve ait oldukları kitapları şekillendirir. Sipahiyi, yeniçeriyi ve şehirlileri sokağa çıkartan vakalar resmin konusu olmaz, diğer taraftan Sûrnâme metni ve resimleri, Hünernâme'nin çok perspektifli şehir haritası ve başka kitaplar çok sesli ve diyalojik yapıları ile şehirlilerin seslerini ve bakışlarını barındırırlar.

Hükümdarlığının son senelerinde saray kapısından dışarı adım atmayan III. Murad'ı ölümünden en az on sene, belki daha uzun süre sonra, Bab-1 Humayun'dan çıkarken, bir grup şehirli ile karşı karşıya resmeden Nakşi Bey de böyle bir çok sesliliğin-üstelik muzipanlatıcılarından biridir kanımca (şek. 16). ${ }^{97}$ Nakşìnin resmettiği saray kapısı, yani üzerindeki sultan kasrı ile Bab-ı Hümayun, her şeyi görmeye kadir hükümdarın varlığını ve iktidarını imlemek üzere yüz yıldan uzun bir zaman önce, $1470^{\prime}$ lerde tasarlanmış ve inşa edilmişti..$^{8}$ Nakşi'nin resminde, saray kapısının hemen dışında mimari bir simge aracılı̆̆ı ile değil bedeni varlığı ile temsil edilen IIl. Murad'ı görürüz. Karşısında aralarında bir derviş, bir Frenk ve başka bir Hristiyan, baldırı çıplak urgan kuşaklı biri, atları ve kıymetli kumaşlardan kaftanlarıyla herhalde zengin tüccarlar, belki aşağılık telakki edilen meslekleri dolayısıyla diğerlerinden daha küçük ölçekte resmedilmiş bir dilenci ve bir yankesici de bulunan, bazıları arz-1 hallerini sultana doğru uzatan şehirliler vardır. ${ }^{99}$ Padișahın bu kişilerle paylaștı̆̆g yer, gergin ve talepkâr kalabalıkların bu senelerde sık sık toplandıkları, divan üyelerinin karşısına çıktıkları ve onlarla müzakerelere giriştikleri alanlardan biridir-ve Bab-1 Hümayun'dan çıkış anını tasvir eden başka resimlerin tam bu senelerde Osmanlı tarih yazmalarına girmesi muhtemelen tesadüfi değildir. Nakşi, Sultan Murad'ı saray kapısının dışına çıkarken gösterip, hemen karşısına da şehirlileri yerleştirirken, dönüşmekte olan bir hükümdarlık tahayyülünü ve mekân aracıllı̆ıyla ifade edilen talepleri resmeder. Erken modern dönem İstanbul'unda mekânın ve görselliğin tarihini karş1-görselliğin, çok sesliliğin ve bakma hakkının tarihi ile birlikte yazabilmemiz için bize bir ipucu bırakır.

97 Nâdiri, Dîvân, TSMK H 889, 4a. Ressam Nakși Bey için bkz. Süheyl Ünver, Ressam Nakși: Hayatı ve Eserleri (İstanbul: İstanbul Üniversitesi, 1949); Esin Atıl, "Ahmed Nakși: An Eclectic Painter of the Early $17^{\text {th }}$ Century," Fifth International Congress of Turkish Art, der. Geza Feher (Budapeşte: Akadémia Kiadó, 1978), 103-122; Bağc1, Osmanlı Resim Sanatı, 210-21. Nâdiri divanı ve Nakşi resimlerinin ve bu resmin, görsel ve edebi temsil ilişkileri açısından bir yorumu için bkz. Değirmenci, "Şiirin resmi: Nâdirînnin kasideleri, Nakş̂̂nin tasvirleri," Kaside’ye Medhiye, der. Hatice Aynur et al. (İstanbul: Klasik, 2013), 315-337. Değirmenci, Nakşi'nin Nadiri'nin III. Murad için yazdığı kasidede bulunan bayram temasına atfen sultanı bayram namazına giderken resmettiğini öneriyor; Murad'ın saray merkezli hayatı ile bu imge arasındaki tezata dikkat çekiyor.

98 Necipoğlu, 15. ve 16. Yüzyllda Topkapı Sarayl, 59-67; "Framing the Gaze," 304-306.

99 Mehmet İpşirli'nin dikkat çektiği 1550'ler ve 1570'ler tarihli anlatılar, halktan kişilerin Cuma selamlığı (padişahın Cuma namazı için camiye gidisi ve dönüsü) sırasında kendisine arz-1 hallerini iletmelerinin erken tarihli örneklerini olusturuyor; Mehmet İpsirli, "Cuma Selamlığı," Türkiye Diyanet Vakfı İslam Ansiklopedisi, c. 8 (İstanbul: Türkiye Diyanet Vakf1, 1993), 90-92. Bu âdete dair bu tarihlerden bize ulaşmış bir görsel belge yoktur. 
Birincil Kaynaklar

Başbakanlık Osmanlı Arşivi (BOA) BOA, Kamil Kepeci Defterleri (KK.d.)

İstanbul Üniversitesi Kütüphanesi (ï̈K) 'Abd al-Rahman al-Bistami. Tercüme-i Miftāḥ-ı Cifrü'l-Cāmi' . Çeviren Şerif bin Seyyid Mehmed ibn-i Seyyid Burhan. IÜK, T 6624. IÜK, T 6624.

Seyyid Lokman. Şehinşehnâme. Cilt 1. 1581. IÜK, F 1404.

Topkapı Sarayı Müzesi Arşivi (TSMA)

Topkapı Sarayı Müzesi Kütüphanesi (TSMK)

Firdevsi. Şehnâme. 1585. TSMK, H 1548.

Firdevsi. Şehname. 1580-85. TSMK, H 1475.

İntizami. Sûrnâme-i Humâyûn. 1588. TSMK, H 1344.

Nâdiri. Dîvân. TSMK, H 889.

Seyyid Lokman. Hünernâme. Cilt 1. 1585 civarı. TSMK, H 1523.

Seyyid Lokman. Hünernâme. Cilt 2. 1588 civarı. TSMK, H 1524.

- Şehinşehnâme. Cilt 2. 1592. TSMK, B 200.

Talikizade. Şehnâme-i Mehmed Hân. 1598. TSMK, H 1609.

—. Şemâilnâme. 1590. TSMK, A 3592.

Diğer Kütüphaneler

Atlas, Walters Art Museum, W 66o.

İntizami. Sûrnâme-i Humâyûn. 1584. Süleymaniye Kütüphanesi, Hekimoğlu 642.

Sadi. Bustân. 1488. Kahire Milli Kütüphanesi, Adab Farsi 908.

Safi. Şehrengîz. 1537-1538. Nuruosmaniye Kütüphanesi 3383.

Seyyid Lokman. Zafernâme. 1578. Dublin Chester Beatty Library T 413.

Su'ûdi. Matâli ‘ü's-sa'âde ve yenâbi ü’s-siyâde. 1582. Bibliothque nationale de France, Turc 242.

\section{Basılmış Birincil Kaynaklar}

Ahteri Mustafa Efendi, Ahteri-i Kebir. Dersaadet: Matbaacı Kemal Efendi, 1324/1906-1907.

Evliya Çelebi. Evliya Çelebi Seyahatnamesi. 1. Kitap. Hazırlayan R. Dankoff et al. İstanbul: Yapı Kredi, 2006.

Hasan Bey-zâde Ahmed Paşa. Hasan Bey-zâde Tarîhi. Hazırlayan Şevki Nezihi Aykut. Ankara, Türk Tarih Kurumu, 2004.

Küçük Abdal. Otman Baba Velayetnamesi (Tenkitli Metin). Hazırlayan Filiz Kıllı̧, Mustafa Arslan, Tuncay Bülbül. Ankara: Grafiker, 2007.

Lami‘izade Abdullah Çelebi (d. 1531), Latifeler. Hazırlayan Yaşar Çalışkan. Ankara: Milli Eğitim Bakanlığı, 1994.

Mustafa Âli. "Câmi'u'l-buhûr der mecâlis-i sûr." Türk Edebiyatında Manzum Sûrnâmeler, hazırlayan Mehmet Arslan, 333-623. Ankara: Atatürk Kültür Merkezi Başkanlığı, 1999. - Dîvân. Hazırlayan İ. Hakkı Aksoyak. Cambridge: Harvard University, 2006.

—. Künhü’l-Ahbâr. Dördüncü Rükn: Osmanlı Tarihi. Ankara: Türk Tarih Kurumu, 2009.

—. Mevâidü’n Nefâis fî̀-Kavấidi'l-Mecâlis. Hazırlayan Mehmet Şeker. Ankara: Türk Tarih Kurumu, 1997.

Mütercim Asım Efendi. Burhân-ı Katı. Hazırlayan Mürsel Öztürk ve Derya Örs. Ankara: Türk Dil Kurumu, 2000.

Nâbî. "Nâbî Sûrnâmesi." Türk Edebiyatında Manzum Sûrnâmeler, hazırlayan Mehmet Arslan, 627-684. Ankara: Atatürk Kültür Merkezi Başkanlığı, 1999.

Nasuhü’s-Silahi. Beyān-ı Menāzil-i Sefer-i 'Irakeyn-i Sulțān Süleymān Hānn. Hazırlayan Hüseyin G. Yurdaydın. Ankara: Türk Tarih Kurumu, 1979.

Nev'izade Atayi. Sohbetü’l Ebkâr. Hazırlayan Muhammed Yelten. İstanbul: i.Ü. Edebiyat Fakültesi, 1998.

Sâfî. Hasbihâl-i Sâfî: İnceleme, Metin Tipkıbasım. Hazırlayan Hanife Dilek Batislam. İstanbul: Kitabevi, 2003.

Selânikî Mustafa Efendi. Târîh-i Selânikî. Hazırlayan Mehmet İpşirli. İstanbul: İstanbul Üniversitesi Edebiyat Fakültesi, 1989.

Sinan Çavuş. Süleymannâme: Târîh-i Feth-i Şikloş, Estergon ve Istol-Belgrad. Hazırlayan Tevfik Temelkuran. İstanbul: Tarihi Araştırmalar Vakfi, 1998.

Tursun Bey. Târîh-i Ebû̉l-Feth. Hazırlayan M. Tulum. İstanbul, Baha Matbaası, 1977.

Yunus Emre. Yunus Emre Divanı. Hazırlayan Mustafa Tatçı. Ankara, Kültür ve Turizm Bakanlığı, 199o1991. 
"Ahl al-nazar." Encyclopedia of Islam, Second Edition. Erişim tarihi 25 Kasım 2019. http://dx.doi. org/10.1163/1573-3912_islam_SIM_0384.

Akalay Tanınd, Zeren. "Nakkaş Hasan Paşa." Sanat 6 (1977):114-25.

al-Azmeh, Aziz. "Preamble." The Medieval History Journal 9 (2006): 17-36.

And, Metin. Kırk Gün Kırk Gece: Osmanlı Düğünleri, Şenlikleri, Geçit Alayları. İstanbul: Toprakbank, 2000.

- Osmanlı Şenliklerinde Türk Sanatları. Ankara: Kültür ve Turizm Bakanlı̆̆ı, 1982.

Andrews, Walter ve Mehmet Kalpakl. The Age of Beloveds: Love and the Beloved in Early-modern Ottoman and European Culture and Society. Durham: Duke University Press, 2005.

Antov, Nikolai. The Ottoman "Wild West": The Balkan Frontier in the Fifteenth and Sixteenth Centuries. New York: Cambridge University Press, 2017.

Arcak, Sinem. "Gifts in Motion: Ottoman-Safavid Cultural Exchange, 1501-1618." Doktora tezi, University of Minnesota, 2012.

Arslan, Mehmet. Osmanlı Saray Dügünleri ve Şenlikleri 2: Intizâmi Surnâmesi (Surnâme-i Humâyûn). İstanbul: Sarayburnu Kitaplı̆̆ı, 2009.

—. Türk Edebiyatında Manzum Sûrnâmeler. Ankara: Atatürk Kültür Merkezi Başkanlığı, 1999.

Artan, Tülay. "Forms and Forums of Expression: Istanbul and Beyond, 1600-18oo." The Ottoman World, derleyen Christine Woodhead, 378-406. New York: Routledge, 2012.

Atasoy, Nurhan. 1582 Surname-i Hümayun Dügün Kitabı. İstanbul: Koçbank, 1997.

Atıl, Esin. "Ahmed Nakşi: An Eclectic Painter of the Early $17^{\text {th }}$ Century." Fifth International Congress of Turkish Art, derleyen Geza Feher, 103-122. Budapeşte: Akadémia Kiadó, 1978.

Aytaç, Senem, Zeynep Dadak ve Berke Göl. "Kamera öncesi bir Kamera Gezisi: Cemal Kafadar ile söyleşi.” Altyazı Sinema Dergisi 109 (Eylül 2011): 48-55.

Babaie, Sussan ve Çiğdem Kafescioğlu. "Istanbul, Isfahan, and Delhi: Imperial Designs and Urban Experiences in the Early Modern Era (1450-1650)." A Companion to Islamic Art and Architecture, cilt 2, derleyen Gülru Necipoğlu ve F. Barry Flood, 846-873. Oxford: Blackwell, 2017.

Bağcı, Serpil, Filiz Çağman, Günsel Renda ve Zeren Tanındı. Osmanlı Resim Sanatı. Ankara: Kültür Bakanlığı, 2007.

Bağc1, Serpil. "Visualizing Power: Portraits of the Sultans in Illustrated Histories of the Ottoman Dynasty." Islamic Art 6 (2009): 113-127.

Bakhtin, Mikhail. The Dialogic Imagination. Four Essays. Çeviren Caryl Emerson ve Michael Holquist. Austin: University of Texas Press, 1981.

Ballon, Hilary ve David Friedman. "Portraying the City in Early Modern Europe: Measurement, Representation, and Planning." History of Cartography: Volume 3, Part 1, derleyen David Woodward, 680-704. Chicago: University of Chicago Press, 2007.

Batislam, Hanife Dilek. Hasbihâl-i Sâfî: Inceleme, Metin Tipkıbasım. İstanbul: Kitabevi, 2003.

Bryson, Norman. "Introduction: Art and Subjectivity." Looking In: The Art of Viewing, derleyen Mieke Bal, 1-39. Amsterdam: G+B Arts, 2001.

—. "The Gaze in the Expanded Field." Vision and Visuality (Discussions in Contemporary Culture), derleyen Hal Foster, 87-108. Seattle: Bay Press, 1988.

Çağman, Filiz. "Sultan Sencer ve Yaşı Kadın Minyatürlerinin Ikonografisi." Sanat Tarihinde Íkonografik Araştırmalar, Güner Inal'a Armağan Kitabı, 87-116. Ankara: Hacettepe Üniversitesi, 1993.

—. Osmanlı Sarayı Tasvir Sanatı. İstanbul: Masa, 2016.

Çavuşoğlu, Mehmed. "Zâtînin Letâyifi - II.” Türk Dili ve Edebiyatı Dergisi 22 (1976): 143-161.

de Certeau, Michel. The Practice of Everyday Life. Çeviren Steven Rendall. Berkeley: University of California Press, 1984.

Değirmenci, Tülün. "An illustrated Manuscript: The Commoner's Voice and the Iconography of the Court in Seventeenth-Century Ottoman painting.” Ars Orientalis 41 (2011): 186-218.

__. "Kahve Bahane Kahvehane Şahane: Bir Osmanlı Kahvehanesinin 'Portresi'.” Bir Taşım Keyif: Türk Kahvesinin 500 Yıllık Öyküsü, derleyen Ersu Pekin, 119-137. Ankara: Kültür ve Turizm Bakanlığı, 2015. - "Osmanlı Tasvir Sanatında Görselin "Okunması": İmgenin Ardındaki Hikâyeler (Şehir Oğlanları ve İstanbul'un Meşhur Kadınları).” Osmanlı Araştırmaları 45 (2015): 25-55.

—. "Şiirin Resmi: Nâdirînin Kasideleri, Nakş̂̀nnin Tasvirleri." Kaside’ye Medhiye, derleyen Hatice Aynur et al., 315-337. İstanbul: Klasik, 2013.

“Ehlünnazar," İslam Ansiklopedisi. Cilt 4, 208. İstanbul: Milli Ĕgitim Basımevi, 1950.

Emiralioğlu, Pınar. Geographic Knowledge and Imperial Culture in the Early Modern Ottoman Empire. Burlington: Ashgate, 2014.

Erdoğan İşkorkutan, Sinem. "The 1720 Imperial Festival in Istanbul: Festivity and Representation in the Early Eighteenth Century Ottoman Empire.” Doktora tezi, Boğaziçi Üniversitesi, 2017.

Faroqhi, Suraiya. "Research on Ottoman Festivities and Performances." Celebration, Entertainment and Theater in the Ottoman World, derleyen Suraiya Faroqhi ve Arzu Öztürkmen, 24-68. Londra: Seagull, 2014 .

- Artisans of Empire: Crafts and Craftspeople under the Ottomans. Londra: I.B. Tauris, 2009.

Fetvac1, Emine. "Love in the Album of Ahmed I." Journal of Turkish Studies 34 (2010): 37-52. . "The Gaze in the Album of Ahmed I." Muqarnas 32 (2015): 135-154. 
—. "The Office of the Ottoman Court Historian." Studies on Istanbul and Beyond: The Freely Papers. Volume 1, derleyen Robert G. Ousterhout, 7-21. Philadelphia: University of Pennsylvania Press, 2007.

- Picturing History at the Ottoman Court. Bloomington: Indiana University Press, 2013.

- The Album of the World Emperor: Cross Cultural Collecting and the Art of Album Making in Seventeenth-century Istanbul. Princeton: Princeton University Press, 2019.

Fleischer, Cornell. Tarihçi Mustafa Âli: Bir Osmanlı Aydın ve Bürokratı. Çeviren Ayla Ortaç. İstanbul: Tarih Vakfı Yurt Yayınları, 1996.

Foucault, Michel. Discipline and Punish: The Birth of the Prison. Çeviren Alan Sheridan. Londra: Penguin, 1991.

Gell, Alfred. Art and Agency: An Anthropological Theory. Oxford: Clarendon Press, 1998.

Ginzburg, Carlo. Myths, Emblems, and Clues. Çeviren J. Tedeschi ve A. Tedeschi. Londra: Hutchinson Radius, 1986.

Grabar, Oleg ve Mika Natif. “Two Safavid Miniatures: An Interpretation.” Muqarnas 18 (2001): 173-202.

Grabar, Oleg. Mostly Miniatures: An Introduction to Persian Painting. Princeton, Princeton University Press, 2000.

Hamadeh, Shirine. Şehr-i Sefa: 18. Yüzyılda İstanbul. Çeviren İlknur Güzel. İstanbul: İletişim, 2010.

İnalcık, Halil. "Dervish and Sultan: An Analysis of the Otman Baba Velayetnamesi." The Middle East and the Balkans under the Ottoman Empire: Essays on Economy and Society. Bloomington: Indiana University Turkish Studies, 1993.

İpşirli, Mehmet. "Cuma Selamlığı." Türkiye Diyanet Vakfı İslam Ansiklopedisi. Cilt 8, 90-92. İstanbul: isAM, 1993.

Jaeckel, Ralph. “Dukaginzade Taşlıcalı Yahya Bey's King and Beggar: A Sixteenth Century Ottoman Allegorical-Mystical Love Poem (Mesnevi)." Doktora tezi, UCLA, 1980.

Kafadar, Cemal. "Eremya Çelebi Kömürciyan'ın Kamera öncesi Kamerası." Altyazı Sinema Dergisi 150. Özel Sayı: Altyazı'nın Gayrı Resmi ve Resimli Türkiye Sinema Sözlüğü (Haziran-Eylül 2015): 78-79.

—. "How dark is the history of the night, how black the story of coffee, how bitter the tale of love: The changing measure of leisure and pleasure in early modern Istanbul." Medieval and Early Modern Performance in the Eastern Mediterranean, derleyen Arzu Öztürkmen ve E. Birge Vitz, 243269. Turnhout: Brepols, 2016.

—. "Janissaries and Other Riffraff of Ottoman Istanbul: Rebels without a Cause?" Identity and Identity Formation in the Ottoman World, derleyen Karl K. Barbir and Baki Tezcan, 113-134. Madison,Wisconsin: Center for Turkish Studies, 2008.

. "The Question of Ottoman Decline." Harvard Middle Eastern and Islamic Review 1-2 (1997-1998): 30-75.

Kafescioğlu, Çiğdem. "Görsel Sanatlar.” Türkiye Tarihi 1453-1603, cilt 2, derleyen Suraiya Faroqhi, Kate Fleet, çeviren Egemen Özkan, 551-652. İstanbul, Kitap Yayınevi, 2016.

_. "Viewing, Walking, Mapping Istanbul, ca. 1580." Mitteilungen des Kunsthistorischen Institutes in Florenz LVI, Heft 1 (2014): 16-35.

-Constantinopolis/Istanbul. Cultural Encounter, Imperial Vision, and the Construction of the Ottoman Capital. University Park: Pennsylvania State University, 2009.

Kanar, Mehmet. Eski Anadolu Türkçesi Sözlüğü. İstanbul: Say, 2011.

Karacasu, Barış. “Türk Edebiyatında Şehr-engîzler.” Türkiye Araştırmaları Literatür Dergisi 5 (2007): 259313.

Karateke, Hakan. "On the Tranquility and Repose of the Sultan': The Construction of a Topos.” The Ottoman World, derleyen Christine Woodhead, 116-129. New York: Routledge, 2012.

Keene, Derek. "Cities and Cultural Exchange." Cities and Cultural Exchange in Europe 1400-1700, Cultural Exchange in Early Modern Europe, cilt 2, derleyen Donatella Calabi ve Stephen Turk Christensen, 3-27. Cambridge: Cambridge University Press, 2007.

Keyvani, Mehdi. "Artisans and Guild Life in the Later Safavid Period." Doktora tezi, Durham University, 1980.

Kim, Sooyong. The Last of an Age: The Making and Unmaking of a Sixteenth-century Ottoman Poet. Londra: Routledge, 2018.

Kuru, Selim S. "Naming the Beloved in Ottoman Turkish Gazel: The Case of İshak Çelebi (d. 1537/8)." Ghazal as World Literature II. From a Literary Genre to a Great Tradition: The Ottoman Gazel in Context, derleyen Angelika Neuwirth et al., 168-172. Würzburg: Ergon Verlag, 2006.

Kütükoğlu, Mübahat. "Ayak divanı.” Türkiye Diyanet Vakfı İslam Ansiklopedisi. Cilt 4, 192-193. İstanbul: isAM, 1991.

Latour, Bruno. "From Realpolitik to Dingpolitik or How to Make Things Public." Making Things Public: Atmospheres of Democracy, derleyen Bruno Latour ve Peter Wibel, 14-43. Cambridge, MA: MIT, 2005.

Lelic, Emin. “Ottoman Physiognomy ('Ilm-i Firâset): A Window into the Soul of an Empire.” Doktora tezi, Chicago Üniversitesi, 2017.

Levend, Agah Sırrı. Türk Edebiyatında Şehr-engizler ve Şehr-engizlerde İstanbul. Istanbul: Fetih Derneği, 1958. 
Meninski, Franciszek. Thesaurus linguarum orientalium Turcico-Arabico-Persicae: Lexicon TurcicoArabico-Percicum. Derleyen Stanislaw Stachowski. İstanbul, Simurg, 2000.

Mirzoeff, Nicholas. The Right to Look: A Counterhistory of Visuality. Durham: Duke University Press, 2011.

Mitchell, W. J. Thomas. Picture Theory. Chicago: Chicago University Press, 1994.

-What Do Pictures Want? The Lives and Loves of Images. Chicago: Chicago University Press, 2005.

Müller-Wiener, Wolfgang. İstanbul'un Tarihsel Topografyast: 17. Yüzyll Başına kadar ByzantionKonstantinopolis Istanbul. Çeviren Ülker Sayın. İstanbul: Yap1 Kredi Yayınları, 2002.

Mulvey, Laura. "Visual Pleasure and Narrative Cinema." Screen 16, s. 3 (Sonbahar 1975): 6-18.

Necipoğlu, Gülru. "Framing the Gaze in Ottoman, Safavid, and Mughal Palaces." Ars Orientalis 23 (1993):303-342.

—_. "The Scrutinizing Gaze in the Aesthetics of Islamic Visual Cultures: Sight, Insight, and Desire." Muqarnas 32 (2015): 24-61.

—. 15. ve 16. Yüzyılda Topkapı Sarayl: Mimari, Tören ve İktidar. Çeviren Ruşen Sezer. İstanbul: Yapı Kredi, 2014.

—. Sinan Çağı: Osmanlı Imparatorluğunda Mimarî Kültür. Çeviren Gül Çağalı Güven. İstanbul: Bilgi Üniversitesi, 2013.

Nuti, Lucia. "The Perspective Plan in the Sixteenth Century: The Invention of a Representational Language.” The Art Bulletin 76 (1994): 105-128.

Nutku, Özdemir. "Atmeydanı'nda Düzenlenen Şenlikler." Hippodrom/Atmeydanı: Istanbul'un Tarih Sahnesi / Hippodrome/Atmeydanı: A Stage for Istanbul's History. Cilt 2, derleyen Ekrem Işın, 71-95. İstanbul: Pera Müzesi, 2010.

Orbay, Iffet. "Istanbul Viewed: The Representation of the City in Ottoman Maps of the Sixteenth and Seventeenth Centuries." Doktora tezi, Massachusetts Institute of Technology, 2001.

Özergin, M. Kemal. "Letâif-i Esnaf.” Türk Folklor Araştırmaları Dergisi 209 (Aralık 1966): 4276-78.

__. "Letâif-i Esnâf'dan, I: Etmekci.” Türk Folklor Araştırmaları Dergisi 254 (Eylül 1970): 5742-5744.

Pitarakis, Brigitte ve Ekrem Işın, derleyen Hippodrom/Atmeydant: İstanbul'un Tarih Sahnesi /Hippodrome/ Atmeydanı: A Stage for Istanbul's History. 2 cilt. Istanbul: Pera Müzesi, 2010.

Procházka-Eisl, Gisela. "Guild Parades in Ottoman Literature: The Sûrnâme of 1582." Crafts and Craftsmen of the Middle East: Fashioning the Individual in the Muslim Mediterranean, derleyen Suraiya Faroqhi ve Randi Deguilhem, 41-54. Londra: I.B. Tauris, 2005.

—. Das Sūrnāme-i Humāyūn. Der Wiener Handschrift in Transkription, mit Kommentar und Indices versehen. İstanbul: Isis Verlag, 1995.

Roberts, Sean. Printing a Mediterranean World: Florence, Constantinople, and the Renaissance of Geography. Cambridge, MA: Harvard, 2013.

Şahin, Kaya. "Staging an Empire: An Ottoman Circumcision Ceremony as Cultural Performance." The American Historical Review 123 (2018): 463-492.

Schulz, Juergen. "Jacopo de' Barbari's View of Venice: Map Making, City Views, and Moralized Geography before the Year 1500." Art Bulletin 6o, s. 3 (1978): 425-474.

Sharma, Sunil. "Generic Innovation on Sayfi Buhara'i's Shahrashub ghazals." Ghazal as World Literature II. From a Literary Genre to a Great Tradition: The Ottoman Gazel in Context, derleyen Angelika Neuwirth et al., 141-152. Würzburg: Ergon Verlag, 2006.

Sims, Eleanor, Boris Marshak ve Ernst J. Grube. Peerless Images: Persian Painting and Its Sources. New Haven: Yale University Press, 2002.

Stout, Robert E. "The Sûr-i Hümâyun of Murad III: A Study of Ottoman Pageantry and Entertainment.” Doktora tezi, Ohio State University, 1966.

Sturken, Marita ve Lisa Cartwright. Practices of Looking: An Introduction to Visual Culture. New York: Oxford University Press, 2004.

Tansuğ, Sezer. Şenlikname Düzeni. İstanbul: Everest, 2018.

Terzioğlu, Derin. “The Imperial Circumcision Festival of 1582: An Interpretation.” Muqarnas 12 (1995): 84-10o.

Tezcan, Baki. The Second Ottoman Empire: Political and Social Transformation in the Early Modern World. New York: Cambridge University Press, 2010.

Tulum, Mertol. Meninskinin Thesaurus'u ve XVII. Yüzyll İstanbul Türkçesi. Ankara, Türk Dil Kurumu, 2011.

Tükel, Uşun. "Atmeydanında Bir Şenliğin Gösterimi: Klasik Dönem Osmanlı Minyatürünün Resim Dili." Hippodrom/Atmeydant: Istanbul'un Tarih Sahnesi / Hippodrome/Atmeydant: A Stage for Istanbul's History. Cilt 2, derleyen Ekrem Işın, 96-110. İstanbul: Pera Müzesi, 2010.

_. "Beyan-ı Menazil' in Resim Dili: Bir Yapısal Çözümleme." Doktora tezi, İstanbul Üniversitesi, 1990.

- "Beyan-ı Menazil'in Resim Dili Üzerine bir Anlamlandırma Denemesi.” Türk Kültüründe Sanat ve Mimari: Klasik Dönem Sanatı ve Mimarlığı Üzerine Denemeler, derleyen Mehmet Saçlıoğlu ve Gülsün Tanyeli, 190-206. İstanbul: 21. Yüzyıl Eğitim ve Kültür Vakfı, 1993.

Uluç, Lale. Türkmen Valiler, Şirazlı Ustalar, Osmanlı Okurlar: 16. Yüzyıl Şiraz Elyazmaları. İstanbul: İş Bankası, 2006. 
Ünver, Süheyl. Ressam Nakşi: Hayatı ve Eserleri. İstanbul: İstanbul Üniversitesi, 1949.

Vanhaelen, Angela ve Joseph P. Ward, derleyen Making Space Public in Early Modern Europe: Performance, Geography, Privacy. Londra: Routledge, 2013.

Wilson, Bronwen ve Paul Yachnin, derleyen Making Publics in Early Modern Europe: People, Things, Forms of Knowledge. New York: Routledge, 2011.

Woodhead, Christine. "Murad III and the Historians: Representations of Ottoman Imperial Authority in Late 16th-century Historiography." Legitimizing the Order: The Ottoman Rhetoric of State Power, derleyen Hakan T. Karateke ve Maurus Reinkowski, 85-98. Leiden: Brill, 2005.

- "Ottoman Historiography on the Hungarian Campaigns: 1596 Eger Fethnamesi." Proceedings of the VII. CIEPO Symposium, 469-477. Ankara: Türk Tarih Kurumu, 1994.

Yachnin, Paul ve Marlene Eberhart, derleyen Forms of Association: Making Publics in Early Modern Europe. Amherst: University of Massachusetts Press, 2015

Yelçe, Zeynep. "Evaluating three imperial festivals: 1524, 1530, 1539." Celebration, Entertainment and Theater in the Ottoman World, derleyen Suraiya Faroqhi ve Arzu Öztürkmen, 71-109. Londra: New York: Seagull, 2014.

Yi, Eunjeong. "Artisans' Networks and Revolt in Late Seventeenth-Century Istanbul: An Examination of the Istanbul Artisans' Rebellion of 1688." Popular Protest and Political Participation in the Ottoman Empire. Studies in Honor of Suraiya Faroqhi, derleyen Eleni Gara et al., 105-124. İstanbul: Bilgi University Press, 2011.

—. Guild Dynamics in Seventeenth-century Istanbul, Fluidity and Leverage. Leiden: Brill, 2004.

Yılmaz Diko, Gülay. "Blurred Boundaries between Soldiers and Civilians: Artisan Janissaries in Seventeenth-Century Istanbul." Bread from the Lion's Mouth: Artisans Struggling for a Living in Ottoman Cities, derleyen Suraiya Faroqhi, 175-193. Ohio: Ohio University Press, 2009.

Yılmaz, Gülay. "The Economic and Social Roles of Janissaries in a Seventeenth-Century Ottoman City: The Case of Istanbul." Doktora tezi, McGill University, 2011.

- "Urban Protests, Rebellions and Revolts." Companion to Early Modern Istanbul, derleyen Shirine Hamadeh ve Çiğdem Kafescioğlu. Leiden: Brill, 2020'de yayımlanacak. 